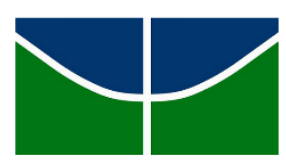

\author{
Universidade de Brasília \\ Instituto de Psicologia
}

Programa de Pós-Graduação em Psicologia Social, do Trabalho e das Organizações

\title{
"Eles querem nos converter" - Representações sociais sobre a minoria ativa vegan
}

Brasília, DF 
Universidade de Brasília

Instituto de Psicologia

Programa de Pós-Graduação em Psicologia Social, do Trabalho e das Organizações

“Eles querem nos converter" - Representações sociais sobre a minoria ativa vegan

Luiz Otávio Bastos Esteves

Brasília, DF 
Esteves, Luiz Otávio Bastos.

"Eles querem nos converter" - Representações sociais sobre a minoria ativa vegan / Luiz Otávio Bastos Esteves - 2017. $140 \mathrm{f}$.

Dissertação (mestrado) - Universidade de Brasília, Departamento de Psicologia, 2017.

Orientadora: Prof. a Dra. Ana Lúcia Galinkin

1. Representações sociais. 2. Minorias ativas. 3. Veganismo. 4. Movimentos sociais. 5. Estilo de vida. I. Galinkin, Ana Lúcia. II. Universidade de Brasília. Departamento de Psicologia. III. Título. 
Universidade de Brasília

Instituto de Psicologia

Programa de Pós-Graduação em Psicologia Social, do Trabalho e das Organizações

"Eles querem nos converter" - Representações sociais sobre a minoria ativa vegan

Luiz Otávio Bastos Esteves

Dissertação apresentada ao Programa de PósGraduação em Psicologia Social, do Trabalho e das Organizações, como requisito à obtenção do grau de Mestre em Psicologia Social do Trabalho e das Organizações.

Orientadora: Prof. ${ }^{\text {a }}$ Dra. Ana Lúcia Galinkin

Brasília, DF 
"Eles querem nos converter" - Representações sociais sobre a minoria ativa vegan

Dissertação defendida e aprovada pela banca examinadora constituída por:

Professora Doutora Ana Lúcia Galinkin (Presidente)

Programa de Pós-Graduação em Psicologia Social, do Trabalho e das Organizações

Universidade de Brasília

Professor Doutor Emílio Peres Facas (Membro)

Programa de Pós-Graduação em Psicologia Social, do Trabalho e das Organizações

Universidade de Brasília

Professora Doutora Luiza Monica de Assis da Silva (Membro)

Universidade Católica de Brasília - Programa de Comunicação Social

Professora Doutora Maria das Graças Torres da Paz (Suplente)

Programa de Pós-Graduação em Psicologia Social, do Trabalho e das Organizações

Universidade de Brasília 
“[...]e da pedra que se fez estrela ao aventurar-se a voar, resta a lição: o fogo queima...mas ensina a brilhar."

- Luiz Otávio Bastos Esteves 
Dedicatória

Ao meu avô Paulo que partiu durante essa minha aventura.

À minha mãe, Célia, por ser uma lição de vida sobre superação e coragem. 


\section{Agradecimentos}

Há dez anos eu fiz uma promessa. Há três, deixei o coração a mil quilômetros de mim com a lembrança das palavras que nunca mais pude ouvir de minha mãe: "o que aprendemos ninguém é capaz de roubar, é nosso para sempre”, ela dizia. Vim aprender em Brasília, com lágrimas sufocando a garganta e a esperança de trilhar o sonho da vida acadêmica. Encontrei tantas belezas e corações gigantescos nesse lugar que me abraçou como eu não conhecia ser possível. Não é possível fazer jus a todos, mas fica aqui minha gratidão.

Primeiro, agradeço ao amigo Daniel Kirjner por aquela passagem de ônibus em 2007 que me fez apaixonar pela cidade de Brasília, pelo primeiro teto que morei por aqui e pelo veganismo, que gerou tudo isso. À querida, parceira, salva-vidas, luz no fim do túnel, cúmplice e anjo-da-guarda, Luciana Tavares, por ser o melhor ser humano que eu conheci até hoje, pelo apoio mais do que fundamental, por todos os segundos vividos contigo. Aos amigos e amigas, Luana Carneiro, Filipe Lima, Luísa Gomes, Emerson "Maisena” Barros e Eduardo "Matosão" Lourenço, que me impediram, mesmo sem querer ou saber, de desistir tantas e tantas vezes que senti que não conseguiria suportar esse caminho, por tantas memórias incríveis que levarei comigo para sempre. Amo muito todos vocês!

Agradeço também, claro, à professora e orientadora Ana Lúcia Galinkin, por abraçar com tanta dedicação essas minhas ideias, por ser um exemplo para mim como profissional e como ser humano. Também aos colegas de grupo de pesquisa por todo o apoio e parceria!

Por último, mas jamais menos importante, ao Remela, o melhor ser vivo de todos os universos, meu melhor amigo e maior companheiro.

Acabou mais uma etapa. Agora faltam só todos os outros passos do resto dessa vida. Mãe, a promessa está cumprida! Manda vir mais que nada vai me derrubar. 


\section{Sumário}

Índice de tabelas..................................................................... xi

Índice de figuras....................................................................... xii

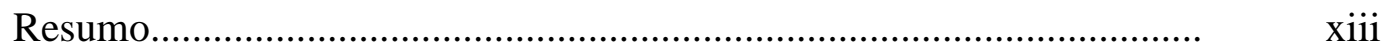

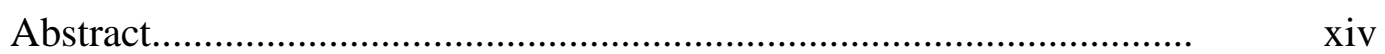

INTRODUÇÃO

Formação e Manutenção de Grupos Majoritários e Minoritários............. 3

Histórico dos Estudos Sobre Minorias nas Ciências Humanas................ 5

Teoria das minorias ativas - uma nova perspectiva................... 6

Representações Sociais - Acessando o Senso Comum da População.... 10

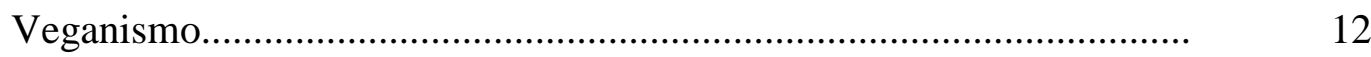

História, embasamentos, conflitos, contrastes e intersecções..... 13

Pré-história................................................................. 13

Da Antiguidade à Idade Média..................................... 14

Da Idade Moderna aos dias atuais................................ 15

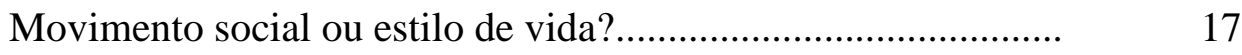

Ativismo vegano................................................................ 21

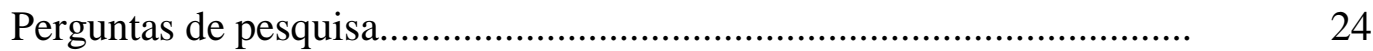

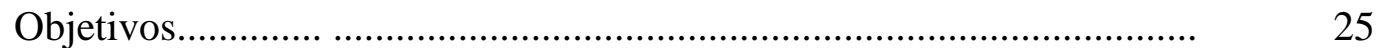

ESTUDO 1

"Amar independe de espécie": Autorrepresentações do movimento

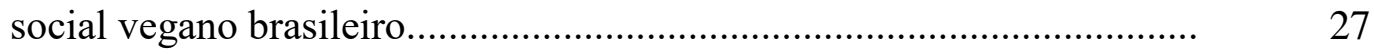

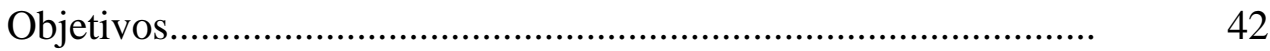

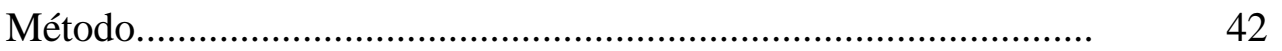




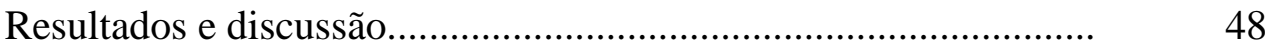

Considerações finais................................................................

\section{ESTUDO 2}

"Não podemos construir uma sociedade baseada no veganismo" -

Representações sociais do veganismo no Brasil...................................... 75

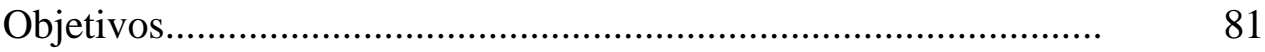

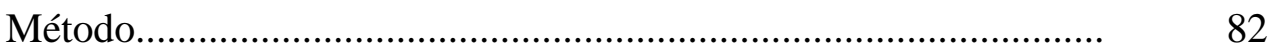

Resultados e discussão............................................................

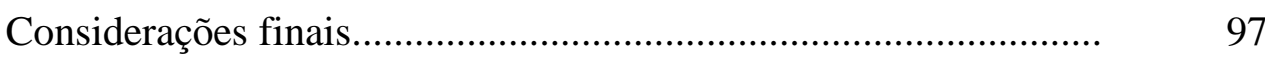

CONCLUSÃO

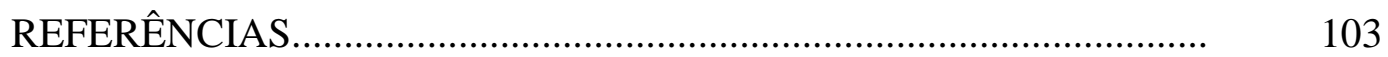

ANEXOS

ANEXO 1. Termo de Consentimento Livre e Esclarecido....................... 119

ANEXO 2. Questionários.............................................................. 120

ANEXO 3. Material discriminatório coletado durante a pesquisa............ 125 


\section{Índice de Tabelas}

Tabela 1 - Lista dos dez países com mais vegetarianos no mundo e suas respectivas porcentagens de veganos............................................. 2

Tabela 2 - Grau de escolaridade dos participantes................................

Tabela 3 - Renda dos participantes................................................... 49

Tabela 4 - Tempo de veganismo dos participantes............................... $\quad 50$

Tabela 5 - Respostas à escala Likert de 4 pontos sobre autoavaliação de ativismo.

Tabela 6 - Matriz de coocorrências dos termos evocados pelos participantes veganos.

Tabela 7 - Dendograma da CHD realizado com as justificativas dadas às evocações selecionadas pelos participantes veganos.

Tabela 8 - Dendograma da CHD do conteúdo do grupo focal.

Tabela 9 - Matriz de coocorrências dos termos evocados pelos participantes não veganos.

Tabela 10 - Dendograma da CHD realizado com as justificativas dadas às evocações selecionadas pelos participantes não veganos 


\section{Índice de Figuras}

Figura 1: Número absoluto e porcentagem relativa de participantes por sexo biológico.

Figura 2: Distribuição percentual dos participantes por faixa etária

Figura 3: Análise fatorial de correspondência das formas ativas no discurso de veganos na justificação da escolha do termo mais relevante no questionário de associação de palavras.

Figura 4: Análise fatorial de correspondência das formas ativas no discurso dos participantes do grupo focal.

Figura 5: Análise fatorial de correspondência das formas ativas no discurso de não veganos na justificação da escolha do termo mais relevante no questionário de associação de palavras. 


\section{Resumo}

O presente estudo buscou acessar, descrever e analisar as representações sociais construídas por veganos e não veganos acerca do veganismo. Além disso, buscou evidências de que este é um movimento social ativista, nos moldes da teoria das minorias ativas de Moscovici. O referencial teórico metodológico adotado foi a abordagem estrutural das representações sociais. Foi utilizado um instrumento de evocação, baseado na técnica de associação livre, tendo como termos indutores "ser vegano" e "veganismo". O instrumento apresentava-se dividido em duas partes: a primeira, para coleta dos dados sócio-demográfico dos participantes; e a segunda, para identificação das RS dos participantes. Além disso, 5 ativistas veganos participaram de um grupo focal visando aprofundar a compreensão das representações desse grupo. Os dados de 81 veganos e 79 não veganos foram analisados por meio do software Iramuteq (Interface de $R$ pour les Analyses Multidimensionnelles de Textes et de Questionnaires), versão 0.7 alpha 2. Os resultados sugerem que elementos de autotranscendência humana guiam o comportamento dos veganos na busca por um mundo de igualdade entre todas as espécies. Além disso, o aspecto ativista sociopolítico do veganismo encontra-se nas periferias da representação, sugerindo que este é um aspecto que só recentemente vem se tornando parte da representação do que é ser vegano para essa população. Para não veganos, os resultados sugerem que sua representação social é ancorada nas diferenças presentes nos hábitos alimentares dessas populações e que o contato entre elas é permeado por atitudes preconceituosas não hostis. Na zona de transformação pode-se observar alguns elementos de avaliação positiva, indicando construção recente. Apesar disso, sugere-se que o veganismo ainda é compreendido globalmente mais como estilo de vida do que como um movimento social.

Palavras-chave: Representações sociais; minorias ativas; veganismo; movimentos sociais; estilo de vida. 


\begin{abstract}
This study aimed at accessing, describing and analyzing the social representations (SR) built by vegans and non-vegans about veganism. In addition, it sought evidence that this is an activist social movement as per the active minority theory, by Moscovici. The theoretical methodology adopted was the structural approach of social representations and the focus group technique. An evocation instrument was used for data collection, based on the free association technique, using as inducing terms "being vegan" and "veganism". The instrument was presented in two parts: the first one collected the socio-demographic data of the participants; the second was used to identify the SRs of the participants. In addition, 5 vegan activists participated in a focus group that sought to produce further knowledge about the representations of this group. Data from 81 vegans and 79 non-vegans were analyzed using Iramuteq (Interface de $R$ pour les Analyses Multidimensionnelles de Textes et de Questionnaires), version 0.7 alpha 2. Results suggest that elements of human self-transcendence guide the behavior of vegans in pursuit of a world of equality between all species. In addition, the socio-political activist aspect of veganism is located at the peripheries of the representation, suggesting that this aspect has only recently become a fundamental part of what it means to be vegan for this population. For nonvegans, results suggest that their social representation is anchored on the differences between the food habits of these populations, and that their social experience is permeated by nonhostile prejudiced attitudes. On the transformation zone, some positive-evaluation elements were observed, suggesting that this is a recent construct. Besides that, the results suggest that veganism is still understood more as a lifestyle than a social movement.
\end{abstract}

Key words: Social representations; active minorities; veganism; social movement; lifestyle. 


\section{Introdução}

Acredita-se que a reunião dos conceitos e razões que fundamentam a postura ética, política e filosófica de abstenção e combate ao consumo e produção de produtos de origem animal (ou que praticam qualquer forma de crueldade contra animais), conhecida como veganismo, remonta à década de 1940, apesar de ser possível encontrar paralelos e rudimentos dessa ideologia em diversos momentos da história humana.

A organização moderna, ao redor do termo "vegan”, conferiu identidade aos seus praticantes. Ao organizarem-se em ONGs, e principalmente no ativismo cotidiano, os veganos puderam ser considerados um movimento social de defesa dos direitos animais e da preservação ambiental, focado na mudança de comportamento a partir da conscientização de outras pessoas e grupos. Diferentemente dos grupos ecoativistas, que defendem o progresso humano sustentável, o veganismo muitas vezes se coloca em oposição a isso, apontando os paradoxos no conceito de sustentabilidade.

Atualmente o Brasil, dentre os países já estudados, ocupa a sexta posição entre países com mais vegetarianos no mundo (Tabela 1) e a segunda posição do mundo em porcentagem relativa de veganos, com cerca de 16 milhões de vegetarianos (IBOPE, 2012), dos quais 28,6\% são veganos (Chaves, 2012), correspondendo a aproximadamente 5 milhões de indivíduos. Por sua fundamentação ideológica, pressupõe-se que indivíduos veganos enfrentam padrões culturalmente estabelecidos de consumo e produção para além da dieta vegetariana. Ao redor do mundo, a porcentagem de vegetarianos ainda é pequena, porém vem crescendo, principalmente nos países mais ricos (Radnitz, Beezhold, \& DiMatteo, 2015). Não há um só estudo centralizando a provável contagem de veganos no mundo, portanto, não há estimativa precisa de seu número. 
Tabela 1. Lista dos dez países com mais vegetarianos no mundo e suas respectivas porcentagens de veganos (quando disponível).

\begin{tabular}{|c|c|c|c|c|c|c|}
\hline País & $\begin{array}{l}\% \text { de } \\
\text { vegetarianos }\end{array}$ & $\begin{array}{l}\mathrm{N}^{\mathrm{o}} \mathrm{de} \\
\text { indivíduos } \\
\text { (aprox.) }\end{array}$ & $\begin{array}{l}\text { Ano de } \\
\text { censo }\end{array}$ & $\begin{array}{l}\% \text { de } \\
\text { veganos }\end{array}$ & $\begin{array}{l}\mathrm{N}^{\mathrm{o}} \mathrm{de} \\
\text { indivíduos } \\
\text { (aprox.) }\end{array}$ & $\begin{array}{l}\text { Ano de } \\
\text { censo }\end{array}$ \\
\hline Índia & $28,8 \%$ & 360.576 .000 & $2014^{(1)}$ & & & \\
\hline Israel & $13,0 \%$ & 1.046 .000 & $2015^{(2)}$ & $5 \%$ & 421.000 & $2015^{(2)}$ \\
\hline Austrália & $11.2 \%$ & 2.100 .000 & $2016^{(3)}$ & & & \\
\hline Suécia & $10,0 \%$ & 970.000 & $2014^{(4)}$ & $4 \%$ & 390.000 & $2014^{(4)}$ \\
\hline Áustria & $9,0 \%$ & 765.000 & $2013^{(5)}$ & & & \\
\hline Brasil & $8 \%$ & 16.000 .000 & $2012^{(6)}$ & $2,5 \%$ & 5.000 .000 & $2012^{(7)}$ \\
\hline Taiwan & $7,5 \%$ & 1.700 .000 & $2007^{(8)}$ & & & \\
\hline Itália & $7.1 \%$ & 4.246 .000 & $2015^{(9)}$ & $\begin{array}{l}0,6 \%- \\
2,8 \%\end{array}$ & $\begin{array}{l}400.000- \\
1.680 .000\end{array}$ & $2015^{(9)}$ \\
\hline Alemanha & $6-9 \%$ & $\begin{array}{l}4.786 .000- \\
7.000 .000\end{array}$ & $\begin{array}{l}2015^{(10)} \\
2013^{(11)}\end{array}$ & $1,0 \%$ & 800.000 & $2015^{(10)}$ \\
\hline Suíça & $5 \%$ & 375.000 & $2007^{(12)}$ & & & \\
\hline
\end{tabular}

(1) (The Times of India, 2014)

(2) (Cohen, 2015)

(3) (Morgan, 2016)

(4) (The Local/og, 2014)

(5) (Verein gegen tierfabriken, 2013)

(6) (IBOPE, 2012)

(7) (Chaves, 2012)

(8) (Cheng, 2007)

(9) (Schiavazzi, 2015)

(10) (Buech, 2015)

(11) (Redaktion, 2013)

(12) (Vegetarismus.ch, 2007) 
Posições de oposição cultural são histórica e conceitualmente associadas a ideais minoritários. O presente estudo pretende analisar o movimento social vegano brasileiro nos termos da teoria das minorias ativas como uma minoria nômica heterodoxa. Para alcançar esse propósito, um método analítico fundamentado na teoria das representações sociais será utilizado.

\section{Formação e Manutenção de Grupos Majoritários e Minoritários}

O pertencimento a grupos é um fator fundamental da identidade humana e gerador de conforto psicológico (Forsyth \& Burnette, 2010; Hornsey \& Jetten, 2004). Para que um indivíduo se sinta pertencente a um grupo, é necessário que ele consiga perceber-se semelhante às pessoas que compõem o grupo em questão e diferente das que não o compõem. Este processo é denominado categorização (Macrae \& Bodenhausen, 2000; Park \& Judd, 2005), o qual é responsável pelas percepções de homogeneidade do exogrupo e heterogeneidade do endogrupo. O aparente paradoxo é mais facilmente compreendido quando levamos em consideração a socialização como fator fundamental para a construção de critérios de avaliação de semelhança entre indivíduos. O convívio com semelhantes desde a primeira infância dá origem a processos de categorização e heurísticas que permitem ao indivíduo compreender o ambiente. Essa compreensão, de acordo com as teorias de cognição social, é limitada pela economia cognitiva (Fiske \& Taylor, 1984), onde o indivíduo dispõe de mecanismos de processamento de informação que estão sujeitos a limites, tanto na velocidade, quanto na quantidade de informações que é capaz de processar simultaneamente, uma vez que o ambiente social é composto por inúmeras unidades de informação e processá-las integralmente expandiria o tempo de reação dos indivíduos. Assim, para perceber-se participante de um grupo, o indivíduo compara seus valores, comportamentos, expectativas e posicionamentos com os das pessoas que pertencem ao grupo em questão, compondo-o, mas estabelecendo o limite 
desse pertencimento com base nas diferenças que exaltam sua individualidade - daí a heterogeneidade do endogrupo. O processo ocorre em relação ao exogrupo de forma inversa. Perceber-se parte de um grupo pressupõe que todos que não pertencem a ele são igualmente diferentes de si. A categorização é, assim, um processo fundamental para a formação da identidade que, por sua vez, existe nas diferenças. Em resumo, a identidade tem como propriedade fundamental o aspecto contrastivo, de oposição, de afirmação de um grupo por sua oposição a outro. O termo identidade compartilha significado com a palavra "idêntico" e a própria noção de alteridade pressupõe a existência de diferenças (Galinkin \& Zauli 2011).

Uma decorrência importante desse processo de categorização é o surgimento de atitudes preconceituosas (Park \& Judd, 2005), uma vez que a formação de heurísticas gera uma visão homogenista do corpo social, onde o posicionamento "nós vs. eles" se estabelece culturalmente como forma de manter e reforçar a identidade. O consenso ideológico é um fator importante na manutenção de grupos (Santos \& Almeida, 2005), porém, a natureza das dinâmicas relacionais predispõe a existência de diversos pontos de vista. Estruturas de poder construídas socialmente permitem que alguns subgrupos sejam subjugados por um aparente consenso, originando minorias - socialmente caracterizadas, entre outros elementos, pelos estigmas construídos pela maioria para diferenciá-las (Goffman, 1988).

Apesar de a definição veiculada em dicionários e aceita nas ciências sociais seja de que minorias são subgrupos de uma sociedade que se consideram, ou são considerados diferentes do grupo dominante por sua religião, etnia, nacionalidade, língua, ou posicionamento político e que, em decorrência disso, não têm a mesma participação na sociedade, nem as mesmas oportunidades, sofrendo, muitas vezes, discriminação e preconceito (Weiszflog, 2008), a interpretação dessa relação maioria-minoria como uma 
dinâmica de poder social não tem sido compartilhada adequadamente por instituições importantes para a inclusão social, como pode-se observar na definição adotada pela Organização das Nações Unidas (ONU) em sua Subcomissão para a Prevenção da Discriminação e a Proteção das Minorias:

Um grupo numericamente inferior ao resto da população de um Estado, em posição não dominante, cujos membros - sendo nacionais desse Estado possuem características étnicas, religiosas ou linguísticas diferentes das do resto da população e demonstre, pelo menos de maneira implícita, um sentido de solidariedade, dirigido à preservação de sua cultura, de suas tradições, religião ou língua (Capotorti, 1991, p. 26).

Há, portanto, para as agências responsáveis pelo estabelecimento de normas para proteção de minorias, bem como para toda as áreas da ciência humana, a urgência de ressignificação e disseminação do termo para além do senso numérico, uma vez que este atualmente extrapola o étnico, religioso ou linguístico.

\section{Histórico dos Estudos Sobre Minorias nas Ciências Humanas}

Tidos ora como subversivos e transgressores (Le Bon, 1895, 1897), ora como membros de um rebanho que pratica a mera reprodução de comportamentos (Tarde, 1890, 1901), ações de grupos minoritários estiveram no foco das publicações nas áreas da psicologia e sociologia durante parte do século XX, em concomitância com o contexto sociopolítico da época - Guerras Mundiais, Depressão de 1929, entre outros -, característico dessas áreas da ciência. Para os pesquisadores da época, o ativismo em prol de causas minoritárias se configurava num desvio de conduta, por vezes descrito como nocivo à ordem, onde o indivíduo desviante é posto em paralelo ao delinquente, sendo considerado intelectual e psicologicamente inferior aos demais (Moscovici, 1996). Esta perspectiva perdurou para além do início do século e foi adotada por 
diversas áreas das ciências sociais, comunicação e psicologia social, conforme pode ser visto em Jones e Gerard (1967), onde o termo "desvio de conduta" diz respeito àqueles comportamentos executados de maneira diferente do previsto pelo grupo ou pela cultura na qual se insere o indivíduo. Com essa perspectiva em mãos, é possível compreender as dificuldades que historicamente sofreram e sofrem movimentos sociais de minoria, tais como os movimentos feminista, LGBT, negro e suas intersecções (Duberman, 1991; Dunn \& Rowbotham, 1989; Haines, 1984). Há de ser levado em consideração que, apesar de antiga, a questão da discriminação de minorias, especialmente as cujas vertentes fundamentam suas ideologias na prática ativista, não se resolveu ainda e continua sendo tema de conflitos sociais. Assim, ainda nos dias atuais “o não conformismo e a marginalidade expõem os indivíduos às duras experiências do insulto, ao ostracismo e, inclusive, à perseguição pela defesa de uma crença, de um comportamento, de um setor do saber" (Moscovici, 1996, p. 50).

\section{Teoria das minorias ativas - uma nova perspectiva.}

Em meados da década de 1970, surgiu um contraponto a esse referente de desvio. À época, conforme supramencionado, os pesquisadores do tema consideravam o desvio advindo de minorias como delinquência, enquanto desvios no topo da escala social eram legitimados como inovação (Hollander, 1965; Jones \& Gerard, 1967; Secord \& Backman, 1974). O caráter socialmente aceitável do desvio de líderes fazia aparente uma realidade onde a mudança social era consequência da dominância, restando às minorias, portanto, o silêncio. Obviamente, não é isso que se observa empiricamente na sociedade. Assim, havia a necessidade urgente de se compreender qual a recompensa nestes esforços minoritários de mudança social - do contrário não haveriam tantas personalidades históricas capazes de afrontar pressões sociais até que mudanças ocorressem. 
Um contraste comum, dentro do raciocínio de "mudança pela dominância" era feito entre desvio como anomia - das minorias - e das ações decorrentes da independência e autonomia - dos líderes e grupos dominantes. O primeiro teria como característica marcante a transgressão das normas e da moral, motivada pela inferioridade psicológica e intelectual do ator. O segundo seria uma forma de resistência à conformidade, legitimada pelo prestígio social do indivíduo, assegurada pelo pressuposto de que ele aceitasse as normas e a moral, gozando de seu privilégio de escolher ignorá-las. Assim, da ironia presente na diferenciação entre desvio e autonomia/independência, baseada unicamente no "cumprimento desobediente" ou na "transgressão ignorante" das normas e resistência à conformidade, surgiu esta nova forma de interpretar as ações minoritárias, estabelecendo-se as bases da teoria das minorias ativas (Moscovici, 1976), posteriormente consolidada no livro Psicologia das Minorias Ativas (1996).

Nessa abordagem, conforme explica Del Prette (2012), os sistemas sociais e o ambiente são dinâmicos, ou seja, não preestabelecidos, nem predeterminados em relação ao indivíduo e ao grupo, conforme seria em uma perspectiva funcionalista da sociedade. Se fosse o caso, a participação - do indivíduo ou do grupo - se restringiria ao desempenho de papeis sociais definidos pelo status e recursos dos quais o indivíduo dispõe e que estão presentes nas interações sociais. Através dessas interações, “os papéis sociais, status e recursos psicológicos são compreendidos em sua dinâmica própria” (Del Prette, 2012). Dessa forma, a adaptação do indivíduo ao ambiente e a adaptação do ambiente ao indivíduo se complementam. O histórico dessa dinâmica gera as normas, ou seja, o resultado das relações presentes e passadas entre indivíduos e grupos determinaria as regras de conduta - e essa efemeridade da norma a faria passível de alterações, as quais não aconteceriam por acidente. Pelo contrário, seriam situações produzidas pelo próprio sistema social, indicando transgressão e evitação ao controle, 
um equilíbrio entre as estruturas de poder. Portanto, a influência social não necessariamente ocorreria em função da manutenção do sistema, mas também para que surjam melhores condições de vida e inserção de todos no corpo social a partir de alterações na organização da sociedade.

Essa perspectiva positiva na compreensão das ações de movimentos sociais deu início a um movimento de cessação do silenciamento sofrido historicamente pelos indivíduos que se identificam com ideologias minoritárias. Nessa visão, a manutenção do sistema social é uma forma de inovação, vista como um processo essencial da existência da sociedade, ao invés de uma forma de desvio (Mugny \& Papastamou, 1982). Ou seja, a inovação condicionaria a revisão das bases empíricas da construção social das normas, viabilizando a avaliação do processo de mudança, podendo ser originada de qualquer ponto da escala social.

Apesar de desvios estarem presentes em grupos compostos por indivíduos de qualquer status social, o estudo de Homans (1974) traz uma justificativa interessante para o ativismo de minorias. Contrastando consequências para indivíduos nos extremos da escala social, fica evidente que, para aqueles que possuem status social inferior, o desvio como forma de inovação derivada da não conformidade serve como uma aposta de ascensão. Isto é, ao adotar uma postura independente/autônoma, caso o resultado da ação seja positivo, a prova social servirá de alavanca para o reconhecimento do grupo e de seus ideais. Voltando, portanto, à questão da necessidade de se compreender a recompensa para os esforços de mudança social, Moscovici demonstra que "o não conformismo e a rebeldia contra a maioria oferecem algumas vantagens evidentes" (p. 53), como a integração ao corpo social. Diferentemente dos grupos/indivíduos dominantes, que tem em suas ações o risco da perda de crédito social (Hollander, 1965), as minorias marginalizadas supõem mais vantagens que riscos na empreitada de 
inserirem-se na sociedade. Assim, pretendendo subverter o mainstream de estudos sobre influência, como o de Asch (1951), que revolucionou a comunidade científica, apesar da clara tendência à depreciação das ações minoritárias, Moscovici promoveu a perspectiva de que processos de inovação e mudança social ocorreriam não obstantes às relações de status. Porém, haveria uma pressão de conformidade muito maior para os indivíduos do grupo majoritário do que àqueles das minorias e, portanto, caberia aos últimos o papel de agentes da transformação social.

A análise de Moscovici para a psicologia das minorias ativas propõe o modelo genético ou interacionista, estabelecendo que neste modelo, o sistema é definido e é resultado da ação de indivíduos que nele vivem e o confrontam. No processo de julgamento da legitimidade da mudança, o grupo alvo julga a consistência da reivindicação de mudança. Essa atribuição ocorre como resultado de influência. Estudos apontam que minorias com estilos comportamentais mais flexíveis foram percebidas como mais confiantes e competentes do que outras, mais rígidas (Moscovici \& Néve, 1973; Nemeth, Swedlund, \& Kanki, 1974), o que demonstra que a percepção de consistência depende da indicação de uma posição bem definida e elaborada, mais do que pela insistência em um posicionamento, inalterável com a mudança do estímulo.

Para Moscovici, as minorias e maiorias se classificam entre grupos nômicos e anômicos, sendo cada um ortodoxo ou heterodoxo. O caráter nômico de uma minoria refere-se à presença de normas ou respostas ao sistema social que sejam contrastantes ou opostos ao estabelecido. A anomia de uma minoria seria, portanto, caracterizada por respostas não organizadas de seus indivíduos, condicionadas pela ausência de normas e respostas próprias da identidade daquele grupo. A distinção de ortodoxia se refere à direção da divergência praticada por determinado grupo, ou seja, uma minoria ortodoxa é pró-normativa, enfatiza a norma majoritária, enquanto a minoria heterodoxa propõe 
resistência oferecendo normas minoritárias.

\section{Representações Sociais - Acessando o Senso Comum da População}

Para encontrar evidências de que o movimento social vegano se encaixa nos preceitos da teoria das minorias ativas, o método de escolha para a presente pesquisa foi o acesso às representações sociais - uma vez que o acesso às autorrepresentações podem revelar as formas pelas quais um grupo age socialmente, além das diversas transformações representacionais que estiverem ocorrendo em decorrência do contato social não hegemônico desse grupo.

Fundamentado no conceito de representações coletivas (Durkheim, 1898), onde o saber coletivo e as formas de consciência eram impostos culturalmente pela sociedade aos seus indivíduos, Moscovici também é autor de outra teoria que torna possível que pesquisadores acessem os construtos representativos criados para compreender os ideais de minorias - e, assim, caracterizá-las ou não como ativas -, bem como investigar a forma como ativistas percebem a marginalização que sofrem: a partir da perspectiva oferecida pela teoria das representações sociais (TRS). A diferença fundamental entre esta abordagem e a utilizada por Durkheim é que o saber coletivo é gerado pelos sujeitos sociais, ao invés da subjugação do indivíduo à ideia social imposta a ele.

Originada em seu trabalho seminal La psychanalyse, son image et son public (Moscovici, 1961), a TRS parte de uma perspectiva que busca compreender o ser humano, considerando-o como sujeito construído a partir de suas determinações evolutivas, históricas, culturais e sociais e que também é agente de sua própria realidade social. As representações sociais caracterizam-se como espaço de troca, ao mesmo tempo, em que as viabilizam. São definidas como um saber acerca do real que se estrutura na relação do sujeito com o objeto, mediada pelas interações com o outro. Ou seja, são construções e rearranjos cognitivos que permitem ao indivíduo explicar e 
compreender a realidade, justificando sua participação ou ausência em determinado contexto ou grupo. Dessa forma, representam um conjunto de saberes práticos criados a partir da interação com o outro (no sentido lato) que guiam a interpretação da realidade. Toda representação social é construída de forma que evite o conflito cognitivo. Portanto, a partir do contato com o outro, cada indivíduo absorve e transforma o conhecimento adquirido de forma a justificar e manter sua identidade individual ou grupal.

Para Moscovici, a assimilação desse conhecimento é sujeita a dois processos: objetivação e ancoragem. No primeiro, o conhecimento é transformado em imagens concretas por aproximação e reagrupamento de ideias e imagens que se enquadram no mesmo tema. Já no segundo, a imagem criada no primeiro processo é relacionada e comparada a conhecimentos prévios para que surja um conceito sobre o conhecimento que obedeça às necessidades do indivíduo para reforçar sua identidade individual ou grupal. Portanto, objetivação e ancoragem servem a função de tornar familiar o desconhecido e solucionar o conflito cognitivo do contato com o novo.

A expansão da TRS na forma de estudos posteriores evoluiu o raciocínio, conforme descritos em Sá (1998), que apresenta três desdobramentos importantes: o primeiro, proposto por Jodelet, intensificou a necessidade de descrever os fenômenos de representação social, caracterizando-os através dos discursos, comportamentos e práticas sociais dos grupos que conservam as representações. Essa proposta considerava os meios de comunicação e suas interpretações como agentes de conservação ou mudança das representações sociais.

O segundo, proposto por Doise, enfatiza a origem das representações sociais e seus meios de propagação. Nesta abordagem, a posição social do grupo é um dos fatores determinantes das representações sociais. Assim, haveria um condicionamento social que influenciaria tanto a formação como o conteúdo das representações sociais. 
O terceiro desdobramento, sustentado por Abric, é complementar à teoria iniciada por Moscovici, e é conhecida como a teoria do núcleo central, a qual propõe que as representações sociais possuem uma organização estrutural construída ao redor de um núcleo composto por elementos cognitivos mais estáveis, rígidos e consensuais e apresenta elementos individualizados, mutáveis e flexíveis em sua periferia. A teoria do núcleo central, portanto, postula que as representações se organizam ao redor de um núcleo central normativo, bastante rígido e perene - representativo das condições históricas do grupo, construído em função do sistema de normas em que se está inserido - e de sistemas periféricos funcionais, resultantes da experiência individual e que permitem que as representações sejam flexíveis e adaptáveis. É nos sistemas periféricos que se encontram os elementos de manutenção do núcleo central, ou seja, qualquer novo elemento que possa interferir na representação é avaliado e adaptado a partir dos sistemas periféricos, de forma a evitar que o núcleo central seja colocado em xeque.

A abordagem Estrutural (Abric, 1976), busca identificar a estrutura das representações sociais a partir da análise da evocação de palavras e de sua categorização. Esta análise viabiliza o reconhecimento dos elementos formadores, centrais e periféricos, das representações sociais. Com isso, é possível verificar a existência de um processo de transformação das representações sociais (FonteneleMourão, 2006).

Ao utilizar estas abordagens, é possível que o pesquisador acesse os construtos representativos criados para compreender as ideias de minorias. Assim, a partir da óptica oferecida por essas duas linhas de abordagem teórica - teoria das representações sociais e das minorias ativas -, o presente trabalho se propõe a investigar uma minoria ativa em especial: os veganos.

\section{Veganismo}


Vegan, termo originado em 1944 por um dos fundadores da British Vegan Society e que, segundo seu próprio autor, significa "o alfa e o ômega dos vegetarianos" (veg/etari/an) (Watson, 1965), denotando que devia ser a causa e a finalidade da opção pela abstenção do consumo de animais na dieta - muitas vezes motivada por determinação religiosa, por objetivos nutricionais e de saúde, ou por consciência ecológica. A ideologia vegana vai bastante além da adaptação dietária, uma vez que se fundamenta no vegetarianismo estrito (onde não há consumo de nenhum tipo de carne, laticínio, ovos, mel, corantes produzidos a partir de animais, gelatina, entre outros ingredientes de origem animal) e se combina ao buycott (Friedman, 1996) por abstenção do consumo dos produtos e serviços oferecidos pelo mercado que pratica exploração animal (cosméticos e medicamentos testados em animais, vestuário de couro, lã, seda e peles, transportes movidos por tração animal, entre outros). Ou seja, ao mesmo tempo em que é um tipo de dieta, o veganismo é uma filosofia de vida, uma postura ética e política e, por sua característica vinculativa ao abolicionismo animal, um ato de desobediência civil (Argolo, 2008).

\section{História, embasamentos, conflitos, contrastes e intersecções.}

Para compreender os princípios fundamentais dessa ideologia, é possível traçar uma linha de raciocínio que remonta à pré-história. A seguir, serão apresentadas cronologicamente algumas teorias fundamentais para o embasamento da ideologia vegana.

\section{Pré-história.}

Argumentos que acusam equívocos na teoria evolucionista humana em relação ao consumo pré-histórico de carne são escassos, mas podem ser encontrados em Spencer (1996), Hart \& Sussman (2005) e Phelps (2007) os quais apontam indícios de que espécies precursoras do Homo sapiens, contradizendo as teorias modernas do homem 
primitivo caçador, praticavam o vegetarianismo compulsório, à exceção de insetos, pequenos lagartos, ou moluscos terrestres que provavelmente serviam de alimento em situações de sobrevivência ou competição. Essa teoria perdura, uma vez que até a atualidade, nutricionistas argumentam que a encefalização dos hominídeos dependeu evolutivamente de uma proporção equilibrada entre os ácidos graxos ômega 3 e 6 , associados à dieta carnívora. Porém esses mesmos nutrientes podem ser encontrados em vegetais "verde-escuros" como brócolis, rúcula, couve, espinafre e em óleos vegetais, como o de soja, cânhamo, girassol, milho, entre outros. Além disso, a suposição de que a expansão cerebral súbita ocorrida na transição entre Australopithecus e Homo se deve à descoberta da atividade de pesca se baseia em análises arqueológicas pela identificação de restos de alimentos nos dentes de fósseis. De acordo com as teorias apresentadas, essa também pode ser uma suposição precipitada, uma vez que os traços desse tipo de alimentação permanecem mais evidentes e por mais tempo do que os de vegetais na dentição. Assim, ao rebater as teorias do homem primitivo caçador e da encefalização proveniente do consumo da carne de caça, veganos fundamentam a prática do veganismo no sentido em que desconstroem a predeterminação evolutiva ao consumo de produtos animais.

\section{Da Antiguidade à Idade Média}

Um salto no tempo nos leva à antiguidade Greco-Romana. À beira do Mar Mediterrâneo estavam estabelecidas as duas primeiras civilizações ocidentais eminentemente urbanas - grega e romana. Esses povos, essencialmente agricultores e, portanto, sedentários, consideravam "bárbaros" aqueles que não comiam o pão e nem bebessem do vinho, produtos culturais símbolos da civilização. O consumo de carne era reservado a situações ritualísticas, significando o sacrifício animal como meio para aproximar as pessoas dos antigos deuses pagãos. Quando não tinha fins religiosos, o 
consumo de carne era oriundo de caça, prática vista como uma atividade marginal no sistema de valores destas culturas (Flandrin, Montanari, Machado, \& Teixeira, 1998).

A filosofia da Idade Antiga também criticava o consumo de animais. Porfírio de Tiro, um filósofo neoplatônico, oriundo da região da Fenícia, é autor de um dos mais antigos tratados a favor do vegetarianismo que se tem notícia (Oliveira, 2013). Adepto do vegetarianismo como caminho para se aproximar do divino, registros deste filósofo encontrados no texto "Sobre a Abstinência" (Boyd, 1936) versam sobre a fundamentalidade da abstenção do consumo de animais pelos filósofos, pois isso os afastaria do contato com o divino - fundamental na busca pelo conhecimento. Para Porfírio, o consumo de animais deveria se restringir aos guerreiros e pessoas de menor capacidade intelectual.

No decorrer das eras, o consumo de carne acabou se tornando um símbolo de privilégio e riqueza. Após a queda dos grandes impérios do ocidente, a Idade Média trouxe consigo a dominação ideológica da Igreja Católica, o Feudalismo e as relações de suserania e vassalagem. Dentro dessa dinâmica, o consumo de carne pela plebe, quando permitido pela Igreja, era bastante restrito (Adamson, 2004; Carlin \& Rosenthal, 1998). Enquanto a fartura alimentar da Igreja era sustentada pelas doações de seus fiéis, alimentar-se de carne e oferecer aos seus convidados simbolizava poder e influência da nobreza, particularmente dos homens nobres. Esse significado ainda se mantém em diversas culturas, como por exemplo, no ritual do churrasco para sul-americanos (Tobin, 1999), estando portanto, relacionado a performances de gênero.

\section{Da Idade Moderna aos dias atuais}

A origem da crença no consumo de proteínas e produtos derivados de animais como base nutricional da dieta humana é, portanto, recente. A revolução industrial permitiu o crescimento exponencial do volume de produção das sociedades humanas. A 
mecanização do processo produtivo da indústria pecuária possibilitou excedentes de produção sem precedentes na história humana. No início da década de 1980, nos EUA, formou-se o Comitê de Informações Nutricionais Públicas [Public Nutrition Information Committee] composto por treze cientistas, designados a produzir um relatório intitulado "Dieta, Nutrição e Câncer" (National Research Council, Committee on Diet, Nutrition, and Cancer, Commission on Life Sciences, \& Division on Earth and Life Studies, 1982). À época, o Comitê de Nutrição e Dietética [Food and Nutrition Board] da Academia Nacional de Ciências [National Academy of Science], ampla e abertamente financiado pela indústria pecuária, veiculava campanhas de incentivo ao consumo de carne, moldando e incutindo a prática do consumo de produtos derivados de animais à cultura estadunidense (Campbell \& Campbell, 2006). Levando em conta que os EUA são o principal foco atual de referência cultural do ocidente, além de terem sido a maior potência econômica do mundo em boa parte do século XX, essa prática alimentar recebeu justificada difusão mundial e repercute aos dias de hoje.

Já em 2015, o supracitado comitê - atualmente renomeado Comitê Consultivo para Orientações Alimentares [The Dietary Guidelines Advisory Committee] - ressoando as últimas recomendações da ONU (Carus, 2015), recomendou a dieta vegana afirmando que a alimentação sem produtos de origem animal é mais eficaz para a saúde e também para combater o aquecimento global. Alguns meses antes, em novembro de 2014, o governo brasileiro através do Ministério da Saúde admitiu que produtos de origem animal podem ser prejudiciais à saúde e certamente são prejudiciais ao meio ambiente (Ministério da Saúde. Secretaria de Atenção à Saúde. Departamento de Atenção Básica., 2014):

A diminuição da demanda por alimentos de origem animal reduz notavelmente as emissões de gases de efeito estufa (responsáveis pelo aquecimento do 
planeta), o desmatamento decorrente da criação de novas áreas de pastagens e o uso intenso de água. O menor consumo de alimentos de origem animal diminui ainda a necessidade de sistemas intensivos de produção animal, que são particularmente nocivos ao meio ambiente. Típica desses sistemas é a aglomeração de animais, que, além de estressá-los, aumenta a produção de dejetos por área e a necessidade do uso contínuo de antibióticos, resultando em poluição do solo e aumento do risco de contaminação de águas subterrâneas e dos rios, lagos e açudes da região. Sistemas intensivos de produção animal consomem grandes quantidades de rações fabricadas com ingredientes fornecidos por monoculturas de soja e de milho. Essas monoculturas, por sua vez, dependem de agrotóxicos e do uso intenso de fertilizantes químicos, condições que acarretam riscos ao meio ambiente, seja por contaminação das fontes de água, seja pela degradação da qualidade do solo e aumento da resistência de pragas, seja ainda pelo comprometimento da biodiversidade. $\mathrm{O}$ uso intenso de água e o emprego de sementes geneticamente modificadas (transgênicas), comuns às monoculturas de soja e de milho, mas não restritos a elas, são igualmente motivo de preocupações ambientais (p.31-32).

Concluindo, o consumo de carne, reforçado historicamente como objeto de expressão de poder e influência social, continua exercendo o papel de indicador de poder aquisitivo em diversas culturas, a brasileira inclusa (Martins, Igreja, Bini, Perez, \& Rocha, 2011). Apesar disso, é identificável no contexto atual da humanidade uma tendência à mudança de paradigmas. Embasados por teorias e conceitos que remontam até mesmo à pré-história, o veganismo vem se afirmando como movimento social ao concentrar suas ações no ativismo em prol da mudança de comportamento em conformidade com a demanda preservacional da vida do planeta. Curiosamente, há um 
aparente paradoxo na conceituação do movimento vegano como um movimento social.

\section{Movimento social ou estilo de vida?}

Os dias atuais presenciam grande segmentação de grupos de minoria, centrados em características identitárias que permitem aos indivíduos buscar, mais diretamente, soluções para as questões concernentes a sua vivência pessoal. Exemplos disso podem ser observados na segmentação articulada de movimentos sociais já consolidados em subclasses que carregam consigo características mais detalhadas do pertencimento, como na segmentação do feminismo em feminismos negro, popular, radical, liberal, entre diversos outros (Costa, 2005; Dunn \& Rowbotham, 1989). Cada subdivisão surge de um momento histórico, uma demanda, um contexto social e atende às particularidades da coletividade que a reivindicou, sem divergir significativamente o suficiente para que se caracterize como um movimento social isolado. Diversas outras dissidências de movimentos sociais e ideologias se formaram e prosperaram ou sucumbiram ao longo do tempo. O movimento vegano se enquadra nesse cenário por sua raiz comum com o movimento ecoativista de preservação ambiental.

O enquadramento de um grupo como movimento social pode ser avaliado de diversas maneiras. De acordo com a teoria dos novos movimentos sociais de Gohn (2003), a característica fundamental é que o grupo seja focado em ações sociais coletivas (denúncia, mobilizações, marchas, concentrações, passeatas, ameaças à ordem constituída, desobediência civil, etc.) de caráter sociopolítico e cultural que viabilizam distintas formas de organização e expressão das demandas da população. Podem, ainda, ser de dois tipos: conservadores ou progressistas. No primeiro, caracterizam-se por serem essencialmente xenofóbicos, nacionalistas, radicais religiosos, ou racistas. Não buscam mudanças emancipatórias, mas sim mudanças que atendem seus interesses particulares, pela força, usando a violência como estratégia. São movimentos 
intolerantes e sectários que negam a ordem social vigente. No segundo caso, por sua vez, possuem agenda emancipatória, pois "realizam diagnósticos sobre a realidade social e constroem propostas. Atuam em redes, articulando ações coletivas que agem como resistência à exclusão e lutam pela inclusão social." (p.14-15). O fenômeno do associativismo - tendência ou movimento dos indivíduos de se congregarem em associações representativas, para a defesa de seus interesses - permite a formação dessas redes, que viabilizam a exposição dos princípios, conceitos e ideias dos grupos nas comunidades, nos novos meios de comunicação - como as redes sociais (internet) e em círculos sociais de redes temáticas (p. ex.: grupos de mulheres sobre feminismo), redes socioculturais (p. ex.: grupos étnicos, religiosos), entre outros exemplos. Dentro dessas redes, há trocas de ideias que fortalecem e reafirmam o pertencimento aos grupos. Essas trocas têm, portanto, a função de empoderamento dos indivíduos que dela participam. O empoderamento proveniente dessas interações trazem a ânsia por conformidade normativa (ou consenso ideológico) com todo o corpo social. A tentativa de influência social realizada no sentido de modificar atitudes, comportamentos e ideias de quem não pertence ao grupo, nem participa das redes de seus atores, é uma forma de ativismo.

O conceito de ativismo varia entre as ciências, a mídia e o senso comum. $\mathrm{Na}$ filosofia, caracteriza-se pela "vontade criativa que prega a prática efetiva para transformar a realidade em lugar da atividade puramente especulativa" (Weiszflog, 2008); a mídia considerada mainstream tende a figurar o protesto e o ativismo como formas de terrorismo, influenciando negativamente a população a construir um distanciamento desse tipo de prática; nas ciências sociais e políticas, por sua vez, o ativismo possui um caráter interventivo enfático que beira a violência:

Doutrina ou prática de dar ênfase à ação vigorosa, por exemplo, ao uso da força 
para fins políticos; militância política; ação intencional que decorre de uma grande variedade de motivações políticas e pode assumir diversas modalidades de expressão, como, por exemplo, o envio de cartas à mídia impressa e eletrônica, comícios, greves, sabotagem, resistência passiva ao governo, manifestações de rua e, nos casos mais extremos, táticas de guerrilha e terrorismo (Weiszflog, 2008) Conforme exposto anteriormente, o ativismo de movimentos sociais é atualmente considerado uma prática de grupos empoderados por suas redes, muitas vezes focados exclusivamente nas ações coletivas, públicas e episódicas, que obedecem a uma organização centralizada e contestam instituições formais, em oposição aos movimentos de estilo de vida - individualizados, privados, contínuos e orientados contra normas e práticas culturais (Haenfler, Johnson, \& Jones, 2012). Porém, algumas divergências em relação a essa conceituação têm surgido nas últimas décadas. Estudos recentes ressaltam que o comportamento cotidiano é tão importante para a compreensão das práticas políticas e do ativismo quanto as ações em grupo, colocando o dia-a-dia como central para a produção de espaços de ação social ativista. Diversos autores demonstraram a importância dos espaços privativos na formação do posicionamento político, evidenciando a necessidade de se produzir a ciência do ativismo social a partir de uma perspectiva menos centrada nas ações interventivas e públicas, dando ênfase à forma como se constrói socialmente o indivíduo ativista (Maxey, 1999; Melucci, 1985; Scott, 2000; Véron, 2016). Assim, identifica-se uma tendência à abolição da figura do “militante dedicado à mudança revolucionária e distante da mundanidade da vida cotidiana" (Chatterton \& Pickerill, 2010).

À luz do exposto, o veganismo poderia ser visto como um movimento social progressista. Mas como poderia ser, se advoga por uma causa que não propõe a inclusão social de seus próprios membros diretamente? Ao contrário, propõe mudanças que, por 
meio de adequações comportamentais, econômicas e políticas, protegeriam os animais da exploração, em detrimento da manutenção do estilo de vida do ser humano contemporâneo. Talvez o problema nesta definição de movimentos sociais seja o excessivo antropocentrismo em sua fundamentação. Além disso, o foco em ações coletivas dado pela teoria dos novos movimentos sociais dificulta o enquadramento do veganismo, pois esse comportamento não é tão comum a esse grupo quanto para outros.

Apesar disso, o veganismo, na consequente intersecção entre o movimento social pelos direitos animais e o estilo de vida vegetariano, configura-se como um movimento, em emergência em diversas sociedades ocidentais da atualidade, que se empodera em suas redes, articulando algumas ações coletivas (congressos, ações interventivas, boicotes, ou denúncias) que agem como uma forma de resistência e traz em sua base a ideia de que nem todo movimento social age exclusivamente em função da sociedade humana. O presente trabalho, portanto, interpretará o ativismo vegano como um conjunto de práticas comportamentais fundamentadas na comunalidade entre as formas supracitadas - movimento social e estilo de vida - de interpretação de movimentos sociais.

\section{Ativismo vegano}

Conforme dito anteriormente, o movimento vegano compartilha semelhanças com o movimento social ecoativista - este, último, que se enquadra nos critérios básicos para sua caracterização como novo movimento social progressista. Ao se posicionar contra as investidas do mercado capitalista, os interesses da indústria agropecuária e o senso comum do consumo alimentar das sociedades ocidentais, o movimento vegano começou a se afirmar como minoria social ativa. Por ser, de certa forma, recente, a diferenciação em relação aos movimentos focados na preservação ambiental ainda é tida como tênue. Então, o que os faz distintos? 
Tomemos por exemplo os movimentos ecoativistas de preservação ambiental, tais como o Greenpeace, ou a WWF (World Wildlife Fund). A primeira apresenta como missões, em seu site oficial, motivos como: "Defender os oceanos com a criação de uma rede de unidades de conservação e o estímulo da pesca sustentável”' (Greenpeace, 2010); a segunda "trabalha para reduzir o impacto da ação do homem na natureza com objetivo de harmonizar a atividade humana e a conservação da biodiversidade, promovendo o uso racional dos recursos naturais em benefício dos cidadãos de hoje e das futuras gerações" (WWF Brasil, n.d.). Em contrapartida, organizações veganas como a ALF (Animal Liberation Front) e o PETA (People for the Ethical Treatment of Animals) trazem em suas missões: “focar a atenção no combate às áreas onde animais sofrem mais intensamente: indústria alimentícia, de vestuário, de entretenimento, de extermínio de animais considerados pestes, e contra a crueldade contra animais domésticos e de laboratório" (PETA, n.d.) e "efetivamente alocar recursos (tempo e dinheiro) para dar fim ao status de 'propriedade' dos animais não humanos” (Animal Liberation Front, n.d.). Ainda que ambos apregoem críticas ao antropocentrismo e o fim da dominação humana que leva à exploração e devastação, há diferenças fundamentais quanto à forma como se pretende alcançar esse objetivo (Kirjner \& Kemmerer, 2015). O ativismo vegano critica e propõe discussões em quatro principais linhas de argumentação, conforme exposto por Santana, Santana, e Trajano (2015):

Argumento ecológico: com base, por exemplo, em discussões sobre o desmatamento para a produção de ração para a pecuária, produção esta que corresponde a mais de $70 \%$ de todas as terras destinadas ao plantio no mundo. Além disso, por exemplo, há o argumento do desperdício, uma vez que cada quilo de carne bovina consome cerca de 15 mil litros de água (Chapagain \& Hoekstra, 2008) e a questão do efeito estufa, causado pela emissão de gases pelo gado. Nesta categoria de 
argumentação, portanto, reside a crítica aos argumentos preservacionistas de sustentabilidade ambiental;

Argumento econômico: parte do fato de que um terço dos grãos produzidos no mundo são destinados à alimentação do gado, justificando em muitos casos a fome em países produtores de grãos exclusivamente para exportação, em detrimento de sua população, condenada a consumir produtos caríssimos advindos da importação. Além disso, há também o desperdício, visto que no espaço e tempo onde se produz 210 quilos de carne - ou apenas um boi -, é possível colher 34 toneladas de milho, 19 toneladas de arroz ou 32 toneladas de soja. Aqui, cabe também críticas ao sistema capitalista, que permite a objetificação dos animais em produtos, geradores de lucro e, portanto, alvo de exploração;

Argumento de saúde pública: disserta sobre a obesidade gerada pela adoção de dietas baseadas em farinha branca, açúcares refinados e carne - que tem sua produção e venda barateados por políticas de produção voltadas ao mercado da pecuária. Aqui se enquadra o grande motivo de adesão ao veganismo por boa parte de seus praticantes. Estudos apontam que quando o veganismo é adotado por razões de saúde, a permanência na prática é menos duradoura (Radnitz et al., 2015);

Argumento político: que trata da relevância da dieta vegetariana na legitimação da luta pelos direitos animais. Neste quesito reside outro grande motivo para a prática do veganismo, que é o combate à exploração e crueldade animal. É, portanto, nesta categoria que se encaixam as posturas de buycott e questionamento social característicos do veganismo.

Ativistas pelos direitos animais buscam, portanto, a mudança de comportamento a partir da quebra de paradigma socioeconômico a favor do fim da exploração animal, promovendo um estado de equilíbrio interespecífico igualitário, 
fundamentado no antiespecismo. Ao contrário, o ecoativismo busca a manutenção sustentável e responsável dos ecossistemas, respeitando a expansão humana, advogando a favor do progresso e adaptação dos biomas às necessidades sociais, ao mesmo tempo em que propõe recuperar organizadamente o que já foi devastado (Kirjner \& Kemmerer, 2015). Ou seja, a fronteira que divide esses dois movimentos é óbvia à medida em que se reconhece a fragilidade do termo "sustentável”, pois a crítica vegana em sua inserção no movimento pelos direitos animais é, exatamente a de que a expansão humana é incompatível com a preservação ambiental e, portanto, insustentável.

Concluindo, as raízes comuns com movimentos sociais ambientalistas, o estilo de vida vegetariano e posturas político-econômicas anti-capitalismo podem fazer com que as representações sociais dos não veganos sobre o movimento vegano sejam enviesadas, tornando sua construção distante do que é, de fato, a realidade desse grupo para seus integrantes. A recente popularização da ideologia pode estar influenciando e transformando a representação social dos veganos no Brasil e, portanto, o presente estudo pretende gerar conhecimento teórico e prático sobre movimentos sociais de minorias ativas por meio de suas representações sociais.

\section{Perguntas de pesquisa}

\section{Parte 1 - Veganos}

a. Por se tratar de um grupo organizado ao redor da proposta da libertação animal, é esperado que o movimento vegano possua autorrepresentações sociais;

b. Estas representações os enquadrariam como um movimento social formado por uma minoria ativa, de acordo com suas respectivas teorias;

c. Este grupo possui uma identidade, construída em relação/oposição aos 
não veganos.

Parte 2 - Não veganos

a. Os não veganos também possuem representações sociais construídas sobre o veganismo;

b. Estas representações coincidem com o conceito de veganismo que os veganos defendem;

c. As representações possuem conteúdo estereotipado e pejorativo sobre veganos.

\section{Objetivos}

\section{Objetivo geral}

Acessar, descrever e analisar as representações sociais construídas por veganos e não veganos sobre o veganismo.

\section{Objetivos específicos}

a. Avaliar os elementos das representações sociais construídas por veganos que permitem a classificação desse grupo como movimento social de minoria ativa;

b. Comparar as representações manifestadas pelos dois grupos e verificar a presença de contrastes, de forma a permitir a discussão sobre os meios usados pelos veganos para influenciar a maioria não vegana. 


\section{ESTUDO 1}

Submetido à revista Psicologia USP 
"Amar independe de espécie": Autorrepresentações do movimento social vegano brasileiro

"Love sees no species": The self-representations of the Brazilian vegan social movement

"El amor es independiente de las especies": auto-representaciones del movimiento social vegano brasileño

« L'amour est indépendante des espèces »: Les auto-représentations du mouvement social végétalien brésilien

Luiz Otávio Esteves, Ana Lúcia Galinkin

Correspondências referentes a este artigo devem ser enviadas para Luiz Otávio Bastos Esteves, à Secretaria do Programa de Pós-graduação em Psicologia Social, do Trabalho e das Organizações, Instituto de Psicologia, Instituto Central de Ciências da Universidade de Brasília - UnB, Campus Darcy Ribeiro, Asa Norte, Brasília - DF, CEP 70904-970. E-mail: luizobe@gmail.com

\section{Resumo}

O movimento social vegano brasileiro está entre os maiores do mundo, com cerca de 5 milhões de adeptos. Recentemente começaram a surgir os primeiros estudos sobre o aspecto sociopolítico do comportamento desse grupo. O presente estudo buscou acessar, descrever e analisar as representações sociais construídas por veganos sobre o próprio veganismo a partir da teoria do núcleo central das representações sociais de Abric (1976), pelo uso de questionários de evocação de palavras e análise lexical das justificativas das evocações. Os resultados sugerem que elementos de autotranscendência humana guiam o comportamento dos indivíduos deste grupo na busca por um mundo de igualdade entre todas as espécies. Além disso, o aspecto ativista sociopolítico do veganismo encontra-se nas 
periferias da representação, sugerindo que este é um aspecto que só recentemente vem se tornando parte fundamental do que é ser vegano para essa população.

Palavras-chave: Representações sociais; veganismo; movimentos sociais; estilo de vida.

\begin{abstract}
The Brazilian vegan social movement is among the largest around the world, with around 5 million adepts. Recently the first studies about the sociopolitical aspects of the behavior of this group came to light. Using word evocation and lexical analysis of the justifications of evocations as per the central nucleus approach, this study sought to access, describe and analyze the social representations built by vegans about veganism itself. Results suggest that human self-transcendence elements guide the behavior of this group in pursuit of a world of equality between all species. In addition, the aspect of sociopolitical activism of veganism is found only on the second periphery of the social representation, suggesting that this is an aspect that only recently became cardinal of what means being vegan for this population.
\end{abstract}

Keywords: Social representations; veganism; social movements; lifestyle.

\title{
Resumen
}

El movimiento social vegano brasileño está entre los más grandes del mundo, con aproximadamente 5 millones de partidarios. Recientemente han comenzado a aparecer los primeros estudios sobre el aspecto socio-político del comportamiento de este grupo. Este estudio buscó el acceso, la descripción y el análisis de las representaciones sociales construidas por los propios veganos acerca del veganismo a partir de la teoría del núcleo central de las representaciones sociales de Abric (1976), mediante el uso de cuestionarios de evocación de palabras 
y análisis del léxico de las justificaciones de las evocaciones . Los resultados sugieren que los elementos de trascendencia humana guían el comportamiento de los individuos de este grupo en la búsqueda de un mundo de igualdad entre todas las especies. Además, el aspecto activista sociopolítico del veganismo está en las afueras de la representación, sugieriendo que esto es algo que sólo recientemente se ha convertido en una parte fundamental de lo que es ser vegano para esta población.

Palabras llave: Representaciones sociales; veganismo; movimiento; estilo de vida.

\section{Résumé}

Le mouvement végan brésilien est parmi les plus grands au monde avec environ cinq millions d'adeptes. Les premières études à propos de l'aspect socio-politique du comportement de ce groupe sont apparues récemment. L'étude suivante a eu pour but d'accéder, de décrire et d'analyser les représentations sociales construites par les vegans sur le propre véganisme en partant de la théorie du noyau central des représentations sociales de Abric (1976) et en utilisant pour cela des questionnaires d'évocation de mots ainsi que l'analyse léxicale des justifications d'évocations. Les résultats suggèrent que des éléments de l'auto-transcendance humaine guident le comportement des individus de ce groupe dans la recherche d'un monde d'égalité entre toutes les espèces. De plus, l'aspect militant sociopolitique du véganisme se trouve de façon marginale à la représentation, ce qui suggère que le militantisme vegan est un aspect qui n'est que récemment devenu un élément fondamental de ce qu'être végan pour cette population.

Mots-clés: Représentations sociales; Le véganisme; Mouvement social; mode de vie. 


\section{Introdução}

O movimento social vegano vem ganhando espaço na sociedade brasileira, posto que, dos atuais 200 milhões de habitantes do Brasil, cerca de $8 \%$ são vegetarianos (IBOPE, 2012) e, desses, aproximadamente 28,6\% são veganos (Chaves, 2012), correspondendo a aproximadamente 5 milhões de indivíduos. Em termos numéricos absolutos, o Brasil seria o primeiro colocado mundial em número de veganos, de acordo com a escassa literatura sobre o assunto. Já em termos estatísticos, com aproximadamente $2,5 \%$ de sua população vegana, o Brasil ocupa a sexta colocação mundial (Tabela 1). Essa colocação é incerta, uma vez que a prática deste censo só foi realizada em alguns poucos países.

$\mathrm{Na}$ academia latino-americana, o interesse também é recente. Até o final da primeira década do século XXI, artigos, publicações e teses se focavam majoritariamente na característica dietética da ideologia vegana, como em Harris (1999), que ao tratar das características culturais das sociedades do mundo, cita o veganismo como uma prática alimentar associada a diversas religiões, como o budismo e o hinduísmo. À época, poucos são os trabalhos de pesquisa que se dirigiram ao aspecto ético do comportamento vegano. Entre as poucas exceções, Román \& Vilaplana (2002) publicaram um livro dedicado a discutir o aspecto ético do veganismo na alimentação livre de produtos animais. Fugindo do foco dietético, Brügger (2009) discute os estudos animais, o veganismo e o abolicionismo como caminho para uma postura não antropocêntrica de preservação ambiental e sustentabilidade. No final da década, pesquisadores começavam, portanto, a esboçar a mudança de paradigma que se seguiria nas discussões sobre o tema, como visto em Gomes, Silva, \& Carmo (2010) que discutiam a influência da propaganda que denuncia as práticas cruéis contra animais no crescimento de adeptos do 
vegetarianismo estrito.

A importância do aspecto ativista social e político do veganismo brasileiro começava a vir à tona (Nunes, 2010; Trigueiro, 2013), abrindo as portas da academia para estudos como o de Ferrigno (2012), que realizou um estudo etnográfico do veganismo como movimento político, caracterizando a formação do grupo e suas dinâmicas sociais, principais motivações, discussões e mobilizações do ativismo abolicionista vegano. Aspectos como o boicote ao mercado que explora animais para os mais diversos fins vieram à luz da academia brasileira também nessa época, revelando a faceta ética do comportamento vegano para além da alimentação (Nascimento \& Silva, 2012). Começava ali, portanto, uma era de estudos sobre o veganismo como prática cultural (Lopes \& Arruda, 2014), movimento social político (Souza, 2016) e também como minoria discriminada e marginalizada socialmente (Pazzini, 2014).

Por ser recente, o reconhecimento do veganismo como um movimento social minoritário, organizado ao redor de sua ideologia ainda é fraco. Isso reforça a necessidade de estudos como o presente, onde pretendeu-se acessar, descrever e analisar as representações sociais construídas por veganos sobre o próprio veganismo. Dessa forma, será possível a discussão sobre sua inserção social, a forma como se estrutura seu ativismo e como é percebida a sua experiência social não hegemônica.

\section{Representações sociais}

O fundamento teórico desta investigação é a teoria das representações sociais. Partindo, em meados da década de 1960, do conceito de representações coletivas (Durkheim, 1898), onde o saber coletivo e as formas de consciência eram impostos culturalmente pela sociedade aos seus indivíduos, Serge Moscovici propõe essa teoria, 
que torna possível que pesquisadores acessem os construtos representativos criados sobre os mais diversos temas. A diferença fundamental entre esta abordagem e a utilizada por Durkheim é que o saber coletivo para Moscovici é gerado, transformado e compartilhado pelos sujeitos sociais, ao invés da subjugação do indivíduo a uma ideia social imposta a ele, da qual não é propriamente ativo em sua construção.

Originada em seu trabalho seminal La psychanalyse, son image et son public (Moscovici, 1961), a TRS parte de uma perspectiva que busca compreender o ser humano, considerando-o como sujeito construído a partir de suas determinações evolutivas, históricas, culturais e sociais e que também é agente de sua própria realidade social. As representações sociais caracterizam-se como um espaço de trocas que se retroalimenta, viabilizando, produzindo e transformando as próprias trocas. São definidas como um saber acerca do real que se estrutura na relação do sujeito com o objeto, mediada pelas interações com o outro. Ou seja, são construções e rearranjos cognitivos que permitem ao indivíduo explicar e compreender a realidade, justificando sua participação ou ausência em determinado contexto ou grupo. Dessa forma, representam um conjunto de saberes práticos criados a partir da interação com o outro (no sentido lato) que guiam a interpretação da realidade. Toda representação social é construída de forma que evite o conflito cognitivo. Portanto, a partir do contato com o outro, cada indivíduo absorve e transforma o conhecimento adquirido de forma a justificar e manter sua identidade individual ou grupal.

Para Moscovici, a assimilação desse conhecimento é sujeita a dois processos: objetivação e ancoragem. No primeiro, o conhecimento é transformado em imagens concretas por aproximação e reagrupamento de ideias e imagens que se enquadram no mesmo tema. Já no segundo, a imagem criada no primeiro processo é relacionada e comparada a conhecimentos prévios para que surja um conceito 
sobre o conhecimento que obedeça às necessidades do indivíduo para reforçar sua identidade individual ou grupal. Portanto, objetivação e ancoragem servem a função de tornar familiar o desconhecido e solucionar o conflito cognitivo do contato com o novo.

Dos desdobramentos realizados no decorrer dos anos, muito bem sintetizados em Sá (1998), o presente estudo faz uso da teoria do núcleo central (TNC), proposta por Abric (1976) para acessar, investigar a analisar as representações sociais deste grupo. A TNC propõe que as representações sociais possuem uma organização estrutural construída ao redor de um núcleo composto por elementos cognitivos mais estáveis, rígidos e consensuais e apresenta elementos individualizados, mutáveis e flexíveis em sua periferia. A teoria do núcleo central, portanto, postula que as representações se organizam ao redor de um núcleo central normativo, bastante rígido e perene representativo das condições históricas do grupo, construído em função do sistema de normas em que se está inserido - e de sistemas periféricos funcionais, resultantes da experiência individual e que permitem que as representações sejam flexíveis e adaptáveis. É nos sistemas periféricos que se encontram os elementos de manutenção do núcleo central, ou seja, qualquer novo elemento que possa interferir na representação é avaliado e adaptado a partir dos sistemas periféricos, de forma a evitar que o núcleo central seja colocado em xeque.

A abordagem Estrutural (Abric, 1976), busca identificar a estrutura das representações sociais a partir da análise da evocação de palavras e de sua categorização. Esta análise viabiliza o reconhecimento dos elementos formadores, centrais e periféricos, das representações sociais. Com isso, é possível verificar a existência de um processo de transformação das representações sociais (FonteneleMourão, 2006). Considerando que este é um movimento de emergência recente no 
Brasil, os sistemas periféricos das representações dos veganos devem revelar quais os temas e valores que são utilizados pelos veganos para defender sua ideologia, quais estão sendo negociados entre seus praticantes e quais são centrais e primordiais para sua fundamentação.

Concluindo, a partir do pressuposto de que as representações sociais são construídas obedecendo a demanda de não criar dissonâncias cognitivas e, portanto, reforçam a identidade de quem as compartilha, o presente estudo buscou acessar, descrever e analisar as representações sociais de veganos sobre o veganismo. Esperouse encontrar valores e crenças reforçadores da própria ideologia vegana no núcleo central. Este núcleo estaria cercado por outros valores e crenças que refletem a forma como se dão as relações sociais destes indivíduos.

\section{Veganismo}

Vegan, termo originado em 1944 por um dos fundadores da British Vegan Society e que, segundo seu próprio autor, significa "o alfa e o ômega dos vegetarianos" (veg/etari/an) (Watson, 1965), denotando que devia ser a causa e a finalidade da opção pela abstenção do consumo de animais na dieta - muitas vezes motivada por determinação religiosa, por objetivos nutricionais e de saúde, ou por consciência ecológica. A ideologia vegana vai bastante além da adaptação dietária, uma vez que se fundamenta no vegetarianismo estrito (onde não há consumo de nenhum tipo de carne, laticínio, ovos, mel, corantes produzidos a partir animais, gelatina, entre outros ingredientes de origem animal) e se combina ao buycott (Friedman, 1996) por abstenção do consumo dos produtos e serviços oferecidos pelo mercado que pratica exploração animal (cosméticos e medicamentos testados em animais, vestuário de couro, lã, seda e peles, transportes movidos por tração animal, entre outros). Ou seja, ao mesmo tempo em que é um tipo de dieta, o 
veganismo é uma filosofia de vida, uma postura ética e política e, por sua característica vinculativa ao abolicionismo animal, um ato de desobediência civil (Argolo, 2008).

História, embasamentos, conflitos, contrastes e intersecções.

Para compreender os princípios fundamentais dessa ideologia, é possível traçar uma linha de raciocínio que remonta à pré-história: desde estudos de historiadores refutando a origem caçadora do homem primitivo (Hart \& Sussman, 2005; Phelps, 2007; Spencer, 1996), representações da alimentação nas idades antiga e média (Flandrin et al., 1998), tratados filosóficos pró-vegetarianismo (Boyd, 1936; Oliveira, 2013), o uso do alimento como reafirmador de hierarquias sociais desde a era feudal à atualidade (Adamson, 2004; Carlin \& Rosenthal, 1998; Tobin, 1999), políticas públicas que favoreciam a prática da indústria pecuária no século XX (Campbell \& Campbell, 2006), até as recentes recomendações da ONU para que a população mundial adira à dietas livres de produtos animais para preservar o meio ambiente (Carus, 2015). De forma geral, o consumo de carne, reforçado historicamente como objeto de expressão de poder e influência social, continua exercendo o papel de indicador de poder aquisitivo e hierarquia social em diversas culturas, a brasileira inclusa (Martins et al., 2011; Torres \& Allen, 2006). Apesar disso, é identificável no contexto atual da humanidade uma tendência à mudança de paradigmas. Embasados por teorias e conceitos que remontam até mesmo à pré-história, o veganismo vem se afirmando como movimento social ao concentrar suas ações no ativismo em prol da mudança de comportamento em conformidade com a demanda preservacional da vida do planeta.

\section{Veganismo - Movimento social ou estilo de vida?}

Os dias atuais presenciam grande segmentação de grupos de minoria, centrados em características identitárias que permitem aos indivíduos buscar, mais diretamente, 
soluções para as questões concernentes a sua vivência pessoal. Exemplos disso podem ser observados na segmentação articulada de movimentos sociais já consolidados em subclasses que carregam consigo características mais detalhadas do pertencimento, como na segmentação do feminismo em feminismos negro, popular, radical, liberal, entre diversos outros (Costa, 2005; Dunn \& Rowbotham, 1989). Cada subdivisão surge de um momento histórico, uma demanda, um contexto social e atende às particularidades da coletividade que a reivindicou, sem divergir significativamente o suficiente para que se caracterize como um movimento social isolado. Diversas outras dissidências de movimentos sociais e ideologias se formaram e prosperaram ou sucumbiram ao longo do tempo. O movimento vegano se enquadra nesse cenário por sua raiz comum com os movimentos ecoativistas de preservação ambiental.

O enquadramento de um grupo como movimento social pode ser avaliado de diversas maneiras. De acordo com a teoria dos novos movimentos sociais de Gohn (2003), a característica fundamental é que o grupo seja focado em ações sociais coletivas (denúncia, mobilizações, marchas, concentrações, passeatas, ameaças à ordem constituída, desobediência civil, etc.) de caráter sociopolítico e cultural que viabilizam distintas formas de organização e expressão das demandas da população. Podem, ainda, ser de dois tipos: conservadores ou progressistas. No primeiro, caracterizam-se por serem essencialmente xenofóbicos, nacionalistas, radicais religiosos, ou racistas. Não buscam mudanças emancipatórias, mas sim mudanças que atendem seus interesses particulares, pela força, usando a violência como estratégia. São movimentos intolerantes e sectários que negam a ordem social vigente. No segundo caso, por sua vez, possuem agenda emancipatória, pois "realizam diagnósticos sobre a realidade social e constroem propostas. Atuam em redes, articulando ações coletivas que agem como resistência à exclusão e lutam pela inclusão social." (p.14-15). O fenômeno do 
associativismo - tendência ou movimento dos indivíduos de se congregarem em associações representativas, para a defesa de seus interesses - permite a formação dessas redes, que viabilizam a exposição dos princípios, conceitos e ideias dos grupos nas comunidades, nos novos meios de comunicação - como as redes sociais (internet) e em círculos sociais de redes temáticas (p. ex.: grupos de mulheres sobre feminismo), redes socioculturais (p. ex.: grupos étnicos, religiosos), entre outros exemplos. Dentro dessas redes, há trocas de ideias que fortalecem e reafirmam o pertencimento aos grupos. Essas trocas têm, portanto, a função de empoderamento dos indivíduos que dela participam. O empoderamento proveniente dessas interações trazem a ânsia por conformidade normativa (ou consenso ideológico) com todo o corpo social. A tentativa de influência social realizada no sentido de modificar atitudes, comportamentos e ideias de quem não pertence ao grupo, nem participa das redes de seus atores, é uma forma de ativismo.

O conceito de ativismo varia entre as ciências, a mídia e o senso comum. $\mathrm{Na}$ filosofia, caracteriza-se pela "vontade criativa que prega a prática efetiva para transformar a realidade em lugar da atividade puramente especulativa (Companhia Melhoramentos de São Paulo, 2015); a mídia considerada mainstream tende a figurar o protesto e o ativismo como formas de terrorismo, influenciando negativamente a população a construir um distanciamento desse tipo de prática; nas ciências sociais e políticas, por sua vez, o ativismo possui um caráter interventivo enfático que beira a violência:

Doutrina ou prática de dar ênfase à ação vigorosa, por exemplo, ao uso da força para fins políticos; militância política; ação intencional que decorre de uma grande variedade de motivações políticas e pode assumir diversas modalidades de expressão, como, por exemplo, o envio de cartas à mídia impressa e eletrônica, 
comícios, greves, sabotagem, resistência passiva ao governo, manifestações de rua e, nos casos mais extremos, táticas de guerrilha e terrorismo (Companhia Melhoramentos de São Paulo, 2015)

Conforme exposto anteriormente, o ativismo de movimentos sociais é atualmente considerado uma prática de grupos empoderados por suas redes, muitas vezes focados exclusivamente nas ações coletivas, públicas e episódicas, que obedecem a uma organização centralizada e contestam instituições formais, em oposição aos movimentos de estilo de vida - individualizados, privados, contínuos e orientados contra normas e práticas culturais (Haenfler et al., 2012). Porém, algumas divergências em relação a essa conceituação têm surgido nas últimas décadas. Estudos recentes ressaltam que o comportamento cotidiano é tão importante para a compreensão das práticas políticas e do ativismo quanto as ações em grupo, colocando o dia-a-dia como central para a produção de espaços de ação social ativista. Diversos autores demonstraram a importância dos espaços privativos na formação do posicionamento político, evidenciando a necessidade de se produzir a ciência do ativismo social a partir de uma perspectiva menos centrada nas ações interventivas e públicas, dando ênfase à forma como se constrói socialmente o indivíduo ativista (Maxey, 1999; Melucci, 1985; Scott, 2000; Véron, 2016). Assim, identifica-se uma tendência à abolição da figura do “militante dedicado à mudança revolucionária e distante da mundanidade da vida cotidiana" (Chatterton \& Pickerill, 2010).

À luz do exposto, o veganismo poderia ser visto como um movimento social progressista. Mas como poderia ser, se advoga por uma causa que não propõe a inclusão social de seus próprios membros diretamente? Ao contrário, propõe mudanças que, por meio de adequações comportamentais, econômicas e políticas, protegeriam os animais da exploração, em detrimento da manutenção do estilo de vida do ser humano 
contemporâneo. Talvez o problema nesta definição de movimentos sociais seja o excessivo antropocentrismo em sua fundamentação. Além disso, o foco em ações coletivas dado pela teoria dos novos movimentos sociais dificulta o enquadramento do veganismo, pois esse comportamento não é tão comum a esse grupo quanto para outros.

Apesar disso, o veganismo, na consequente intersecção entre o movimento social pelos direitos animais e o estilo de vida vegetariano, configura-se como um movimento, em emergência em diversas sociedades ocidentais da atualidade, que se empodera em suas redes, articulando algumas ações coletivas (congressos, ações interventivas, boicotes, ou denúncias) que agem como uma forma de resistência e traz em sua base a ideia de que nem todo movimento social age exclusivamente em função da sociedade humana. O presente trabalho, portanto, interpretará o ativismo vegano como um conjunto de práticas comportamentais fundamentadas na comunalidade entre as formas supracitadas - movimento social e estilo de vida - de interpretação de movimentos sociais.

\section{Ativismo vegano}

Conforme dito anteriormente, o movimento vegano compartilha semelhanças com os movimentos sociais ecoativistas - este último, que se enquadra nos critérios básicos para sua caracterização como novo movimento social progressista. Ao se posicionar contra as investidas do mercado capitalista, os interesses da indústria agropecuária e o senso comum do consumo alimentar das sociedades ocidentais, o movimento vegano começou a se afirmar como minoria social ativa. Por ser, de certa forma, recente, a diferenciação em relação aos movimentos focados na preservação ambiental ainda é tida como tênue. Então, o que os faz distintos?

Tomemos por exemplo os movimentos ecoativistas de preservação ambiental, tais como o Greenpeace, ou a WWF (World Wildlife Fund). A primeira apresenta como 
missões, em seu site oficial, motivos como: "Defender os oceanos com a criação de uma rede de unidades de conservação e o estímulo da pesca sustentável" (Greenpeace, 2010); a segunda "trabalha para reduzir o impacto da ação do homem na natureza com objetivo de harmonizar a atividade humana e a conservação da biodiversidade, promovendo o uso racional dos recursos naturais em benefício dos cidadãos de hoje e das futuras gerações” (WWF Brasil, n.d.). Em contrapartida, organizações veganas como a ALF (Animal Liberation Front) e o PETA (People for the Ethical Treatment of Animals) trazem em suas missões: "focar a atenção no combate às áreas onde animais sofrem mais intensamente: indústria alimentícia, de vestuário, de entretenimento, de extermínio de animais considerados pestes, e contra a crueldade contra animais domésticos e de laboratório" (PETA, n.d.) e "efetivamente alocar recursos (tempo e dinheiro) para dar fim ao status de 'propriedade' dos animais não humanos” (Animal Liberation Front, n.d.). Ainda que ambos apregoem críticas ao antropocentrismo e o fim da dominação humana que leva à exploração e devastação, há diferenças fundamentais quanto à forma como se pretende alcançar esse objetivo (Kirjner \& Kemmerer, 2015). O ativismo vegano critica e propõe discussões em quatro principais linhas de argumentação, conforme exposto por Santana, Santana, e Trajano (2015):

Argumento ecológico: com base, por exemplo, em discussões sobre o desmatamento para a produção de ração para a pecuária, produção esta que corresponde a mais de $70 \%$ de todas as terras destinadas ao plantio no mundo. Além disso, por exemplo, há o argumento do desperdício, uma vez que cada quilo de carne bovina consome cerca de 15 mil litros de água (Chapagain \& Hoekstra, 2008) e a questão do efeito estufa, causado pela emissão de gases pelo gado. Nesta categoria de argumentação, portanto, reside a crítica aos argumentos preservacionistas de sustentabilidade ambiental; 
Argumento econômico: parte do fato de que um terço dos grãos produzidos no mundo são destinados à alimentação do gado, justificando em muitos casos a fome em países produtores de grãos exclusivamente para exportação, em detrimento de sua população, condenada a consumir produtos caríssimos advindos da importação. Além disso, há também o desperdício, visto que no espaço e tempo onde se produz 210 quilos de carne - ou apenas um boi -, é possível colher 34 toneladas de milho, 19 toneladas de arroz ou 32 toneladas de soja. Aqui, cabe também críticas ao sistema capitalista, que permite a objetificação dos animais em produtos, geradores de lucro e, portanto, alvo de exploração;

Argumento de saúde pública: disserta sobre a obesidade gerada pela adoção de dietas baseadas em farinha branca, açúcares refinados e carne - que tem sua produção e venda barateados por políticas de produção voltadas ao mercado da pecuária. Aqui se enquadra o grande motivo de adesão ao veganismo por boa parte de seus praticantes. Estudos apontam que quando o veganismo é adotado por razões de saúde, a permanência na prática é menos duradoura (Radnitz et al., 2015);

Argumento político: que trata da relevância da dieta vegetariana na legitimação da luta pelos direitos animais. Neste quesito reside outro grande motivo para a prática do veganismo, que é o combate à exploração e crueldade animal. É, portanto, nesta categoria que se encaixam as posturas de buycott e questionamento social característicos do veganismo.

Ativistas pelos direitos animais buscam, portanto, a mudança de comportamento a partir da quebra de paradigma socioeconômico a favor do fim da exploração animal, promovendo um estado de equilíbrio interespecífico igualitário, fundamentado no antiespecismo. Ao contrário, o ecoativismo busca a manutenção sustentável e responsável dos ecossistemas, respeitando a expansão humana, 
advogando a favor do progresso e adaptação dos biomas às necessidades sociais, ao mesmo tempo em que propõe recuperar organizadamente o que já foi devastado (Kirjner \& Kemmerer, 2015). Ou seja, a fronteira que divide esses dois movimentos é óbvia à medida em que se reconhece a fragilidade do termo "sustentável", pois a crítica vegana em sua inserção no movimento pelos direitos animais é, exatamente a de que a expansão humana é incompatível com a preservação ambiental e, portanto, insustentável.

Concluindo, as raízes comuns com movimentos sociais ambientalistas, o estilo de vida vegetariano e posturas político-econômicas anti-capitalismo podem fazer com que as representações sociais dos não veganos sobre o movimento vegano sejam enviesadas, tornando sua construção distante do que é, de fato, a realidade desse grupo para seus integrantes. A recente popularização da ideologia pode estar influenciando e transformando a representação social dos veganos no Brasil e, portanto, o presente estudo pretende gerar conhecimento teórico e prático sobre movimentos sociais por meio de suas representações sociais.

\section{Objetivos}

\section{Principal}

Acessar, descrever e analisar as representações sociais construídas por veganos sobre o próprio veganismo.

\section{Secundários}

Discutir a inserção social dos veganos, a forma como se estrutura seu ativismo e como percebem sua experiência social não hegemônica. 


\section{Método}

\section{Participantes}

Ao todo, 81 participantes veganos de um congresso de direitos animais VegFest 2015 -, bem como via questionário online, foram selecionados por conveniência para participar desta pesquisa. Os dados provenientes das duas formas de acesso aos participantes (44 presenciais e 37 online) foram reunidos para atingir o critério de número mínimo de participantes -70 respondentes - para análises de evocação de palavras. Além disso, neste mesmo congresso foi realizada uma sessão de grupo focal com cinco participantes veganos, buscando compreender o porquê de sua escolha vegana, o sentido de seu ativismo, como acreditam que são avaliados pelos "outros" e como se comportam diante de casos em que se sentem discriminados ou desvalorizados por sua escolha. Todos os participantes consentiram livre e esclarecidamente com a participação (Anexo 1).

\section{Instrumentos}

Questionários. Foi elaborado um questionário composto por duas partes: questionário sociodemográfico e questionário de evocação de palavras (Anexo 2). Tanto nos momentos em que a abordagem foi presencial, quanto online, o questionário continha o mesmo conteúdo e teor das questões, tendo como distinção apenas o layout.

As questões visavam acessar o perfil sociodemográfico dos participantes, tendo em vista a representatividade da amostra e a caracterização do movimento social vegano brasileiro em termos de sua composição individual. Dados estatísticos do único portal brasileiro que pratica o censo populacional de vegetarianos e veganos indicam haver cerca de 5 milhões de veganos no Brasil, representando 28,5\% do total de vegetarianos (Mapa Veg, n.d.), que já somam 8\% da população nacional (IBOPE, 2012). Revela ainda haver maior concentração desses grupos na região sudeste do Brasil. Dados como 
sexo, faixa etária ou tempo de prática da ideologia vegana estão indisponíveis em outras fontes, mas foram incluídos no questionário. Por fim, uma questão que pedia para o participante localizar numa escala Likert de 4 pontos sua concordância ou discordância sobre considerar-se ativista.

O questionário de evocação de palavras para veganos que, por sua vez, representa o instrumento de acesso às representações sociais em si, consistia de um termo indutor ("ser vegan") e pedia para que o participante listasse as 5 primeiras palavras ou ideias que surgissem em suas mentes relacionadas a esse termo. Em seguida, solicitou-se que escolhessem e justificassem, dentre as evocações listadas, a que fosse mais representativa do significado do termo indutor em suas opiniões.

Grupo focal. Reconhecida como uma importante técnica de coleta de dados em pesquisas qualitativas, o grupo focal se configura como um grupo de discussão informal e de tamanho reduzido, com o propósito de obter informações de caráter qualitativo em profundidade. Por sua característica fundamentalmente dialética, esta técnica intensifica o acesso às informações sobre fenômenos-alvo pela possibilidade de dar origem a novas concepções, uma vez que analisa uma ideia em profundidade - alcançada pelo trabalho em equipe por parte dos participantes (Backes, Colomé, Erdmann, \& Lunardi, 2011). A técnica é fundamentada no pressuposto de que as pessoas tendem a formar opiniões e atitudes na interação com os outros, sugerindo que os dados não possuem o viés de questionários ou entrevistas, onde o participante é convocado a emitir opiniões sobre assuntos que talvez nunca tenha refletido anteriormente, além de atenuar os efeitos da desejabilidade social.

Não há consenso sobre o mínimo total de participantes para que um grupo focal seja bem sucedido, porém, conforme afirma Marková (2003), é possível obter sucesso com a técnica a partir de um mínimo de quatro participantes e um máximo de quinze, 
além do pesquisador e um assistente de pesquisa. No presente estudo, participaram cinco indivíduos, dois do sexo masculino e três do sexo feminino. 


\section{Procedimentos}

Questionários. O acesso aos dados provenientes da população vegana se deu em visita ao congresso VegFest 2015, realizado na cidade de Recife/PE, nas dependências da Universidade Federal de Pernambuco - UFPE, onde foram aplicados aos participantes que voluntariamente se dispuseram a responder os questionários. Após o encerramento do congresso, o questionário foi fielmente reproduzido e disponibilizado online na plataforma Survey Monkey e, subsequentemente, sua divulgação foi feita a partir do envio do link de acesso por email, postagens em grupos de veganos em redes sociais e pela estratégia da "bola de neve" em diversos meios.

Grupo Focal. No mesmo congresso citado anteriormente, foi realizada uma sessão de grupo focal com cinco veganos, na presença de uma assistente de pesquisa devidamente instruída do procedimento, o qual teve duração de uma hora e obedeceu um roteiro semi-estruturado de questões centrais para os objetivos da pesquisa. Todos os participantes eram estimulados a participar e contribuir com todas as questões. O áudio foi gravado e transcrito no processador de textos do pacote Office. As expressões e gírias que foram utilizadas no discurso foram removidas para evitar interferências, bem como a gramática foi padronizada e o dicionário da análise passou por revisão criteriosa, para reunir termos semelhantes sob um mesmo radical.

Análise de dados. A análise dos dados demográficos foi realizada no software Microsoft Excel 2016, para a produção de gráficos e figuras ilustrativas. Os dados do questionário de evocação, bem como do grupo focal foram analisados pelo software Iramuteq (Interface de R pour les Analyses Multidimensionnelles de Textes et de Questionnaires), um software gratuito e com fonte aberta que permite fazer análises semânticas sobre corpus textuais e sobre tabelas de indivíduos/palavras. Todas as respostas foram transcritas para os processadores de dados dos pacotes OpenOffice ou 
Libre Office. Para que fossem processados separadamente, cada participante recebeu um código numerado $\left(* * * * * \mathrm{R} \_\mathrm{n}^{\mathrm{o}}\right.$ do participante) na codificação textual, com exceção do grupo focal, no qual todas as respostas foram agrupadas em uma variável única, para refletir a fala do grupo como uma só voz.

As cinco palavras evocadas por cada sujeito foram organizadas em uma tabela e submetidas à análise de matrizes pelo software Iramuteq, que organiza as evocações por frequência e ordem de evocação, de acordo com a teoria do núcleo central (Abric, 1976). Evocações mais frequentes e localizadas entre as primeiras evocações serão alocadas no quadrante representativo do núcleo central, enquanto as menos frequentemente evocadas, e/ou evocadas por último, formarão os sistemas periféricos da representação social. O cálculo final é realizado pela média ponderada entre os fatores "frequência" e "ordem de evocação". Na matriz, o primeiro quadrante (superior, à esquerda) representa o núcleo central da representação, onde residem os valores mais rígidos e perenes; a primeira periferia (superior, à direita) confere proteção ao núcleo, sendo mais flexível e adaptável às experiências e contextos nos quais os indivíduos participam. Os elementos contrastantes (inferior, à esquerda) são variações da representação características de seus subgrupos, mas que reforçam o núcleo central, ou seja, representam pontos de vista diferentes e transições entre representações. Por fim, a segunda periferia (inferior, à direita), também representa uma região de troca, de valores que estão sendo negociados pelos indivíduos em sua experiência social.

Tanto as falas que justificam a escolha de uma das evocações como mais relevante, quanto a fala do grupo focal, foram analisadas pelo mesmo software, porém o conteúdo do grupo focal foi submetido a uma classificação hierárquica descendente (CHD) simples. Essa análise gera classes de segmentos de texto (ST) que apresentam os contextos em que termos foram evocados com proximidade entre si com frequência 
relevante e isolados o suficiente para serem diferentes dos ST das outras classes (Camargo \& Justo, 2013). A análise lexical, além de evidenciar tipos diferentes de discursos utilizados pelos participantes da pesquisa, permite - pelo uso das UCEs que se categorize o conteúdo da fala (A. R. A. do Nascimento \& Menandro, 2006), de forma equivalente à análise de conteúdo de Bardin (1977).

Em maior profundidade, a análise realizada pelo software Iramuteq para corpos de texto (corpus) utilizando o método da CHD realiza alguns cálculos sobre a coocorrência de palavras em ST, buscando distinguir classes de palavras que representem as diferentes abordagens do discurso sobre o tópico investigado. “As classes geradas a partir da CHD representam o contexto de sentido das palavras e podem apontar representações sociais ou elementos de representações sociais sobre o objeto social estudado" (Castro, Papaleo Koelzer, Vizeu Camargo, \& Barbará S. Bousfield, 2014, p.209). O pressuposto é que pontos de vista diferentes produzem diferentes discursos e o uso de um vocabulário específico sobre um objeto se torna um meio para identificar maneiras diferentes de pensá-lo. O objetivo da análise pela CHD, portanto, "é distinguir classes de palavras que representam diferentes formas de discurso a respeito do tópico de interesse" (Kronberger \& Wagner, 2002, p.427).

O processo analítico consiste de algumas etapas: (1) leitura e produção do dicionário, onde o programa estabelece a Unidade de Contexto Inicial (UCI), que corresponde ao corpus inteiro a ser fragmentado. Nesse momento é gerado o dicionário da análise, que deve ser revisado e editado de forma a verificar se a lematização estabelecimento de uma unidade radical para cada termo, que o une a seus semelhantes -, bem como se a classificação gramatical está adequada. A seguir, (2) a UCI é fragmentada em Unidades de Contexto Elementar (UCE), definida segundo critérios estabelecidos pelo pesquisador de tamanho do ST e pontuação. "É a partir do 
pertencimento das palavras de um texto a uma UCE, que o programa vai estabelecer as matrizes a partir das quais será efetuado o trabalho de classificação" (Reinert, 1998, p. 17). Nessa etapa, a análise consiste na busca pela associação frequente entre termos, de forma a isolá-los em classes. É de responsabilidade do pesquisador encontrar o número de classes ideal para seu corpus, de modo que ao menos $75 \%$ dele seja utilizado na produção das classes, bem como que seja possível identificar categorias de conteúdo que não se sobreponham. Os termos constituintes de cada classe são classificados de acordo com o Chi-quadrado $\left(\chi^{2}\right)$ de associação dos radicais às suas respectivas classes, permitindo que elas sejam categorizadas de acordo com as UCE que a compõem. Nesta etapa, é indicado selecionar quais as classes gramaticais a serem consideradas como ativas no discurso, de forma a limpar os dados. "A lógica é trabalhar com os elementos de linguagem 'plenos' como ativos: adjetivos, formas não reconhecidas, nomes (substantivos), verbos; e com nomes (substantivos) e verbos auxiliares como complementares (suplementares); eliminando as "palavras instrumento"' (Camargo \& Justo, 2013). Especificamente no presente estudo, como houve edição ao dicionário, todas as formas não reconhecidas foram devidamente designadas a suas classes gramaticais correspondentes, bem como a lematização foi adequada.

Entre os outputs gerados pela análise, destacam-se a Análise Fatorial de Correspondências (AFC) e o dendograma. A AFC consiste na representação gráfica cartesiana da proximidade - ou oposição - entre classes. Nesta análise é possível, portanto, inferir quais tipos de discursos representam pontos de vista semelhantes ou não, bem como suas relações de tensão ou coerência, a partir de sua localização no plano. O dendograma, por sua vez, é um diagrama de árvore representativo das classes e denota a estrutura de derivação entre elas - que corresponde ao valor de $\chi^{2}$ representativo dessa relação (com relação $=0$ na origem $)$-. Além disso, evidencia, 
em porcentagem, a parcela do corpus que cada classe representa e traz as palavras mais representativas (de maior $\chi^{2}$ ) dentre as UCEs de cada uma.

\section{Resultados e discussão}

\section{Dados demográficos}

Ao todo, 81 veganos de 15 Estados, além do Distrito Federal, responderam ao questionário, dos quais 72,84\% são do sexo feminino (Figura 1); 2,47\% (menores de 18 anos), $25,93 \%$ ( entre 19 e 23 anos), 24,69\% ( entre 24 e 28 anos) e 46,92\% (nas faixas de 29 a 33 e acima de 34) (Figura 2); 58,03\% com Ensino Superior completo ou em curso (Tabela 2); 76,54\% possuem renda própria (Tabela 3); 30,86\% são veganos há mais de 4 anos (Tabela 4); e a partir da escala Likert de 4 pontos, 76,54\% concordam/concordam plenamente que são ativistas $(\bar{x}=3,0, D P=0,72)($ Tabela 5$)$.

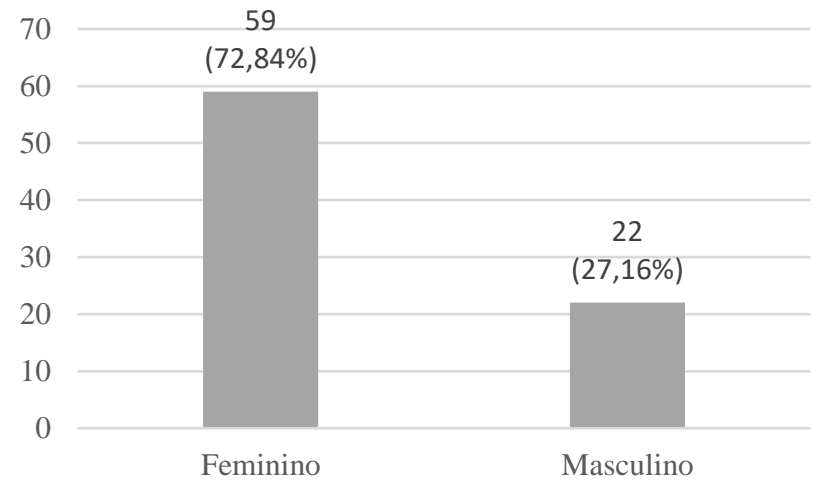

Figura 1. Número absoluto e porcentagem relativa de participantes por sexo biológico.

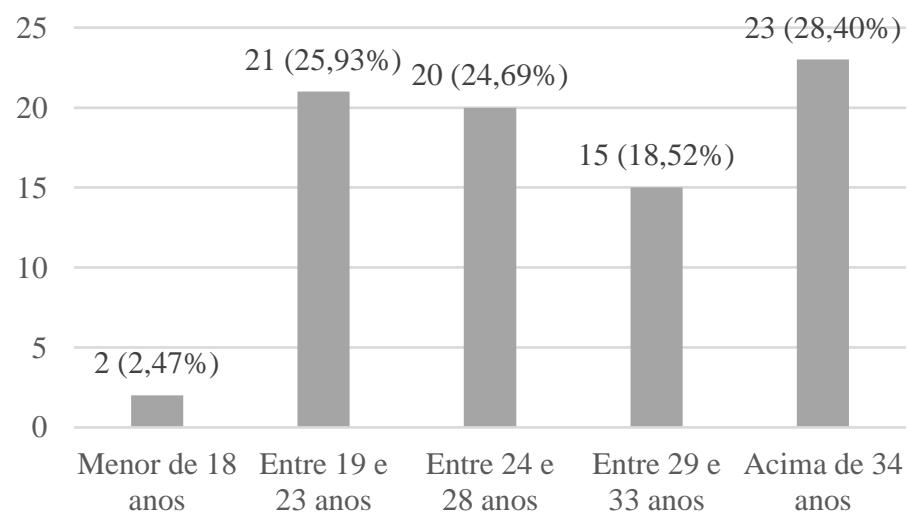

Figura 2. Distribuição percentual dos participantes por faixa etária 
Tabela 2. Grau de escolaridade dos participantes

\begin{tabular}{lll} 
Grau de escolaridade & Total & $\%$ \\
\hline Ensino Fundamental completo & 1 & 1,23 \\
Ensino Fundamental incompleto & 0 & 0 \\
Ensino Médio completo & 0 & 0 \\
Ensino Médio incompleto & 3 & 3,70 \\
Ensino Superior completo & 19 & 23,46 \\
Ensino Superior incompleto & 28 & 34,57 \\
Pós-graduação / Mestrado / Doutorado completo & 13 & 16,05 \\
Pós-graduação / Mestrado / Doutorado incompleto & 17 & 20,99 \\
\hline Total Geral & 81 & 100
\end{tabular}

Tabela 3. Renda dos participantes

\begin{tabular}{llll} 
Qual sua renda pessoal? & Total & $\%$ \\
\hline Não possuo renda pessoal & 19 & 23,46 \\
Menos de 1 salário mínimo (Abaixo de R\$ 788,00) & 15 & 18,52 \\
Entre 1 e 4 salários mínimos (Entre R\$ 789,00 e R\$ 3151,00) & 22 & 27,16 \\
Entre 4 e 6 salários mínimos (Entre R \$ 3152,00 e R \$ 4728,00) & 7 & 8,64 \\
Acima de 6 salários mínimos (Acima de R\$ 4729,00) & 18 & 22,22 \\
\hline Total Geral & 81 & 100
\end{tabular}

Tabela 4. Tempo de veganismo dos participantes

\begin{tabular}{lll} 
Tempo de veganismo & Total & $\%$ \\
\hline Menos de 6 meses & 12 & 14,81 \\
Entre 6 meses e 1 ano & 10 & 12,35 \\
Entre 1 e 2 anos & 15 & 18,52 \\
Entre 2 e 3 anos & 19 & 23,46 \\
Acima de 4 anos & 25 & 30,86 \\
\hline Total Geral & 81 & 100
\end{tabular}

Tabela 5. Respostas à escala Likert de 4 pontos sobre autoavaliação de ativismo.

\begin{tabular}{lll} 
"Me considero um ativista vegan" & Total & $\%$ \\
\hline Discordo Plenamente & 1 & 1,23 \\
Discordo & 18 & 22,22 \\
Concordo & 42 & 51,85 \\
Concordo Plenamente & 20 & 24,69 \\
\hline Total Geral & 81 & 100
\end{tabular}

A predominância de indivíduos com níveis de instrução mais elevados reflete tanto a origem acadêmica da ideologia vegana, quanto traços da cultura brasileira em relação ao consumo de produtos industrializados, onde a mera presença de um rótulo pressupõe seu encarecimento. No Brasil, o consumo de produtos não industrializados é 
pequeno (Pomeranz, 1977) e, portanto, a prática da alimentação vegetariana estrita no veganismo - mantidas as características culturais de consumo - se torna bastante dispendiosa e, consequentemente, restritiva. Foi possível observar a preocupação dos participantes da pesquisa com essa questão durante a execução do grupo focal:

“[...] a população tem o costume de consumir muitos produtos industrializados. Quando baixa a qualidade, baixa o preço. Então é uma mudança muito grande de hábitos. Pra uma pessoa que come tudo com soro de leite que é barato, pensar em ser vegano causa essa dúvida sobre o que se vai comer. Isso reforça o mito de que ser vegano é caro" (Participante 05)

Além disso, há nessa população, uma maioria de indivíduos do sexo feminino, reproduzindo outros achados de distribuição de veganos no mundo, “os quais tendem a ser mulheres, com apenas uma minoria (cerca de 30\%) de homens" (Sobal, 2005, p. 140). Historicamente, além de estarem associadas a comportamentos mais compassivos e empáticos, mulheres são mais associadas à lida com o alimento, desde a escolha do que deve ser trazido ao lar, até a tarefa de cozinhar as refeições. Para os homens, o contato com o alimento (seja ele advindo da caça, ou não) se deu historicamente como demonstração de dominância, masculinidade predatória e reafirmação de poder social (Adams, 2015; Adamson, 2004; Berndsen \& Pligt, 2004; Carlin \& Rosenthal, 1998; Gelfer, 2013; Rothgerber, 2013; Sobal, 2005; Tobin, 1999; Torres \& Allen, 2006). O veganismo tem como característica, entre outras coisas, o maior contato com a matériaprima da alimentação e o distanciamento da indústria alimentícia tradicional, o que pode predispor o afastamento do público masculino pela própria construção social contemporânea do papel doméstico. O viés de gênero se faz presente na população vegana, entre outros fatores, na medida em que ser vegano implica um contato mais 
direto e uma escolha mais criteriosa e consciente dos produtos, pois essas seriam “tarefas femininas". Outro fator é que o consumo de produtos denominados "sem crueldade" também representa uma afronta à masculinidade, conceito construído sobre seu potencial de destruição, agressividade e dominação. Portanto, é esperado que haja mais mulheres neste grupo, pois o consumo de produtos "com crueldade" reafirma o conceito humano de masculinidade.

A escala Likert sobre ativismo denota a fundamentalidade do ativismo para essa população. A prática vegana cotidiana é, em si, uma forma de resistência (Argolo, 2008; Chatterton \& Pickerill, 2010; Scott, 2000; Véron, 2016) e esse enfrentamento pode vir nas mais diversas formas: desde protestos públicos, postagens em redes sociais, abstenção do consumo de determinadas marcas, até mesmo num prato de comida. Assim, é seguro sugerir que o veganismo é intrínseco ao seu ativismo.

\section{Questionário de evocação de palavras}

O resultado da análise de evocação (Tabela 6) revela, em seu núcleo central, as seguintes palavras que, provavelmente, constituem a porção mais rígida e normativa da representação social dos veganos: ética, respeito, compaixão, saúde, igualdade, animais, liberdade e libertação animal. É possível reconhecer nestas evocações duas categorias de termos, normativos - ética, respeito, compaixão, igualdade, liberdade - e funcionais animais, saúde e libertação animal. Há, portanto, a ideia de que, para se tornarem plenamente humanos, os veganos acreditam ser necessário considerar os animais como iguais em seu direito à vida e liberdade e isso é praticado por eles utilizando os elementos normativos como guia para seu comportamento. Esse posicionamento está presente nas falas que justificam as evocações: “A prática diária do boicote a qualquer estrutura que envolva exploração animal deve ser pautada pela ética, para que haja um real compromisso com a causa. É o fundamento primordial àquele que se considera vegano. 
Ter uma postura crítica firme e bem embasada" (Participante $\mathrm{n}^{\circ} 47$ ); "Entendo o veganismo como a prática de uma ideologia que reúne ideais de promoção da abolição da exploração dos animais, por reconhecer neles as mesmas características que garantem aos humanos um direito natural à vida, à liberdade e a uma integridade física e psíquica” (Participante n49); “Libertação Animal é a ideia que representa o veganismo, pois muito além da dieta e do consumo consciente, o veganismo é um movimento político em prol da libertação de todos os animais, inclusive os humanos" (Participante $\mathrm{n}^{\circ} 11$ )

A primeira periferia e os elementos contrastantes formam o sistema periférico da representação, sendo esta a parte mais flexível e dependente de contextos e experiências. Assim, nesse sistema periférico é possível observar e acessar processos de mudança nas representações sociais. Na primeira periferia - com termos de maior importância e frequência - constam os termos: amor, empatia, consciência, sustentabilidade e meio ambiente. Já nos elementos contrastantes da periferia - com menor frequência e importância - constam: abolicionismo, alimentação, justiça, direitos animais, reflexão, crueldade, especismo, respeito à natureza e libertação.

Novamente, é possível categorizar os termos em normativos - amor, empatia, consciência, sustentabilidade, abolicionismo, justiça, reflexão, crueldade, respeito à natureza e libertação, e funcionais - meio ambiente, alimentação, direitos animais e especismo. Nota-se que alguns dos elementos se assemelham muito aos do núcleo central, porém, esse tipo de fenômeno é esperado, uma vez que o núcleo central e as periferias formam o sistema da representação social. Ou seja, os sistemas se complementam para formarem, juntos, a representação social de fato (Sá, Vetere, Castro, Oliveira, \& Carvalho, 2009, conforme citado em Barros, 2015).

A análise do sistema periférico da representação social revela que, na relação social, os veganos trazem consigo a postura universalista de buscar a igualdade e 
equilíbrio da atividade humana com a preservação da natureza através de valores de autotranscendência, como nas falas: "Ser vegan é uma atitude de amor, é amor na prática, é uma questão de estado de consciência, quebra de prisões mentais, liberdade, autonomia e autogestão" (Participante n³2); "Acredito que o ato de amar verdadeiro basta para trazer todos os beneficios lindos para os seres da Terra. Ao amar, todo sentimento de posse ou domínio sobre outras espécies é quebrado e o desejo que predomina é retribuir esse amor, permitindo a liberdade, felicidade e paz a tudo que habita a Terra". (Participante no38); "Porque o amor é tudo! A partir do amor ao próximo (qualquer ser vivo) todas as outras palavras, qualidades, atitudes são pensadas e feitas para um bem maior" (Participante n"55); "ser vegan é uma forma de amar independente da espécie" (Participante $\left.\mathrm{n}^{\circ} 45\right)$.

Por fim, a segunda periferia, a mais distante do núcleo central "representa as mudanças recentes na estrutura e hierarquia das representações sociais” (Barros, 2015, p. 76). Nesta região encontram-se as palavras evocadas por último e com menor importância: natureza, paz, espiritualidade, felicidade, vida, luta, bem estar, direitos, comida, boicote, evolução, não violência, solidariedade, equilibrio, sensibilidade, batalha, nutrição, interseccionalidade, política, preservação ambiental, escolha, ecologia, alteridade e ativismo. Novamente, categorizados entre normativos - paz, espiritualidade, felicidade, vida, não violência, solidariedade, equilibrio, sensibilidade, política e alteridade - e funcionais - natureza, luta, bem estar, direitos, comida, boicote, evolução, nutrição, interseccionalidade, preservação ambiental, escolha e ecologia.

Esta zona de transformação corrobora a suposição de que o aspecto político do veganismo tem construção recente na sociedade brasileira, presente nas falas: “A luta contra uma opressão que seu si não padece diretamente precisa de formas potencializadas de empatia para se preocupar com quem não pode se defender, 
reconhecer a alteridade para além de sua espécie e seus domínios é um exercício diário de reanálise e transformação de suas atitudes" (Participante $\left.\mathrm{n}^{\circ} 44\right)$; “A luta pelos direitos animais é o que sustenta minha existência" (Participante n³7); "O que me levou até o veganismo foram as minhas outras lutas pelas minorias e por ser uma minoria, com o tempo percebi que não havia ética em defender um tipo de vida e não defender todos" (Participante nº76); Além disso, é perceptível que o veganismo tem se difundido bastante entre pessoas de fé espiritualista, uma vez que o endosso de valores universalistas está relacionado a atitudes de consciência alimentar, assim como observado por Dreezens, Martjin, Tenbült, Kok e de Vries (2005), nas falas “nos 10 mandamentos da lei de Deus o primeiro é Amar a Deus sobre todas as coisas e ao próximo como a si mesmo e para mim os animais também estão incluídos nesta lei e não precisamos matar nenhum animal para sobreviver" (Participante $\left.\mathrm{n}^{\circ} 19\right)$; “O universo é um. Somos células dele. Estou em todos os seres. Todos os seres estão em mim" (Participante n56). 
Tabela 6. Matriz de coocorrências dos termos evocados pelos participantes (EvocaçãoFrequência-Ranking médio).

\begin{tabular}{|c|c|c|}
\hline \multicolumn{3}{|c|}{$\leq 2,84$ Ranking $>2,84$} \\
\hline & Núcleo Central & Primeira Periferia \\
\hline & Ética $-22-2,5$ & Amor $-24-3$ \\
\hline & Respeito $-19-2$ & Empatia $-13-3$ \\
\hline & Compaixão $-17-2,2$ & Consciência $-9-3,4$ \\
\hline & Saúde $-16-2,8$ & Sustentabilidade $-5-4,2$ \\
\hline & Igualdade $-12-2,5$ & Meio Ambiente $-6-3,3$ \\
\hline & Animais $-12-2$ & \\
\hline & Liberdade $-9-2,2$ & \\
\hline & Libertação Animal - 9-1,7 & \\
\hline & Elementos Contrastantes & Segunda Periferia \\
\hline & Abolicionismo $-5-2$ & Natureza $-5-3,8$ \\
\hline & Alimentação - 3-1,3 & $\mathrm{Paz}-5-3,2$ \\
\hline & Justiça $-3-2,7$ & Espiritualidade $-5-4$ \\
\hline$\hat{n}$ & Direitos Animais $-2-1,5$ & Felicidade $-5-4,2$ \\
\hline$\wedge 1$ & Reflexão $-2-2$ & Vida $-4-4$ \\
\hline 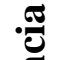 & Crueldade $-2-2,5$ & Luta $-4-3,5$ \\
\hline ब्ष & Especismo $-2-1,5$ & Bem Estar $-3-4,3$ \\
\hline & Respeito à Natureza - 2 -2 & Direitos $-3-3$ \\
\hline 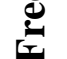 & Libertação $-2-2$ & Comida $-3-3,7$ \\
\hline 吉 & & Boicote $-3-3,3$ \\
\hline in & & Evolução $-3-3,3$ \\
\hline & & Não Violência - 3-4,3 \\
\hline & & Solidariedade $-3-4$ \\
\hline & & Equilíbrio $-2-4,5$ \\
\hline & & Sensibilidade $-2-3$ \\
\hline & & Batalha $-2-3$ \\
\hline & & Nutrição $-2-4$ \\
\hline & & Interseccionalidade $-2-3$ \\
\hline & & Política $-2-3$ \\
\hline & & Preservação Ambiental - 2 - 3,5 \\
\hline & & Escolha $-2-3$ \\
\hline & & Ecologia - 2-4 \\
\hline & & Alteridade $-2-4$ \\
\hline & & Ativismo $-2-5$ \\
\hline
\end{tabular}

A CHD realizada com as falas proferidas para justificar a escolha da evocação mais pertinente gerou 3 classes (Tabela 7). Dos 87 ST, 82 puderam ser analisados (94,25\%). A primeira classe, representando $47,6 \%$ de todos os ST, ao agrupar os termos “animal”, “ética", “compaixão", "libertação", "veganismo”, entre outros, revela haver um tema predominante no discurso da representação social relativo ao aspecto político do que é "ser vegano". Este resultado corrobora o encontrado na análise de evocações, 
uma vez que este aspecto se revelou nuclear na representação social desse grupo. A centralidade desse discurso se vê presente nas falas dos participantes, reforçando a intrinsecidade do ativismo na ideologia vegana.

É perceptível, portanto, a centralidade do aspecto político, filosófico e contracultural de não conformidade no veganismo, como defendido por Argôlo (2008). Está no cerne dessa ideologia buscar ativamente a igualdade de direitos entre humanos e não humanos, denunciar as práticas predatórias e ambientalmente prejudiciais do sistema socioeconômico contemporâneo e agir conscientemente contra o status quo, em desobediência.

A segunda classe, com 31,7\%, agrupou termos como "mundo, "consciência", “planeta" e "processo". O segundo discurso mais presente na representação social dos veganos, portanto, traz o aspecto idealista da proposta vegana, a esperança de criar um mundo melhor, a solução dos argumentos ecológico, de saúde, político e econômico. Nas falas dos participantes, é perceptível a seriedade com que eles tratam do tema, refletindo características nômicas heterodoxas de uma minoria ativa:

"Ser vegano é viver com a consciência de que há um mundo melhor e que atitudes assim nos levarão até ele" (Participante n80)

"Ter consciência da senciência animal (capacidade de sentir dor, medo, afeto) nos impõe o dever moral de os proteger do sofrimento e da exploração humana" (Participante $\mathrm{n}^{\circ} 67$ )

"Ser vegano é uma escolha de vida, muito além de alimentação, roupas. A busca por um mundo igualitário, para todos os animais, inclusive seres humanos, independentemente de credos, raças, gênero ou qualquer outro 
estereótipo social, um cuidado com a natureza, uma consciência de coletividade" (Participante $\left.\mathrm{n}^{\circ} 12\right)$

A terceira e última classe, com os $20,73 \%$ dos ST, reuniu os termos "vegan", “amor", "próximo", “espécie” e "liberdade”. Apenas na terceira e menor parcela do discurso dos participantes está presente o que se encontra no núcleo central da representação:

"Ser vegan é uma atitude de amor, é amor na prática, é uma questão de estado de consciência, quebra de prisões mentais, liberdade, autonomia e autogestão" (Participante $\left.\mathrm{n}^{\mathrm{0}} 32\right)$

"Acredito que o ato de amar verdadeiro basta para trazer todos os beneficios lindos para os seres da Terra. Ao amar, todo sentimento de posse ou domínio sobre outras espécies é quebrado e o desejo que predomina é retribuir esse amor, permitindo a liberdade, felicidade e paz a tudo que habita a Terra". (Participante n³8)

"Porque o amor é tudo! A partir do amor ao próximo (qualquer ser vivo) todas as outras palavras, qualidades, atitudes são pensadas e feitas para um bem maior" (Participante $\left.\mathrm{n}^{0} 55\right)$

Apesar de ser central para a representação, o discurso autotranscendente de amar o próximo, independente da espécie, foi escolhido como mais importante em uma quantidade reduzida de casos, quando em comparação com outros termos. Essa disparidade pode refletir, novamente, o distanciamento do que é considerado fundamental na teoria para o que é, de fato, praticado pelos veganos. 
Tabela 7. Dendograma da CHD realizado com as justificativas dadas às evocações selecionadas pelos participantes ordenado por valor de $\chi^{2}(p \leq 0,05)$.

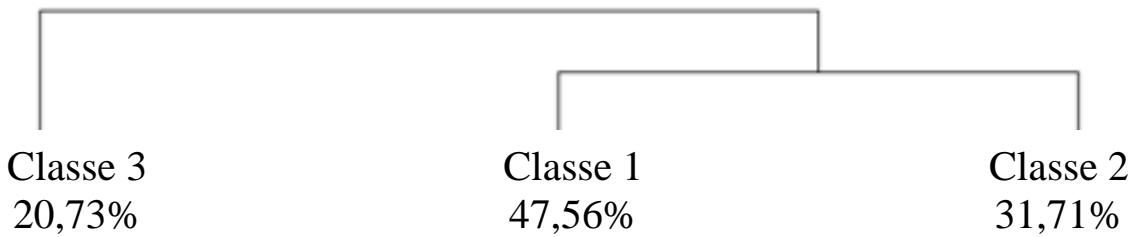

\begin{tabular}{|c|c|c|c|c|c|}
\hline Lema & $\chi^{2}$ & Lema & $\chi^{2}$ & Lema & $\chi^{2}$ \\
\hline Amor & 38,37 & Animal & 17,65 & Mundo & 12,27 \\
\hline Vegan & 20,36 & Ética & 9,57 & Planeta & 10,31 \\
\hline Só & 16,08 & Veganismo & 8,44 & Consciência & 10,31 \\
\hline Próximo & 16,08 & Direito & 7,14 & Importante & 9,06 \\
\hline Amar & 16,08 & Libertação & 5,87 & Sentir & 9,06 \\
\hline Vivo & 11,91 & Compaixão & 5,34 & Processo & 9,06 \\
\hline Espécie & 11,38 & & & Melhor & 7,97 \\
\hline Precisar & 7,54 & & & Humano & 7,28 \\
\hline Domínio & 7,54 & & & Dor & 5,73 \\
\hline Atitude & 7,54 & & & Estar & 5,73 \\
\hline Independente & 4,0 & & & Pessoa & 5,58 \\
\hline Animal & $-8,98$ & Mundo & $-10,33$ & Amor & $-7,17$ \\
\hline Veganismo & $-6,03$ & Consciência & $-6,94$ & Ética & $-5,9$ \\
\hline \multirow[t]{7}{*}{ Respeito } & $-4,04$ & Planeta & $-6,94$ & & \\
\hline & & Amor & $-6,41$ & & \\
\hline & & Empatia & $-5,87$ & & \\
\hline & & Estar & $-4,83$ & & \\
\hline & & Vegan & $-4,83$ & & \\
\hline & & Espécie & $-4,83$ & & \\
\hline & & Dor & $-4,83$ & & \\
\hline
\end{tabular}

A Figura 3 representa a AFC das formas ativas do discurso. Pode-se observar que é sugerida uma tensão entre as 3 classes da análise. Para ilustrar, os eixos que dividem o gráfico foram nomeados, dividindo os dados entre "elementar/transcendente", ou "Comportamento/Consciência". O eixo horizontal divide as classes 1 e 2, denotando tensão entre a causa política de libertação animal prática e a noção de que se deve preservar o meio ambiente. Essa oposição não necessariamente sugere uma disputa entre os temas. Pelo contrário, pode significar clareza de propósito por parte dos participantes, de que ambos são temas elementares, mas que existe uma distinção clara entre prática e teoria. No eixo horizontal, a terceira classe encontra-se 
toda distribuída nos quadrantes relativos a autotranscendência e centrais em relação ao eixo vertical.

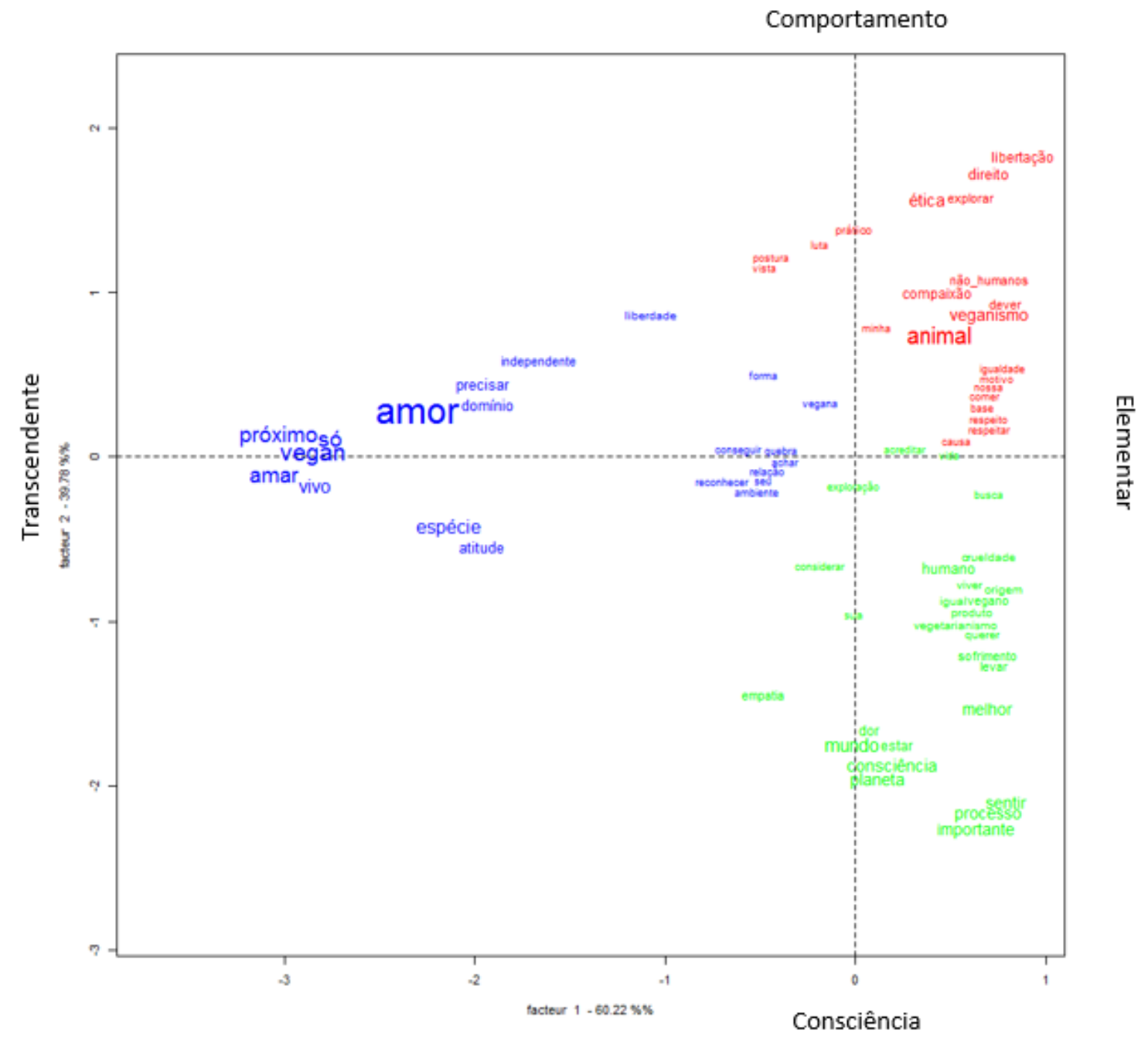

Figura 3. Análise fatorial de correspondência das formas ativas no discurso de justificação da escolha do termo mais relevante no questionário de associação de palavras.

Concluindo, a partir da análise do núcleo central e sistemas periféricos das representações sociais dos veganos sobre o veganismo, sugere-se que sua ancoragem seja feita em valores de autotranscendência humana como meio para alcançar um mundo melhor. Buscam, assim, atingir esse objetivo a partir de posturas éticas em relação a todos os seres vivos e quanto aos recursos naturais do planeta. Além disso, foi 
observado que uma parcela desses indivíduos ancora o veganismo como valores formadores de sua prática religiosa ou espiritual. A presença desses elementos na segunda periferia, a mais distante do núcleo central, sugere que esse aspecto tem inserção recente nas representações sociais do veganismo e que, portanto, é um âmbito no qual tem se inserido - provavelmente pelo compartilhamento de valores semelhantes.

\section{Grupo Focal}

A análise lexical subdividiu o corpus textual em 210 segmentos de texto, dos quais $186(88,57 \%)$ puderam ser aproveitados para análise. A organização dos ST por discurso gerou 4 classes (Tabela 8). A primeira, correspondendo a 20,43\% de todos os ST, representa a conceituação do que é o veganismo para os próprios veganos. Nessa classe, foram agrupados discursos com o tema “ser vegano é mais que uma dieta. É uma postura que eu assumo para um mundo que eu quero construir”.

“Toda vez que você fala que é vegano, para quem não está muito familiarizado com o termo, acha que é o mesmo que ser vegetariano, que é só porque você não come leite, ovo. Eu digo que não, não é só isso! O veganismo perpassa várias áreas da vida, desde o que você escolhe para comprar, não necessariamente só em relação aos cosméticos que não foram testados em animais, não é só isso[...]. Eu acho que, no meu caso, eu expandi minha consciência para várias áreas, assim, eu não quero ficar dando o meu dinheiro, gastando o meu dinheiro, com uma empresa que está explorando as pessoas. Pode ser, de repente, que nem tenha ali alguma coisa de origem animal, mas para isso também eu dei uma despertada. Eu estou mais atenta também com tudo que eu consumo". 
"Quando a gente nasce, como ser humano, nos dão consciência do poder de matar seres, causar mal a seres como um todo. Inclusive explorar as forças humanas de forma irracional. Quando você segue a base do veganismo, você deve tentar seguir esse hábito de se diminuir, de tirar o poder de si, esse poder que eu falei, de realizar o mal, causar o mal aos seres, para preservar eles".

"Eu parei de comer carne quando eu era adolescente, quando eu tinha 15 anos, mas aí quando eu comecei a descobrir os impactos da pecuária de modo geral, da produção desses produtos animais de consumo alimentício, no meio ambiente, do desperdício de recurso, nessas coisas, foi como se fosse uma motivação muito política, que era uma época em que estava começando a conhecer essas coisas, adolescente querendo mudar o mundo, querendo um mundo novo".

"O veganismo é um dos esforços que eu faço para tentar construir e dar minha contribuição para construção de um mundo sem opressão. Eu não sei se [esse mundo] vai acontecer ou não, mas no que dependeu de mim, eu tentei fazer o que estava no meu alcance. Eu enxergo que essa foi uma das decisões mais importantes da minha vida, das mais acertadas. Essa coisa de que você tem a consciência dos seus atos, é primordial. A gente nasce numa cultura que ninguém presta atenção em nada, vem só reproduzindo tudo que está sendo feito e a gente não sabe a origem das coisas".

A segunda classe, correspondendo a 20,97\% dos ST, explicita os sentimentos de marginalização que sentem os veganos. Para eles, “o veganismo é menosprezado como uma causa menos importante que outras causas minoritárias". Apesar disso, o próprio 
menosprezo percebido pelos participantes se associa em seu discurso às falas sobre o ativismo.

Como discutido em Pazzini (2014), os veganos - como praticamente todas as minorias sociais - são discriminados e marginalizados pela sociedade. A segunda classe resultante da análise mostra que pouco menos de um quarto do discurso dos veganos sobre o veganismo é direcionado ao sentimento de exclusão social. A discriminação vivida é banalizada como algo indiferente para a causa, como se tivesse pouca influência na vida dos participantes, porém as falas sugerem que é fonte de sofrimento.

"Acho que nos primeiros seis meses você fica irritado, você sofre, até porque você não sabe dar a resposta certa, você não está tão tranquilo com sua decisão, você ainda não conhece todas as coisas".

"Eles colocam uma questão na sua cabeça, você vai refletir sobre isso e vai ter mais certeza do que já tem. Mas você ainda não está muito certo de que você é capaz de dar uma resposta à altura, às vezes as pessoas te tratam com desdém, às vezes você tenta responder e a pessoa nem ouve o que você está falando".

"Você fica muito chateado e acaba querendo não se encontrar mais com aquela pessoa porque ela não te respeita. Mas depois que passa um tempo, que você começa a ter mais convicção daquilo, você consegue pensar que aquela pessoa está se passando por idiota. Eu fico rindo, às vezes eu até deixo a pessoa pagar esse mico, dependendo do assunto até faço uma brincadeira pior, me desmereço ao máximo para encerrar o assunto".

"Eu acho que todo mundo que come carne carrega uma centelha de culpa. Quando você acende essa chama, a pessoa se revolta na sua frente. Ela se 
sente mal! A pessoa fica que nem bicho e passa a se questionar e causa uma briga. A pessoa acha que você está ofendendo ela. Eu digo que não como carne por ter compaixão pelos animais. Aí a pessoa reage achando que eu chamei ela de antiética”.

“Às vezes você não precisa nem falar nada, só a sua presença basta. Às vezes a gente está lá na mesa que está todo mundo comendo e você nem fala nada e já está incomodando o outro, só chega, senta e é ofendido por ser quem você é".

"Eu não gosto quando as pessoas me tratam como um coitado, não sei muito bem lidar com isso. Mas quando as pessoas ficam oferecendo carne, eu digo que não como e pronto. Pois o que me fez tornar vegano foi a firmeza de propósito de um rapaz mais novo que eu, na faculdade. Eu era totalmente carnista, comeria churrasco todo dia se pudesse. Eu cheguei nele e falei que ele era um imbecil por não comer carne, que era frescura, para ele embalar um bife numa folha de alface e comer. Fui muito babaca, muito imbecil, igual essas pessoas que me enchem hoje em dia".

A aparente inofensibilidade do sofrimento parece motivar o ativismo neste grupo. Sofrer dá forças para lutar. Outra vez, é trazida a intrinsecidade do ativismo para o movimento vegano. Nas falas dos participantes, encontra-se evidências de que para além da prática, o comportamento ativo dos veganos direcionado a angariar mais adeptos e mostrar aos outros do que se trata o veganismo é bastante presente no discurso deles.

“O ativismo vegano tem muitos objetivos, seja o ecológico, o político, seja algo intencional, de você desenvolver um físico saudável, defesa aos 
animais, combate ao sedentarismo, tem diversos objetivos. Então ele dá brechas para você seguir o caminho que mais lhe agrada, a sua vocação mesmo, a sua ética, a sua vocação principal. Então, se eu gostar de cozinhar, eu vou cozinhar e ensinar meios de sobreviver a partir da comida, a partir de uma alimentação saudável e gostosa para as outras pessoas que querem ser veganas. Se a pessoa se identifica com salvar os animais de situações de risco, correr riscos fazendo isso, ela fará isso. Tem também as pessoas que querem fazer ações de rua, conscientizando massas, da forma mais rápida e mais eficaz possível através de táticas de comunicação usando o que a gente sofre. A gente pode usar até isso a nosso favor!’.

"De modo geral, a intenção é comunicar quem nós somos, dizer que nós existimos, nós fazemos isso, por causa daquilo. Em seguida, vem [...] receber as pessoas que estão por livre e espontânea vontade querendo fazer uma pergunta para no final você dizer: olha, não faz assim, faz assado $[\ldots] ”$.

"Informar, porque a gente sabe que tem muita gente que está entrando e pergunta o que está acontecendo aqui. Você deve ser aquela pessoa que vai [...] ajudar. Esse é o objetivo do veganismo: mostrar o que é e ajudar as pessoas a tomar os caminhos corretos".

"Dentro do ativismo que eu pratico, eu penso em trazer as pessoas. O objetivo principal mesmo é mostrar para os outros o que o veganismo propõe". 
Já a terceira classe, com 39,25\% dos ST, versa sobre as relações familiares e de amizades, sobre ser aceito e conviver com as diferenças. Nela o tema das falas é centrado em: "no início é muito difícil ser aceito pela família, nós ficamos irritados, as pessoas não acreditam que é uma escolha que vai durar. Só nos respeitam depois de anos de veganismo".

A classe com maior representatividade dentro do discurso sugere que a questão de inserção social é predominante para os participantes. Ser aceito pela família e pelos amigos no momento da transição para o veganismo apresenta-se como um período conturbado, no qual o indivíduo enfrenta bastante preconceito e resistência.

"Eu acho que nunca deixei me atingir, apesar de sempre ter quem diga que por não comer carne eu não terei força para fazer isso ou aquilo. Eu já ouvi um amigo meu reclamando que na universidade, só de engenharia, que as outras pessoas falavam que ele era gay porque ele não comia carne".

"[...] na minha casa, a minha mãe é a que sofre mais porque ela não quer comer carne, mas nas festas de família, em qualquer reunião de família, as pessoas ficam olhando para ela com uma cara horrível porque ela não come carne. Eu acho isso muito ruim! Falei para ela que ela precisa enfrentar isso melhor porque faziam a mesma coisa comigo, de me encarar e perguntar que besteira era essa de não comer carne, se todo mundo come carne, porque eu não comia também. Eu respondia que ninguém era obrigado a comer, nem eles. As pessoas duvidam que você não come carne!"”. 
"Eu sou vegetariano há quase quinze anos e vegano há mais de dez anos, então hoje em dia não tem mais que me convencer. Não tem mais conversa. Uns doze anos atrás, eu falei que estavam de sacanagem comigo em relação a esses eventos de família! Porque eles já viram que eu não vou mudar mais, então, assim, vão me considerar ou vai ficar sempre essa coisa mesquinha? Ai deu uma mudada. Foi muito bom! Se eu não estiver a fim de ir aos encontros de família, eu não vou mais porque tem muitos anos já, acabou”.

"Eu não consegui convencer ninguém da minha família a parar de comer carne, mas convenci um monte de gente fora, um monte mesmo! Mas dentro da minha família ninguém, mas também ninguém me convenceu a voltar para a carne. Então é como se fosse assim: vamos fazer um negócio aqui, respeitando todo mundo! Que me faça sentir incluído. Então, hoje em dia, sempre tem uma coisa ou outra ali para mim e tal. Agora, na época eu era novo, acho que o pessoal ficou esperando eu voltar a comer carne, alguma coisa assim".

"Na época, alguns tinham muitas piadinhas depois vinham com a curiosidade, dai essa coisa do prato de comida também: você leva o prato, aí a pessoa reclama, come reclamando, mas come mais e daqui a pouco acaba a sua comida e é a primeira a acabar! É sempre a primeira a acabar! É a que tem menos e acaba primeiro".

Por fim, a quarta classe, com 19,35\% dos ST, fala sobre a experiência social extrafamiliar, onde dizem que "os ambientes sociais são hostis e pouco adaptados ao veganismo". Refletindo, portanto, o quanto é recente que a sociedade perceba a existência deste grupo de veganos. 
"Hoje em dia é tudo tranquilo, na época tinha um pouco de discriminação sim e muita curiosidade também, mas há quinze anos tinha muito menos informação, também".

"Antes de me tornar vegetariana é como se eu tivesse tido esse processo assim de evolução, e aí eu acabei emagrecendo, sei lá, em cinco dias, eu fiquei extremamente magra. Estava parecendo que eu estava doente e as pessoas estavam fazendo essa ligação com o vegetarianismo, e eu ficava muito irritada porque não era verdade e as pessoas queriam mudar minha ideia, que eu ia morrer ali, e eu sabia que não era isso. Pensaram que devia ser a comida porque eu tinha mudado muito. Eu sabia que tinha outro contexto, mas ninguém entendia isso, isso me deixava muito chateada".

“Ao mesmo tempo, eu tinha 120 quilos. Aí, enquanto para ela diziam que era pelo vegetarianismo que ela estava magra, quando eu apareci magro, também disseram que foi o vegetarianismo".

"Olha, é difícil o fato de você ter que estar sempre procurando, pesquisando, sabendo o que você pode levar para casa, sabendo o que você pode colocar no seu prato. Isso acaba sendo um pouco cansativo. [...] então você acaba tendo que despender mais tempo do seu dia para isso, você não pode simplesmente chegar e comprar, tem que fazer toda uma pesquisa”.

"Você ter que ficar sempre procurando onde você pode entrar, então, se você vai num casamento, o ideal é que você coma antes, ou então você leva alguma coisa porque provavelmente você vai ficar com fome. Então 
[...] todo vegano, para não passar por uma roubada tem que ser prevenido, se você vai viajar, tem que olhar antes, procurar por uns restaurantes que tenham opções, onde você pode comprar comida".

"Eu acho que essa coisa de pesquisar de antemão o que vou comprar, pesquisar as marcas, eu acho muito legal, porque a partir do momento que todo mundo fizer isso, as empresas começarão a mudar, a rastrear produtos, a se conscientizar das coisas porque há essa exigência. Eu fico feliz quando uma empresa para de testar em animais"

"Aqui no Nordeste a guerra da gente, a grande luta, vai ser levar o veganismo para quem está abaixo da classe média. Até hoje a medida de riqueza de um país está relacionada ao consumo de frango, carne. As pessoas torcem para você consumir mais. O fato de famílias pobres poderem comer carne é considerado uma vitória para o governo".

"A população tem o costume de consumir muitos produtos industrializados. Quando diminui a qualidade, diminui o preço. Então é uma mudança muito grande de hábitos. Para uma pessoa que come tudo com soro de leite que é barato, pensar em ser vegano causa essa dúvida sobre o que se vai comer. Isso reforça o mito de que ser vegano é caro".

"Essa questão de ser minoria ou não tem que levar em conta a marginalização. Tem nordestino passando fome e comendo uma vez por dia. Se você chega e fala para essa pessoa não comer carne, vai ser muito difícil ela aceitar. É incoerente para elas. Principalmente no sertão que não se tem acesso a nada. A dificuldade da gente vai ser trazer essas pessoas para o veganismo, tornar o veganismo acessível". 
Tabela 8. Dendograma da CHD do conteúdo do grupo focal ordenado por valor de $\chi^{2}$ ( $p$ $\leq 0,05)$.

\begin{tabular}{|c|c|c|c|c|c|c|c|}
\hline \multirow{2}{*}{\multicolumn{2}{|c|}{ Classe 4}} & & & & & & \\
\hline & & \multicolumn{2}{|c|}{ Classe 3} & \multicolumn{2}{|c|}{ Classe 2} & \multicolumn{2}{|c|}{ Classe 1} \\
\hline \multicolumn{2}{|c|}{$19,35 \%$} & \multicolumn{2}{|c|}{$39,25 \%$} & \multicolumn{2}{|c|}{$20,97 \%$} & \multicolumn{2}{|c|}{$20,43 \%$} \\
\hline Lema & $\chi^{2}$ & Lema & $\chi^{2}$ & Lema & $\chi^{2}$ & Lema & $\chi^{2}$ \\
\hline Comer & 40,01 & Ano & 18,1 & Ativismo & 42,5 & Vida & 27,1 \\
\hline Casamento & 21,41 & Tornar & 12,94 & Animal & 31,01 & Tentar & 19,13 \\
\hline Arroz & 17,03 & Vegetariano & 12,07 & Participar & 23,37 & Existir & 15,09 \\
\hline Alface & 17,03 & Bom & 11,42 & Informação & 23,26 & Vegan & 13,99 \\
\hline Respeitar & 17,03 & Tranquilo & 9,6 & Humano & 19,37 & Construir & 11,88 \\
\hline Difícil & 17,03 & Falar & 9,2 & Compaixão & 15,41 & Colocar & 11,64 \\
\hline Família & 16,73 & Magro & 7,95 & Origem & 15,41 & Acontecer & 11,34 \\
\hline Carne & 16,34 & Conhecer & 7,95 & Falta & 15,41 & Diferente & 11,22 \\
\hline Sentir & 16,26 & Preconceito & 7,95 & Explorar & 15,41 & Entender & 11,22 \\
\hline Sentar & 16,26 & Achar & 6,96 & Mostrar & 15,33 & Forma & 10,18 \\
\hline Chegar & 15,93 & Mudar & 6,88 & Consciência & 7,2 & Conseguir & 9,6 \\
\hline Planeta & 12,7 & Época & 6,59 & Objetivo & 6,83 & Mundo & 8,58 \\
\hline Pesquisa & 12,7 & Assunto & 6,59 & Pensar & 6,52 & Gente & 8,43 \\
\hline Cara & 9,97 & Avô & 6,33 & Empresa & 4,72 & Aprender & 7,49 \\
\hline Social & 8,11 & Pai & 6,33 & Legal & 3,84 & Filosofia & 7,49 \\
\hline Dia & 5,81 & Morrer & 6,33 & Movimento & 3,84 & Ativista & 7,49 \\
\hline Prato & 5,44 & Ouvir & 6,33 & Interessante & 3,84 & Situação & 6,03 \\
\hline Olhar & 4,37 & Momento & 6,33 & Despertar & 3,84 & Entrar & 4,95 \\
\hline Incomodar & 4,37 & Início & 6,33 & Consumo & 3,84 & Amor & 4,95 \\
\hline Fome & 4,37 & Afetivo & 6,33 & Ambiente & 3,84 & Dizer & 4,31 \\
\hline Escolher & 4,37 & Perguntar & 5,89 & & & Seguir & 4,01 \\
\hline Acabar & 4,09 & Começar & 5,09 & & & Grande & 4,01 \\
\hline Passar & 4,09 & Ver & 5,07 & & & Próprio & 4,01 \\
\hline & & Voltar & 4,72 & & & Enxergar & 4,01 \\
\hline & & Ruim & 4,72 & & & Conversa & 4,01 \\
\hline & & Irmão & 4,72 & & & Ação & 4,01 \\
\hline & & Faculdade & 4,72 & & & & \\
\hline Ver & $-5,08$ & Animal & $-7,56$ & Comer & $-12,16$ & Comer & $-8,95$ \\
\hline Achar & $-4,02$ & Ativismo & $-7,26$ & Carne & $-5,71$ & Carne & $-7,83$ \\
\hline Ativismo & $-3,92$ & Mostrar & $-6,83$ & Família & $-5,29$ & Ver & $-5,43$ \\
\hline & & Forma & $-6,83$ & Vegan & $-5,23$ & Família & $-5,12$ \\
\hline & & Gente & $-5,56$ & Dia & $-4,69$ & Começar & $-4,8$ \\
\hline & & Acontecer & $-5,14$ & Mundo & $-4,37$ & Achar & $-4,62$ \\
\hline & & Questão & $-4,46$ & & & & \\
\hline & & Vida & $-4,46$ & & & & \\
\hline & & Sentir & $-4,01$ & & & & \\
\hline & & Minoria & $-4,01$ & & & & \\
\hline & & Participar & $-4,01$ & & & & \\
\hline & & Informação & $-3,96$ & & & & \\
\hline & & Levar & $-3,96$ & & & & \\
\hline
\end{tabular}


A Figura 4 mostra a AFC destas classes. Pode-se observar que as classes 1 (vermelho) e 2 (verde) se acumulam na metade esquerda do plano. As formas ativas destacadas nessas classes reforçam os achados da análise de evocações, pois nelas são tratadas questões ligadas ao endogrupo, com seus valores de transcendência (vida, amor, compaixão, saudável). Em contraste, nos quadrantes opostos, as classes 3 e 4 tratam sobre os outros: o contato e diferenciação de nós vs. eles (preconceito, carne, família, difícil). Além disso, observa-se que há uma tensão entre essas classes, distanciando-as, uma vez que a classe 3 versa sobre o conflito e a angústia da transição, enquanto a classe 4 trata dos problemas práticos de inserção social.

\section{Coletivo}

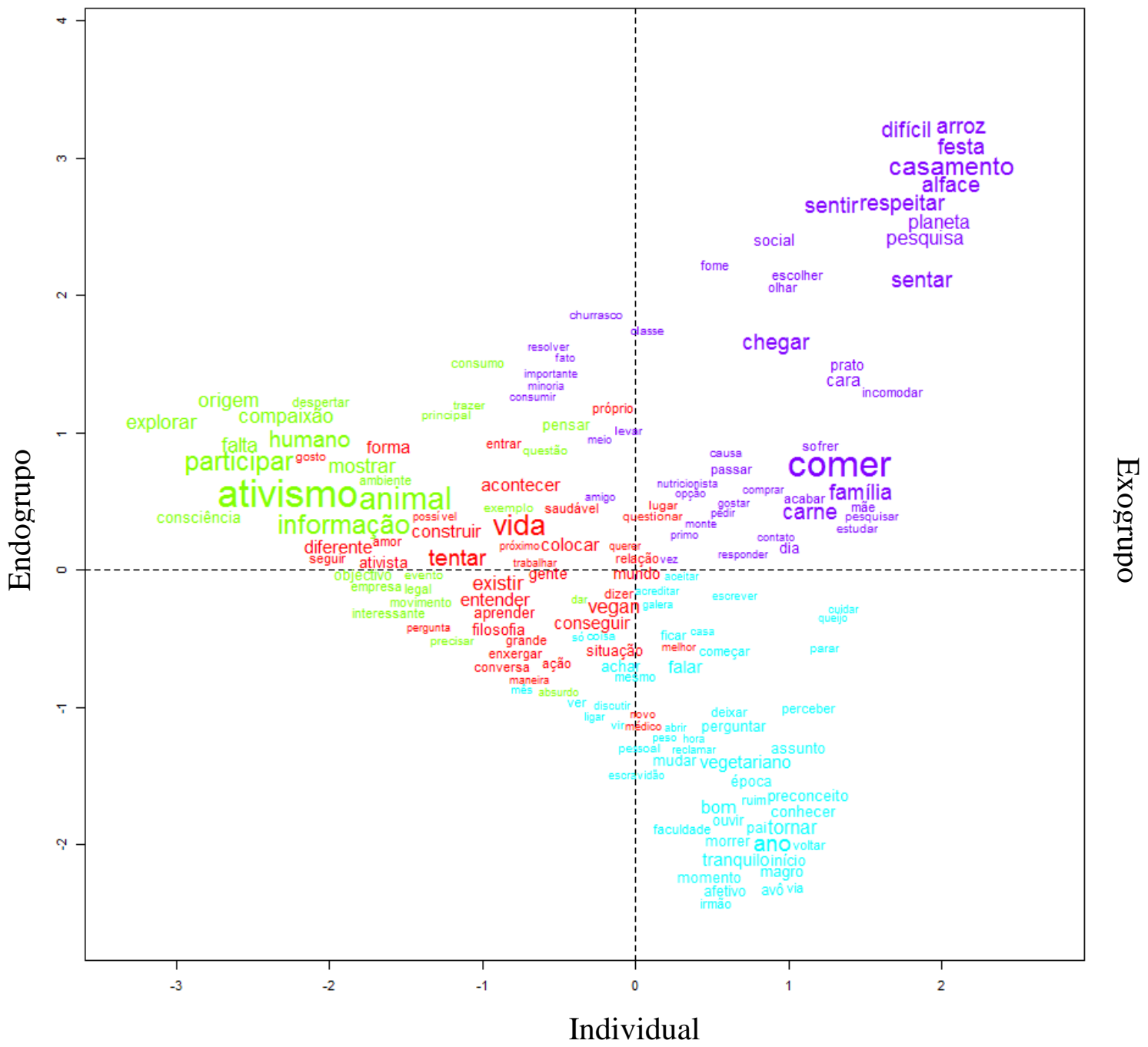

Figura 4. Análise fatorial de correspondência das formas ativas no discurso dos participantes do grupo focal. 


\section{Considerações Finais}

As representações sociais do veganismo pelos veganos, a partir da teoria do núcleo central, junto da análise dos dados demográficos e da análise do conteúdo do grupo focal corroboram os pressupostos do veganismo. De fato, os veganos se mostram preocupados com o meio ambiente, a saúde e preservação da vida, como conceituado em Santana et al. (2015) e observado no núcleo das representações. Porém, na prática, o consumo político ainda aparenta ser bastante restrito à alimentação. Esse fato pode estar relacionado com o quanto é recente o conhecimento sobre o aspecto não alimentar do consumo (uma vez que o caráter político do veganismo só veio à tona na academia nesta década), mas também pode refletir a falta de conhecimento sobre os métodos e práticas de produção da indústria "cruel”.

Há uma óbvia dissociação global entre o produto de origem animal e o animal em si (Kunst \& Hohle, 2016), conforme ilustrado também por Adams (2015) no conceito de "referente ausente", onde animais outrora vivos são transformados em "alimento" num processo pelo qual os próprios animais se tornam ausentes e seus corpos mortos são renomeados antes de serem comercializados ("vacas" se tornam "bifes", "porcos" se tornam "bacon”, etc.), o que dificulta a ação política dos ativistas, que lidam com a naturalização da violência praticada com animais que não existem de fato, por conta desse processo. Em uma cultura onde animais são tratados como bens de consumo e, mais frequentemente que qualquer outra coisa, como alimentos, uma ideologia que defende os direitos à vida, liberdade e não sofrimento, deve construir seu ativismo a partir do que é óbvio aos outros.

Como visto em Pazzini (2014), a cultura brasileira ainda padece de superar a visão "colonizadores versus colonizados" - onde o "outro" é invisibilizado e marginalizado em decorrência do que os distingue da maioria dominante - quando se 
trata de grupos e indivíduos que não se conformam. Assim, pode-se observar a partir dos dados oferecidos neste estudo, que a representação social do veganismo está sendo construída a partir de seus elementos de transcendência humana, para justificar posturas não hegemônicas de comportamento. 


\section{ARTIGO 2}

A ser traduzido para o inglês e submetido à revista Appetite 
"Não podemos construir uma sociedade baseada no veganismo" - Representações sociais do veganismo no Brasil.

"We cannot build a society based on veganism" - Social representations of veganism in Brazil.

\title{
Resumo
}

O presente estudo teve como objetivo acessar, descrever e analisar as representações sociais construídas pela população não vegana sobre o veganismo, a partir da óptica da teoria do núcleo central das representações sociais (Abric, 1976). Para isso, foram veiculados questionários de evocação de palavras online, os quais foram analisados pelo software Iramuteq para a produção da matriz representacional. Os resultados sugerem que a representação social dos não veganos sobre o veganismo é ancorada nas diferenças presentes nos hábitos alimentares dessas populações e que o contato dessas populações é permeado por atitudes preconceituosas não hostis. Na zona de transformação pode-se observar alguns elementos de avaliação positiva, indicando construção recente. Apesar disso, sugere-se que o veganismo ainda é compreendido mais como estilo de vida do que como um movimento social.

Palavras-chave: Representações sociais; veganismo; movimentos sociais; estilo de vida.

\begin{abstract}
This study aimed at accessing, describing and analyzing the social representations built by the non-vegan population about veganism using the central nucleus approach to social representations (Abric, 1976). To do so, word-evocation questionnaires where made available online, which were analyzed using Iramuteq to produce the representational matrix. Results suggest that the non-vegan social
\end{abstract}


representation is anchored on the food-habit differences between these groups, and that their social experience is permeated by non-hostile prejudiced attitudes. On the transformation zone, some positive-evaluation elements were observed, suggesting that this is a recent construct. Besides that, the results suggest that veganism is still understood more as a lifestyle than a social movement.

Keywords: Social representations; veganism; social movements; lifestyle.

\section{Introdução}

Atualmente, o movimento social vegano está crescendo e ganhando espaço tanto na mídia popular, quanto na academia. Em diversas sociedades dos países ocidentais desenvolvidos, veganos já correspondem a uma porção significativa dos adultos. No Brasil há, supostamente, 5 milhões de veganos - colocando o país em sexto lugar no mundo em porcentagem de veganos (2,5\% da população total) e primeiro lugar em números absolutos (Esteves \& Galinkin, 2017).

Apesar de ter sido convencionado em 1944 (Watson, 1965), o veganismo não foi adequadamente reconhecido pela academia até os primeiros anos do século XXI (Esteves \& Galinkin, 2017). Visto principalmente como uma dieta, o veganismo não tem sido tratado como movimento social. Estudos seminais que deram ao veganismo o status de "filosofia de vida e posicionamento ético e político" remontam a meados da década de 1970, com Libertação Animal (Singer, 1977), onde os meios cruéis pelos quais a indústria da pecuária produz seus bens foram denunciados. Desde então, pessoas se identificaram com a causa vegana e formaram grupos, tanto no nível de organizações, em ONGs como PeTA e ALF, em intersecções com outros movimentos sociais (p. ex. o ecofeminismo), quanto em grupos descentralizados de amigos e conhecidos que praticam o veganismo juntos social e diariamente. Acima de tudo, o veganismo 
começou a se estruturar como um movimento social fundado na abolição da exploração animal e, portanto, como um ato de desobediência civil que pretende subverter o status quo (Argolo, 2008).

Outros pesquisadores trabalharam em estudos sobre os aspectos éticos do veganismo desde então (Francione, 1996; Regan, 1988) e, mais recentemente, foram realizados esforços no sentido de trazer à tona o questionamento se todos os seres humanos deveriam ser veganos ou não, com base na dissonância cognitiva, tornando o veganismo assunto para estudos de psicologia social (Bratanova, Loughnan, \& Bastian, 2011; Cao \& Just, 2010; Joy, 2010; Piazza et al., 2015; Twine, 2014). Alguns desses estudos são direcionados a prover embasamento teórico ao ativismo vegano, questionando o comportamento daqueles que se alimentam de carne e consomem produtos derivados de animais, denominando-os "carnistas" (Joy, 2010).

O termo "carnista" se refere a um sistema de crenças que justificam o consumo de produtos animais fundamentado em mecanismos de defesa e suposições não questionáveis, ou seja, refere-se a um conjunto de atitudes em relação ao consumo que permitem a esses indivíduos a abstração do aspecto ético implícito na produção, por exemplo, da carne. Carnistas acreditam, por exemplo (mas não necessariamente), que o vegetarianismo é uma ideia de pouca utilidade e impacto, que o domínio humano sobre os animais acontece por determinação divina e que a abstinência da violência contra animais se tornaria uma ameaça à raça humana (Desaulniers, 2015), sendo que essa crença os permite continuar participando dos meios de produção tradicionais como consumidores. Estudos que investigaram a reação de pessoas à violência contra animais sugerem que o "paradoxo da carne” (Loughnan, Haslam, \& Bastian, 2010) - reação de desconforto ao pensar no sofrimento dos animais que faz com que as pessoas evitem pensar no assunto, ao invés de mudar seu comportamento - é uma das grandes razões 
para não veganos assumirem posturas defensivas, marginalizando socialmente a minoria não hegemônica do movimento vegano, além de banalizar a capacidade cognitiva e senciente dos animais (Bratanova et al., 2011; Cao \& Just, 2010). Entre os mecanismos utilizados para essa defesa, o mais conhecido e compartilhado talvez seja o dos "4 Ns" (Piazza et al., 2015). Nesse estudo, pessoas foram questionadas sobre seus motivos para comer carne e entre os mais citados estavam: 1. "Comer carne é Natural, a evolução nos selecionou como onívoros que precisam de carne para sobreviver"; 2. "Comer carne é Normal, todo mundo faz isso, então eu faço também”; 3. "Comer carne é Necessário, a carne é a melhor fonte de proteínas e, sem ela, nossa saúde fica prejudicada"; 4. O sabor é agradável [tastes $\mathrm{Nice}$ ], logo, não deve haver nada de mau nesse comportamento.

Curiosamente, homens e mulheres costumam reagir de formas distintas no momento de solucionar o desconforto causado pela dissonância cognitiva causada pelo contraste entre a prática cultural de consumir produtos animais e a consciência do modo de produção dos mesmos. Mulheres tendem à dissociação (ignoram a origem do produto), enquanto homens se apoiam na premissa cultural de que a carne é uma comida masculina (Rothgerber, 2013). Logo, o consumo da carne e dos produtos animais em geral é uma característica identitária masculina e, consequentemente, muito da discriminação praticada contra veganos se dá nesse âmbito. Diversas campanhas publicitárias são compostas de peças que exploram essa característica, com elementos muito pronunciados de machismo e misoginia (Adams, 2015).

A confrontação com as razões para não participar de um sistema que pratica exploração animal coloca os outros em situações nas quais devem se defender e justificar suas escolhas. No presente estudo, será utilizada a teoria das representações sociais (TRS), de Moscovici (Moscovici, 1961, 2003). A TRS parte de uma perspectiva que busca compreender o ser humano, considerando-o como sujeito construído a partir 
de suas determinações evolutivas, históricas, culturais e sociais e que também é agente de sua própria realidade social. As representações sociais caracterizam-se como um espaço de trocas que se retroalimenta, viabilizando, produzindo e transformando as próprias trocas. São definidas como um saber acerca do real que se estrutura na relação do sujeito com o objeto, mediada pelas interações com o outro. Ou seja, são construções e rearranjos cognitivos que permitem ao indivíduo explicar e compreender a realidade, justificando sua participação ou ausência em determinado contexto ou grupo. Dessa forma, representam um conjunto de saberes práticos criados a partir da interação com o outro (no sentido lato) que guiam a interpretação da realidade. Toda representação social é construída de forma que evite o conflito cognitivo. Portanto, a partir do contato com o outro, cada indivíduo absorve e transforma o conhecimento adquirido de forma a justificar e manter sua identidade individual ou grupal.

Para Moscovici, a assimilação desse conhecimento é sujeita a dois processos: objetivação e ancoragem. No primeiro, o conhecimento é transformado em imagens concretas por aproximação e reagrupamento de ideias e imagens que se enquadram no mesmo tema. Já no segundo, a imagem criada no primeiro processo é relacionada e comparada a conhecimentos prévios para que surja um conceito sobre o conhecimento que obedeça às necessidades do indivíduo para reforçar sua identidade individual ou grupal. Portanto, objetivação e ancoragem servem a função de tornar familiar o desconhecido e solucionar o conflito cognitivo do contato com o novo.

Dos desdobramentos realizados no decorrer dos anos, muito bem sintetizados por Sá (1998), o presente estudo faz uso da teoria do núcleo central (TNC), proposta por Abric (1976) para acessar, investigar a analisar as representações sociais deste grupo. A TNC propõe que as representações sociais possuem uma organização estrutural 
construída ao redor de um núcleo composto por elementos cognitivos mais estáveis, rígidos e consensuais e apresenta elementos individualizados, mutáveis e flexíveis em sua periferia. A teoria do núcleo central, portanto, postula que as representações se organizam ao redor de um núcleo central normativo, bastante rígido e perene representativo das condições históricas do grupo, construído em função do sistema de normas em que se está inserido - e de sistemas periféricos funcionais, resultantes da experiência individual e que permitem que as representações sejam flexíveis e adaptáveis. É nos sistemas periféricos que se encontram os elementos de manutenção do núcleo central, ou seja, qualquer novo elemento que possa interferir na representação é avaliado e adaptado a partir dos sistemas periféricos, de forma a evitar que o núcleo central seja colocado em xeque.

A abordagem Estrutural (Abric, 1976), busca identificar a estrutura das representações sociais a partir da análise da evocação de palavras e de sua categorização. Esta análise viabiliza o reconhecimento dos elementos formadores, centrais e periféricos, das representações sociais. Com isso, é possível verificar a existência de um processo de transformação das representações sociais (FonteneleMourão, 2006). Considerando que este é um movimento de emergência recente no Brasil, os sistemas periféricos das representações dos participantes devem revelar quais os temas e valores que estão sendo utilizados por eles para justificar sua escolha pelo não veganismo, quais crenças estão sendo negociadas em sua experiência social com veganos e quais são os argumentos centrais e primordiais para essa justificativa.

Concluindo, a partir do pressuposto de que as representações sociais são construídas obedecendo a demanda de não criar dissonâncias cognitivas e, portanto, reforçam a identidade de quem as compartilha, buscou-se identificar valores e crenças 
reforçadores do carnismo no núcleo central. Este núcleo estaria cercado por outros valores e crenças que refletem a forma como se dão as relações sociais destes indivíduos com veganos, bem como indícios de como se estruturam suas atitudes preconceituosas.

Numa perspectiva histórica, as diferenças pessoais podem servir o propósito de criar diversidade sociocultural. Entretanto, alguns indivíduos acabam por militar a favor de suas posições discordantes numa tentativa de influenciar a maioria, gerando

conflitos. É sabido que os ideais de minorias, quando bem embasados, instigam o backlash (reação de aversão intensa ao novo), como a História demonstra nos casos de grandes saltos da Ciência (heliocentrismo, esfericidade da terra, evolução das espécies, entre outros), ou mudanças da norma social (abolição do regime escravocrata, sufrágio feminino, fim do Apartheid, entre outros). Seja ou não esse pertencimento à minoria um ato deliberado (em oposição ao pertencimento vinculativo como o de raça, gênero, ou orientação sexual), o ativismo enfrenta barreiras impostas pela maioria hegemônica. De acordo com o pensamento de Moscovici (1996), a inovação é um processo essencial da existência da sociedade, ao invés de uma forma de desvio. Ou seja, a atuação das minorias ativas teria papel central na manutenção da inclusão de todos os indivíduos componentes da sociedade no corpo social.

\section{Objetivos}

\section{Principal}

Acessar, descrever e analisar as representações sociais construídas pela população não vegana sobre o veganismo, a partir da óptica da teoria do núcleo central das representações sociais.

\section{Secundários}

Discutir a inserção social dos veganos, a forma como seu ativismo atinge a população não vegana e quais os prováveis impedimentos presentes na cultura 
brasileira que promovem essa marginalização.

\section{Métodos}

\section{Participantes}

Ao todo, 79 participantes foram responderam completamente à pesquisa via online. O link para o questionário foi veiculado pelas redes sociais e por e-mail para todos os Estados do país, de forma a compor uma amostra nacional. Os participantes que não completaram o questionário foram removidos da amostra. Todos os participantes consentiram livre e esclarecidamente com a participação (Anexo 1)

\section{Instrumentos}

Questionários. Foi elaborado um questionário composto por duas partes: questionário sociodemográfico e questionário de evocação de palavras (Anexo 2).

As questões visavam acessar o perfil sociodemográfico dos participantes de modo a caracterizar a amostra em termos de sua representatividade. Dados estatísticos do único portal brasileiro que pratica o censo populacional de vegetarianos e veganos indicam haver cerca de 5 milhões de veganos no Brasil, representando 28,5\% do total de vegetarianos (Mapa Veg, n.d.), que já somam 8\% da população nacional (IBOPE, 2012). Revela ainda haver maior concentração desses grupos na região sudeste do Brasil. Dados como sexo, faixa etária ou tempo de prática da ideologia vegana estão indisponíveis em outras fontes. Assim, a população não vegana do Brasil é de cerca de 195 milhões de pessoas. Por fim, havia uma questão destinada a acessar a representação dos participantes sobre eles mesmos, onde deveriam se categorizar em "onívoros", “carnívoros", "vegetarianos", "crudívoros", ou “outros".

O questionário de evocação de palavras que, por sua vez, representa o instrumento de acesso às representações sociais em si, consistia de um termo indutor 
("veganismo") e pedia para que o participante listasse as 5 primeiras palavras ou ideias que surgissem em suas mentes relacionadas a esse termo. Em seguida, solicitou-se que escolhessem e justificassem, dentre as evocações listadas, a que fosse mais representativa do significado do termo indutor em suas opiniões.

\section{Procedimentos}

Questionários. O acesso aos dados provenientes da população se deu de forma online na plataforma Survey Monkey e, subsequentemente, sua divulgação foi feita a partir do envio do link de acesso por email, postagens em grupos de redes sociais e pela estratégia da "bola de neve" em diversos meios.

Análise de dados. A análise dos dados demográficos foi realizada no software Microsoft Excel 2016. Os dados do questionário de evocação foram analisados pelo software Iramuteq (Interface de R pour les Analyses Multidimensionnelles de Textes et de Questionnaires), um software gratuito e com fonte aberta que permite fazer análises semânticas sobre corpus textuais e sobre tabelas de indivíduos/palavras. Todas as respostas foram transcritas para os processadores de dados do pacote Libre Office. Para que fossem processados separadamente, cada participante recebeu um código numerado $\left(* * * * * \mathrm{R} \_\mathrm{n}^{\mathrm{o}}\right.$ do participante) na codificação textual.

As cinco palavras evocadas por cada sujeito foram organizadas em uma tabela e submetidas à análise de matrizes pelo software Iramuteq, que organiza as evocações por frequência e ordem de evocação, de acordo com a teoria do núcleo central (Abric, 1976). Evocações mais frequentes e localizadas entre as primeiras evocações serão alocadas no quadrante representativo do núcleo central, enquanto as menos frequentemente evocadas, e/ou evocadas por último, formarão os sistemas periféricos da representação social. O cálculo final é realizado pela média ponderada entre os fatores 
"frequência" e "ordem de evocação". Na matriz, o primeiro quadrante (superior, à esquerda) representa o núcleo central da representação, onde residem os valores mais rígidos e perenes; a primeira periferia (superior, à direita) confere proteção ao núcleo, sendo mais flexível e adaptável às experiências e contextos nos quais os indivíduos participam. Os elementos contrastantes (inferior, à esquerda) são variações da representação características de seus subgrupos, mas que reforçam o núcleo central, ou seja, representam pontos de vista diferentes e transições entre representações. Por fim, a segunda periferia (inferior, à direita), também representa uma região de troca, de valores que estão sendo negociados pelos indivíduos em sua experiência social.

As falas que justificam a escolha de uma das evocações como mais relevante foram analisadas pelo mesmo software, porém submetidas a uma classificação hierárquica descendente (CHD) simples. Essa análise gera classes de segmentos de texto (ST) que apresentam os contextos em que termos foram evocados com proximidade entre si com frequência relevante e isolados o suficiente para serem diferentes dos ST das outras classes (Camargo \& Justo, 2013). A análise lexical, além de evidenciar tipos diferentes de discursos utilizados pelos participantes da pesquisa, permite - pelo uso das UCEs que se categorize o conteúdo da fala (A. R. A. do Nascimento \& Menandro, 2006), de forma equivalente à análise de conteúdo de Bardin (1977).

Em maior profundidade, a análise realizada pelo software Iramuteq para corpos de texto (corpus) utilizando o método da CHD realiza alguns cálculos sobre a coocorrência de palavras em ST, buscando distinguir classes de palavras que representem as diferentes abordagens do discurso sobre o tópico investigado. "As classes geradas a partir da CHD representam o contexto de sentido das palavras e podem apontar representações sociais ou elementos de representações sociais sobre o objeto social estudado" (Castro, Papaleo Koelzer, Vizeu Camargo, \& Barbará S. Bousfield, 2014, p.209). O pressuposto é que 
pontos de vista diferentes produzem diferentes discursos e o uso de um vocabulário específico sobre um objeto se torna um meio para identificar maneiras diferentes de pensá-lo. O objetivo da análise pela CHD, portanto, "é distinguir classes de palavras que representam diferentes formas de discurso a respeito do tópico de interesse" (Kronberger \& Wagner, 2002, p.427).

O processo analítico consiste de algumas etapas: (1) leitura e produção do dicionário, onde o programa estabelece a Unidade de Contexto Inicial (UCI), que corresponde ao corpus inteiro a ser fragmentado. Nesse momento é gerado o dicionário da análise, que deve ser revisado e editado de forma a verificar se a lematização - estabelecimento de uma unidade radical para cada termo, que o une a seus semelhantes -, bem como se a classificação gramatical está adequada. A seguir, (2) a UCI é fragmentada em Unidades de Contexto Elementar (UCE), definida segundo critérios estabelecidos pelo pesquisador de tamanho do ST e pontuação. "É a partir do pertencimento das palavras de um texto a uma UCE, que o programa vai estabelecer as matrizes a partir das quais será efetuado o trabalho de classificação" (Reinert, 1998, p. 17). Nessa etapa, a análise consiste na busca pela associação frequente entre termos, de forma a isolá-los em classes. É de responsabilidade do pesquisador encontrar o número de classes ideal para seu corpus, de modo que ao menos $75 \%$ dele seja utilizado na produção das classes, bem como que seja possível identificar categorias de conteúdo que não se sobreponham. Os termos constituintes de cada classe são classificados de acordo com o Chi-quadrado $\left(\chi^{2}\right)$ de associação dos radicais às suas respectivas classes, permitindo que elas sejam categorizadas de acordo com as UCE que a compõem. Nesta etapa, é indicado selecionar quais as classes gramaticais a serem consideradas como ativas no discurso, de forma a limpar os dados. "A lógica é trabalhar com os elementos de linguagem 'plenos' como ativos: adjetivos, formas não reconhecidas, nomes (substantivos), verbos; 
e com nomes (substantivos) e verbos auxiliares como complementares (suplementares); eliminando as 'palavras instrumento"” (Camargo \& Justo, 2013). Especificamente no presente estudo, como houve edição ao dicionário, todas as formas não reconhecidas foram devidamente designadas a suas classes gramaticais correspondentes, bem como a lematização foi adequada.

Entre os outputs gerados pela análise, destacam-se a Análise Fatorial de Correspondências (AFC) e o dendograma. A AFC consiste na representação gráfica cartesiana da proximidade - ou oposição - entre classes. Nesta análise é possível, portanto, inferir quais tipos de discursos representam pontos de vista semelhantes ou não, bem como suas relações de tensão ou coerência, a partir de sua localização no plano. O dendograma, por sua vez, é um diagrama de árvore representativo das classes e denota a estrutura de derivação entre elas - que corresponde ao valor de $\chi^{2}$ representativo dessa relação (com relação $=0$ na origem $)$-. Além disso, evidencia, em porcentagem, a parcela do corpus que cada classe representa e traz as palavras mais representativas (de maior $\chi^{2}$ ) dentre as UCEs de cada uma.

\section{Resultados e discussão}

\section{Dados demográficos}

Ao todo, 79 participantes de 13 Estados, além do Distrito Federal, responderam ao questionário, dos quais 63,29\% são do sexo feminino; 2,53\% (menores de 18 anos), $21,52 \%$ (entre 19 e 23 anos), 24,05\% (entre 24 e 28 anos) e 51,89\% (nas faixas de 29 a 33 e acima de 34); 51,9\% com Ensino Superior completo ou em curso; 86,08\% possuem renda própria; e 65\% se considera "carnívoro".

Segundo a Pesquisa Nacional por Amostra de Domicílios (PNAD) de 2014, a população brasileira é composta por 51,6\% de mulheres (Instituto Brasileiro de Geografia e Estatística - IBGE, 2015b). A predominância de mulheres participando no 
presente estudo, para além do esperado estatisticamente, pode ser explicada pelo próprio viés que uma pesquisa sobre uma ideologia predominantemente associada à alimentação gera. Historicamente, além de estarem associadas a comportamentos mais compassivos e empáticos, mulheres são mais associadas à lida com o alimento, desde a escolha do que deve ser trazido ao lar, até a tarefa de cozinhar as refeições. Para os homens, o contato com o alimento (seja ele advindo da caça, ou não) se deu historicamente como demonstração de dominância, masculinidade predatória e reafirmação de poder social (Adams, 2015; Adamson, 2004; Berndsen \& Pligt, 2004; Carlin \& Rosenthal, 1998; Gelfer, 2013; Rothgerber, 2013; Sobal, 2005; Tobin, 1999; Torres \& Allen, 2006). Diversas das tentativas de abordagem em grupos de redes sociais com o tema "churrasco", ou "carne", por exemplo, foram recebidas, ao notarem que era uma pesquisa sobre veganismo, com hostilidade contra o pesquisador, respondendo à solicitação de participação com imagens e frases questionando a masculinidade dos veganos (Anexo 3), sugerindo que o simples fato de ser questionado sobre o tema do veganismo já se configura como uma afronta aos indivíduos abordados, diversas vezes direcionada à sua masculinidade.

Outro dado interessante é a predominância de respondentes com altos níveis de instrução. No Brasil, apesar de crescente, a porcentagem das pessoas com acesso à internet que possuem baixos níveis de instrução ainda é reduzida - enquanto aproximadamente $90 \%$ dos brasileiros com pelo menos 15 anos de estudo usa a internet, entre aqueles que estudaram por metade desse tempo, apenas $34,5 \%$ tem acesso à rede (Instituto Brasileiro de Geografia e Estatística - IBGE, 2015a). Assim, supõe-se que pesquisas veiculadas pela internet com o público geral possuam esse viés.

Por fim, o fato de $65 \%$ dos respondentes se considerarem "carnívoros", em detrimento do conceito correto de onivorismo - levando em conta o grau de 
escolaridade dos respondentes -, sugere que a confrontação com uma pesquisa sobre veganismo reforça a identidade a partir dos meios pelos quais cada indivíduo se alimenta. Por definição, carnivorismo é o nome dado à prática alimentar de animais que se alimentam predominante ou exclusivamente de carne (de caça, ou carniça) e que, nos mamíferos, apresentam presas, molares cortantes e garras. Ou seja, responder essa opção pode estar refletindo o mecanismo de defesa da dissonância cognitiva agindo sobre o desconforto causado pela reflexão gerada pelo tema "veganismo". Os 4 Ns de Piazza (2015) vêm à tona e fazem com que o onivorismo seja exagerado para carnivorismo, assim como, em geral, afrontas à identidade provocam respostas de autoafirmação (Branscombe, Ellemers, Spears, \& Doosje, 1999).

\section{Questionário de evocação de palavras}

O resultado da análise de evocação (Tabela 9) revela, em seu núcleo central, as seguintes palavras que, provavelmente, constituem a porção mais rígida e normativa da representação social do que é veganismo. É possível reconhecer nestas evocações três categorias de termos, relacionados à alimentação - vegetais, natural, vegetariano e fome -, à saúde - saúde e saudável - e à ética - ideologia e animais. Sugere-se que há, portanto, a ideia de que os não veganos compreendem o veganismo como uma prática alimentar focada na preservação dos animais e da natureza. Esse posicionamento está presente nas falas que justificam as evocações: “Acredito que pessoas veganas são mais saudáveis que pessoas que comem carne" (Participante $\left.\mathrm{n}^{\circ} 56\right)$; "Acho que as pessoas adeptas a esse tipo de dieta, valorizam a alimentação natural, livre de ingredientes animais" (Participante $\mathrm{n}^{\circ}$ 75); "Saudável, visto que não se come carne e tenta-se ter uma alimentação mais equilibrada e saudável" (Participante $\left.\mathrm{n}^{\circ} 45\right)$. 
A primeira periferia e os elementos contrastantes formam o sistema periférico da representação, sendo esta a parte mais flexível e dependente de contextos e experiências. Assim, nesse sistema periférico é possível observar e acessar processos de mudança nas representações sociais. Na primeira periferia com termos de maior importância e frequência - constam os termos: difícil, soja, estilo de vida, verde, sustentabilidade, natureza, salada, radical, legumes e respeito. Já nos elementos contrastantes da periferia - com menor frequência e importância - constam: dieta, verduras, proteção aos animais, não come/comer carne, verdura, comida, extremo, dificuldade, restrição, orgânico, folhas, frutas e vegetarianismo.

Novamente, é possível categorizar os termos em relacionados à alimentação verde, salada, legumes, dieta, verduras, não come / comer carne, verdura, comida, orgânico, folhas, frutas e vegetarianismo - e à ética - estilo de vida, sustentabilidade, natureza, respeito e proteção aos animais. Mas também surgem conotações negativas difícil, radical, soja, extremo, dificuldade e restrição. Nota-se que alguns dos elementos se assemelham muito aos do núcleo central, porém, esse tipo de fenômeno é esperado, uma vez que o núcleo central e as periferias formam o sistema da representação social. Ou seja, os sistemas se complementam para formarem, juntos, a representação social de fato (Sá, Vetere, Castro, Oliveira, \& Carvalho, 2009, conforme citado em Barros, 2015). O que esses dados sugerem é que o viés já comentado de que a representação social predominante sobre o veganismo na sociedade brasileira é que ele se restringe a uma dieta saudável, que seus praticantes se preocupam com a natureza e a sustentabilidade, mas que é uma realidade distante baseada em comportamentos extremistas de mudanças de comportamento desimportantes: “É uma ideologia que restringe bastante os hábitos alimentares" (Participante $\left.\mathrm{n}^{\circ} 04\right)$; “Inútil, não podemos construir uma sociedade 
baseada no veganismo" (Participante $\mathrm{n}^{\mathrm{o}} 20$ ); "Extremista, porque os veganos evitam até alimentos que seu consumo não acarretam na morte do animal, tal como laticínios e mel"' (Participante n⿳061).

Por fim, a segunda periferia, a mais distante do núcleo central "representa as mudanças recentes na estrutura e hierarquia das representações sociais" (Barros, 2015, p. 76). Nesta região encontram-se as palavras evocadas por último e com menor importância: vida, consciência, radicalismo, carne, chato, sabor, alimentação, naturalista, utopia, futuro, limitação, tofu, militância, compaixão, sem carne, amor e meio ambiente. Novamente, categorizados entre aqueles relacionados à alimentação carne, sabor, alimentação, sem carne -, à ética - vida, consciência, naturalista, futuro, militância, compaixão, amor e meio ambiente - e conotações negativas - radicalismo, chato, utopia, limitação e tofu.

Esta zona de transformação corrobora achados como o de Joy (2010), Rothgerber(2013), Desaulniers (2015), e Piazza et. al. (2015), onde não veganos (ou carnistas) se apoiam em crenças que distanciam a crítica tanto aos meios de produção, quanto ao proposto pelo veganismo para justificar e manter seus comportamentos afastados da dissonância cognitiva. Esse tipo de crença serve de fundamento para comportamentos de backlash, como em: "Acho que a valorização da vida é muito bonita, mas acho, honestamente, que este embasamento para o veganismo me parece um pouco seletivo. [...] tem a questão da criação de insetos para consumo, que tem surgido como alternativa para suplantar a necessidade alimentícia da população mundial [...] ao que me parece é uma alternativa bastante viável, talvez até mais viável em termo de custo/recursos/caloria, a resposta que recebo são olhares estranhos e a negação da possibilidade. Apesar de concordar que o consumo absurdo das carnes que temos hoje é insustentável, não consigo deixar de ver seletividade no argumento 
vegano" (Participante n45); “Meus amigos veganos querem me converter e não respeitam minha posição" (Participante n¹9); "Extremo, pois a maioria dos veganos que conheço parecem estar sempre tentando convencer os outros a viverem o estilo de vida deles" (Participante $\left.\mathrm{n}^{\circ} 73\right)$.

A presença de termos com conotação negativa, associados aos relativos à alimentação, nesses quadrantes periféricos denota que a experiência social dos não veganos, quando em contato com o veganismo, continua sendo principalmente por meio das diferenças nos hábitos alimentares praticados por eles. Poucos são os termos que trazem o conteúdo político e ético do ativismo vegano ("amor", "consciência", "militância", "compaixão") e sua presença na segunda periferia das representações sugere que esta população vem sendo exposta a esse aspecto ativista mais recentemente, refletindo o quanto é recente até mesmo para a população vegana no Brasil que se compartilhe esse tipo de conhecimento.

Outro estudo sobre representações sociais do veganismo sugeriu que o ativismo vegano começou recentemente a praticar o aspecto político, inclusive entre os próprios veganos (Esteves \& Galinkin, 2017). De certa forma, não surpreende, então, que a representação social compartilhada pelos não veganos seja ancorada dessa maneira. Ademais, a presença de termos discriminatórios nos quadrantes de elementos contrastantes e segunda periferia sugere que as atitudes preconceituosas se expressam no contato social com o veganismo. 
Tabela 9. Matriz de coocorrências dos termos evocados pelos participantes (EvocaçãoFrequência-Ranking médio).

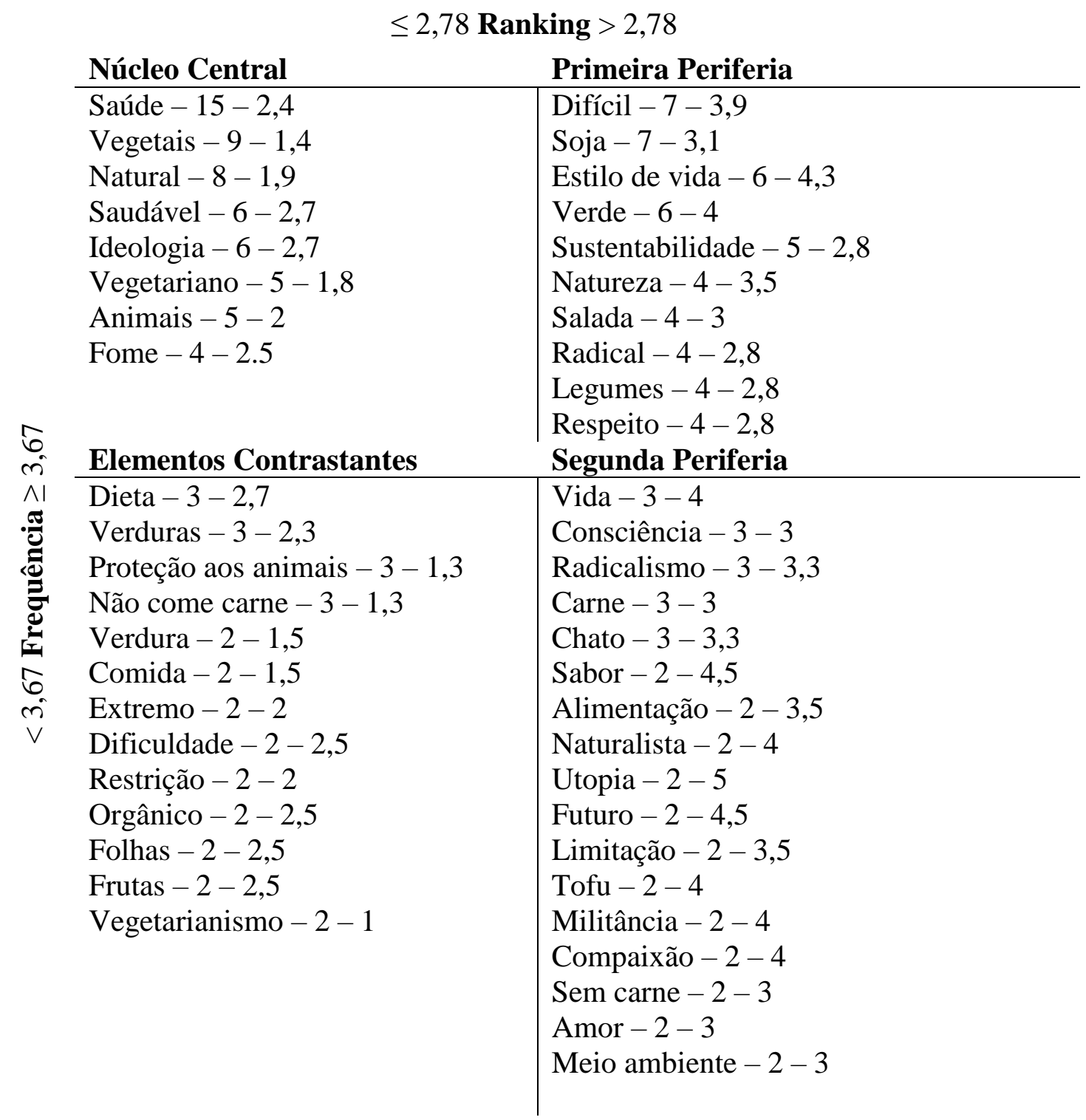

A CHD realizada com as falas proferidas para justificar a escolha da evocação mais pertinente gerou 3 classes (Tabela 10). Dos 78 ST, 69 puderam ser analisados $(88,46 \%)$. A primeira classe, representando $20,29 \%$ de todos os ST, ao agrupar os termos “carne", "saudável”, "vegetal", "alimentação", entre outros, reflete o tema que foi central na análise da representação social pela teoria do núcleo central. Pouco menos de um terço do discurso de justificação das evocações foi destinado e tratar desse aspecto dietético do veganismo: 
"Acredito que pessoas veganas são mais saudáveis que pessoas que comem carne" (Participante $\left.\mathrm{n}^{\circ} 56\right)$

"Acho que as pessoas adeptas a esse tipo de dieta, valorizam a alimentação natural, livre de ingredientes animais" (Participante $\left.\mathrm{n}^{\circ} 75\right)$

"Saudável, visto que não se come carne e tenta-se ter uma alimentação mais equilibrada e saudável" (Participante $\left.\mathrm{n}^{\circ} 45\right)$

Apesar de pouco citado, cabe notar que o discurso sobre o veganismo ser saudável vem carregado de comparações, do tipo "eles são mais saudáveis do que eu”. Essa comparação é uma das formas de ameaça à identidade citadas por Branscombe et al. (1999) conhecida como "ameaça de categorização", onde a categoria em que colocamos outro grupo é prejudicial à nossa autoestima. Assim, por mais lisonjeira que possa parecer a avaliação, ela não necessariamente é positiva.

A segunda classe, com $44,93 \%$ dos ST, traz as justificativas nas quais os respondentes conceituam o veganismo como uma causa pelos animais através dos termos "animal", "respeito", "proteção" e "consumir", por exemplo. Sendo, esta, a classe com maior representatividade na análise, sugere que o valor vegano de defesa da abolição da exploração animal é razoavelmente bem compreendido pelos não veganos.

"A maior parte de pessoas veganas que conheço, optaram por tal dieta por não quererem compactuar com os maus tratos que sofrem $\mathrm{em}$ criadouros. Tanto que em eventos veganos, há diversas palestras de conscientização sobre como a indústria maltrata animais para sustentar o nosso consumo" (Participante $\left.\mathrm{n}^{\mathrm{o}} 66\right)$ 
“O vegano não consome nada de origem animal. Acredito que eles veem que não é necessário matar um ser vivo para conseguir viver e se alimentar" (Participante $\mathrm{n}^{\mathrm{o}}$ 07)

"Vejo o veganismo como uma ideologia que pretende levantar questões sobre o sofrimento dos outros animais, envolvidos no modo de produção de bens de consumo" (Participante $\mathrm{n}^{\circ} 48$ )

A aparente disparidade entre o achado da CHD com a investigação da representação social por evocação tem fundamento na própria teoria do núcleo central (Abric, 1976), onde ao ser solicitado que explique algo em cinco palavras, o participante responde por último os valores fundadores da atitude preconceituosa. Ou seja, pela média ponderada, os preconceitos se acumulam nos dois últimos quadrantes. Assim, é esperado que grande parte dos discursos de justificativa sejam formados a partir das primeiras e mais positivas evocações.

A terceira classe, por fim, representa $34,78 \%$ dos ST analisados. Nela, o discurso se divide entre considerar o veganismo como uma ideologia, ou um estilo de vida, com termos como "ideologia", "escolha", "postura" e "vida". "Para ser vegano deve-se apegar mais a ideologia das razões do que a outros aspectos como praticidade e convenção social" (Participante $\left.\mathrm{n}^{\circ} 45\right)$ "Ideologia, pois trata-se de uma forma de ver o mundo, seja no sentido biológico próprio do ser humano, seja nas relações do ser com o ambiente e com seu contexto social, cultural e histórico" (Participante $\mathrm{n}^{\circ} 32$ ) 
"Estilo de vida, afinal, é uma mudança radical não só na alimentação, mas em toda a forma de reconhecer o que é saúde e se reconhecer" (Participante $\mathrm{n}^{\mathrm{o}} 53$ )

“O veganismo é uma escolha, guiada por ideologias ou princípios, que vai levar a consequências e uma forma de estar no mundo" (Participante $\mathrm{n}^{\mathrm{o}}$ 52)

Tabela 10. Dendograma da CHD realizado com as justificativas dadas às evocações selecionadas pelos participantes ordenado por valor de $\chi^{2}(p \leq 0,05)$.

\begin{tabular}{|c|c|c|c|c|c|}
\hline \multicolumn{2}{|c|}{$\begin{array}{c}\text { Classe } 3 \\
44,9 \%\end{array}$} & \multicolumn{2}{|c|}{$\begin{array}{c}\text { Classe } 1 \\
20,3 \%\end{array}$} & \multicolumn{2}{|c|}{$\begin{array}{c}\text { Classe } 2 \\
34,8 \%\end{array}$} \\
\hline Lema & $\chi^{2}$ & Lema & $\chi^{2}$ & Lema & $\chi^{2}$ \\
\hline Ideologia & 12,76 & Carne & 30,6 & Animal & 26,96 \\
\hline Vida & 10,4 & Saudável & 16,68 & Origem & 11,09 \\
\hline Escolha & 7,96 & Vegetal & 11,88 & Vegan & 6,81 \\
\hline Só & 5,88 & Acreditar & 7,96 & Respeito & 5,2 \\
\hline Relação & 5,88 & Alimentação & 5,12 & Proteção & 5,2 \\
\hline Postura & 5,88 & Produção & 4,17 & Consumir & 4,51 \\
\hline Palavra & 5,88 & Escolher & 4,17 & Respeitar & 3,84 \\
\hline Mundo & 5,88 & Comer & 3,59 & Conhecer & 3,84 \\
\hline Forma & 4,86 & Achar & 2,45 & & \\
\hline \multirow[t]{2}{*}{ Estilo } & 4,64 & Parecer & 2,32 & & \\
\hline & & Melhor & 2,32 & & \\
\hline Animal & $-15,21$ & Ideologia & $-3,33$ & Vida & $-6,66$ \\
\hline Consumir & $-5,52$ & Animal & $-3,25$ & Carne & $-6,36$ \\
\hline Acreditar & $-5,52$ & Origem & $-2,3$ & & \\
\hline Origem & $-4,83$ & & & & \\
\hline Carne & $-4,15$ & & & & \\
\hline Vegan & $-3,85$ & & & & \\
\hline
\end{tabular}

A discussão sobre o veganismo ser um estilo de vida ou um movimento social já existe, apesar de não haver consenso (Véron, 2016). Há uma tendência ao desuso da figura do "militante dedicado à mudança revolucionária e distante da mundanidade da vida cotidiana" (Chatterton \& Pickerill, 2010) e, na 
consequente intersecção entre o movimento social pelos direitos animais e o estilo de vida vegetariano, o ativismo vegano deve ser interpretado como um conjunto de práticas comportamentais fundamentadas na comunalidade entre movimento social e estilo de vida (Esteves \& Galinkin, 2017).

A Figura 5 representa a AFC das classes, onde pode-se observar as três classes em tensão mútua. Os três discursos principais, "dieta sem carne", "defesa dos animais" e "ideologia/estilo de vida", são representados como bastante distintos, o que sugere que os veganos estão conseguindo passar a ideia de ser um movimento social, porém fundado em elementos funcionais (comportamentais), ao invés de normativos - como seria esperado de um grupo considerado praticante de uma ideologia política e ética.

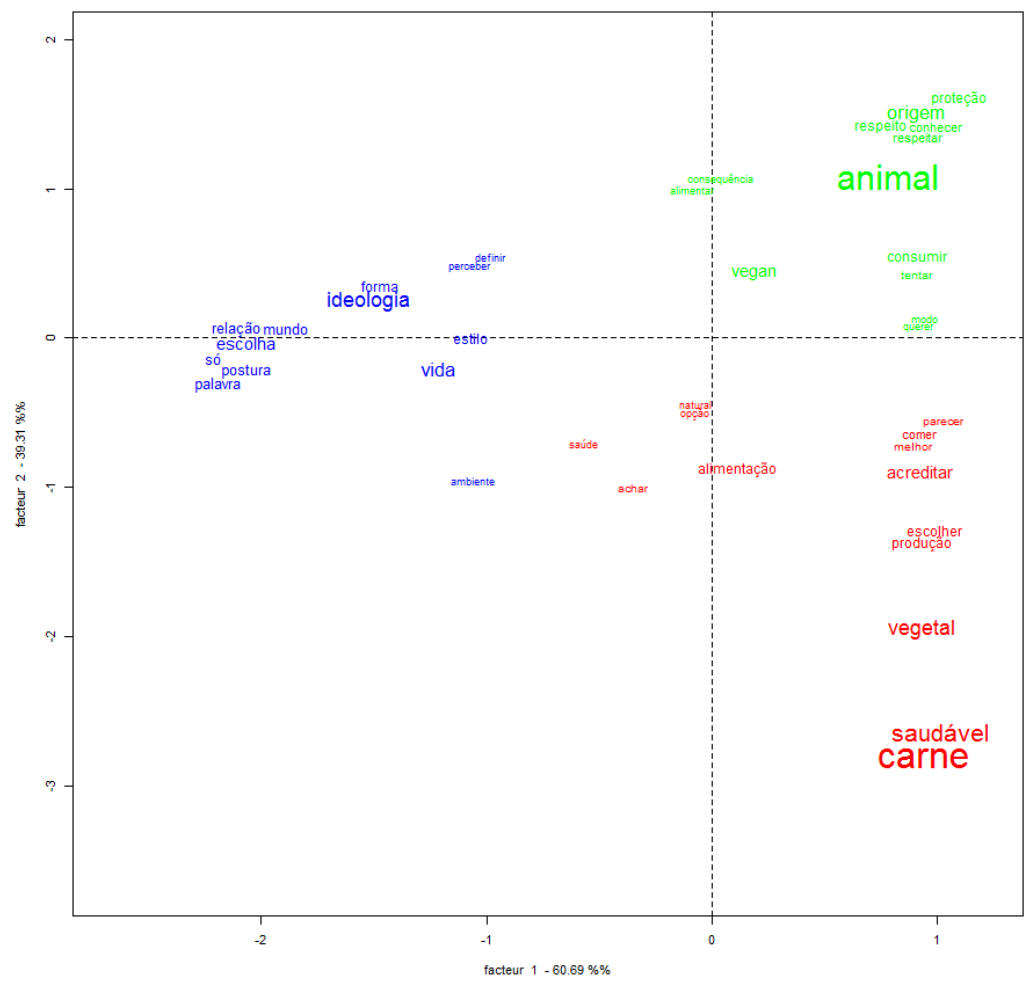

Figura 5. Análise fatorial de correspondência das formas ativas no discurso de justificação da escolha do termo mais relevante no questionário de associação de palavras. 


\section{Considerações Finais}

Pesquisas sobre preconceito e discriminação frequentemente encontram disparidades em seus resultados frente ao que é observado empiricamente, devido ao fenômeno da desejabilidade social - onde o participante mascara seu preconceito para não ser mal avaliado pelos outros, ou, no caso, pelo pesquisador. Assim, é de se esperar que os respondentes não escolham os termos mais carregados de preconceito como mais relevantes. O material coletado durante e após a abordagem aos participantes (Anexo 3) é crucial para reafirmar o posicionamento adotado neste estudo. Longe do âmbito da pesquisa científica, a experiência social dos veganos é permeada por esse tipo de discurso androcêntrico. Uma forma de contornar esse tipo de fenômeno é a investigação da zona muda das representações sociais (Abric, 2005), onde os participantes respondem por si e pelo que acreditam que seria a postura de outros. Estudos futuros podem investigar esse aspecto das representações sociais de não veganos, também com amostras maiores, de forma a dar mais luz à questão da marginalização desse grupo.

De fato, estudos demonstram que o consumo de carne e produtos animais está ligado a ideais de dominância social (Berndsen \& Pligt, 2004), valores verticais (Torres \& Allen, 2006) e masculinidade (Adams, 2015). A sociedade brasileira ainda é bastante conservadora e machista, o poder aquisitivo das famílias ainda é medido a partir da sua capacidade de comprar e consumir a carne (Martins et al., 2011) e a cultura do churrasco é predominante em diversos estados das regiões Sul e Sudeste. Assim, o veganismo ainda leva consigo o prognóstico de enfrentar os valores mais radicais da cultura do país que é o maior exportador de carne bovina do mundo (Confederação da Agricultura e Pecuária do Brasil, 2016) antes de ser considerado mais do que uma dieta restritiva e extremista. 


\section{CONCLUSÃO}

Os resultados que antecedem a presente sessão trazem novamente à tona as dinâmicas de formação de grupo. Desde o advento do termo "vegan", a formação de uma identidade de grupo para seus praticantes trouxe junto a alteridade, a diferenciação e enaltecimento das características que faziam do outro algo homogeneamente diferente de si (Galinkin \& Zauli, 2011). Os aproximadamente 5 milhões de veganos brasileiros, portanto, buscam o conforto psicológico do pertencimento social (Forsyth \& Burnette, 2010; Hornsey \& Jetten, 2004) frente a 195 milhões de brasileiros que, ao ter contato com as normas e ideais desse grupo, constroem representações sociais sobre o que é ser vegano. Essas representações, como pode ser observado na análise das evocações dos não veganos, é carregada de preconceitos, uma vez que nas periferias próximas e no núcleo central da análise estão termos como "difícil", "chato", "radical" e "extremista". Ainda que não estejam carregadas de hostilidade, como é observado em outros casos de discriminação social contra minorias, como a homofobia, misoginia, ou racismo, algumas menções sobre aspectos da alimentação vegana possuem caráter pejorativo, como "soja", "salada" e "tofu", de acordo com o que é verificável no Anexo 3, composto por imagens coletadas durante a abordagem aos não veganos no decorrer do presente estudo.

Inicialmente, porém, buscou-se avaliar se os veganos, ao se considerarem um grupo, teriam representações sociais construídas sobre si próprios. Os dados encontrados na análise das evocações, bem como no grupo focal, sugerem que esses indivíduos ancoram a compreensão do que é ser vegano em crenças de autotranscendência humana ("amor", “compaixão", "ética”, "liberdade”) como caminho para um mundo igualitário, bem como em valores ligados à espiritualidade e religião. Partindo de conceitos semelhantes aos de movimentos ambientalistas, o grupo 
vegano se porta socialmente como uma minoria ativa nômica heterodoxa, já que conceitualmente propõe normas contrastantes com o status quo. Assim, de acordo com as teorias de Moscovici - das representações sociais e das minorias ativas - (1961, 1976, 1996, 2003), o grupo dos veganos se caracteriza e se diferencia por representações sociais positivas sobre si e se baseia nas diferenças em relação aos não veganos para estabelecer e reafirmar sua identidade, além de se caracterizar como minoria ativa. Além disso, cabe ressaltar a importância das novas formas de interpretar movimentos sociais, focadas na construção cotidiana do indivíduo ativista (Chatterton \& Pickerill, 2010; Véron, 2016), uma vez que esta abordagem contempla a estruturação social do mundo pós-redes sociais, onde grande parte da conscientização já não mais é feita com base em ações episódicas e públicas. Não é diferente ao movimento vegano, uma vez que as normas dessa minoria ativa predispõem comportamentos diários que, invariavelmente, tangem e, muitas vezes, conflitam com o comportamento da maioria dominante.

Por outro lado, os não veganos também construíram suas representações sociais que, apesar de haver indícios de serem construções recentes, acompanham os achados do presente estudo sobre o caráter político e ético - ou seja, para além do caráter dietético - do veganismo apenas ter sido posto em foco nos últimos anos. Essas representações, como já dito, estão impregnadas, em seu núcleo representacional, de sua ancoragem na dieta vegetariana e trazem em suas periferias termos pejorativos que tornam o indivíduo vegano homogeneamente diferente e distante - reforçando a identidade, protegendo os não veganos de entrar em dissonância cognitiva e justificando sua ausência neste grupo. Apesar disso, há nas periferias das representações de não veganos alguns dos elementos que formaram o núcleo da representação dos veganos (“amor", “compaixão", "ética", "respeito"), sugerindo que a representação está em 
transformação, que os valores nucleares do veganismo para veganos estão começando a se tornar parte da representação dos não veganos. Esse pode ser um indício de que o comportamento ativo vegano está sendo efetivo em seu propósito de adaptação das normas na busca por inclusão, como prediz a teoria das minorias ativas, alcançando assim, a simpatia dos não veganos com a causa vegana.

Da mesma forma, nas periferias mais distantes das representações sociais dos veganos encontram-se elementos que denotam que o contato com os não veganos é permeado por contextos de enfrentamento ("luta", "ativismo", "batalha"), sugerindo que a recente politização mais generalizada do movimento social vegano está se inserindo também na experiência social dos não veganos, pois esta é uma região que reflete as trocas com o exogrupo. Apesar disso, boa parte das representações sociais encontradas na análise das evocações e do grupo focal indicam que ainda é muito presente na experiência social dos veganos, elementos que classificariam o veganismo como um estilo de vida, ainda muito focado apenas nas diferenças alimentares e pouco direcionado de fato à causa animal.

Estudos que sugerem o fim da distinção entre estilo de vida e movimento social (Maxey, 1999; Melucci, 1985; Scott, 2000; Véron, 2016) são recentes e podem ser o caminho a seguir para interpretar qualquer minoria social, pois o contexto privado não deve ser isolado do social como universos independentes. O ser social é construído a partir de suas determinações evolutivas, históricas, culturais e sociais. Estão envolvidos nesse processo de construção, portanto, tanto o ambiente familiar, quanto o social, quanto o individual, pois cada um pode ser tanto agente, quanto paciente de sua própria realidade. A compreensão da realidade, dos propósitos e do conjunto de regras pelos quais as pessoas se identificam com um grupo passa por esse filtro, através do qual significam seu "lugar no mundo". Assim, restringir a interpretação do movimento 
vegano como estilo de vida ou não, desconsidera aspectos da realidade atual necessários para se compreender o comportamento humano. Ou seja, é possível que o movimento vegano esteja encontrando um caminho para discutir seu caráter nômico heterodoxo com o exogrupo através de práticas cotidianas, como a alimentação.

Ao se posicionarem socialmente como uma minoria ativa nômica heterodoxa, os veganos trazem o questionamento sobre a manutenção do modo de vida humano em tempos que a discussão sobre a preservação da natureza é impreterível. Órgãos nacionais e internacionais já se mobilizaram para aconselhar que o consumo (e, portanto, a produção) de produtos animais seja reduzido (Carus, 2015; Ministério da Saúde. Secretaria de Atenção à Saúde. Departamento de Atenção Básica., 2014). A pressão por mudança de comportamento coloca a identidade dos indivíduos em cheque (Branscombe et al., 1999) e surgem mecanismos de defesa para protegê-los da dissonância cognitiva.

A quase ausência de termos abertamente depreciativos e hostis contra o veganismo ou seus seguidores nas evocações de não veganos pode sugerir que, por ter inserção recente na cultura brasileira, os respondentes ainda tenham pouca informação sobre o que vem a ser o veganismo, ancorando-o como uma "dieta saudável, porém restritiva demais”, ao invés de um movimento que visa a abolição da exploração animal. Por outro lado, pode ser uma decorrência da desejabilidade social, que incorre no mascaramento da atitude e poderia resultar no aparente abrandamento do preconceito contra veganos.

Uma terceira hipótese decorre do material coletado durante a abordagem aos participantes (Anexo 3). Considerando as formas de depreciação do veganismo que vem sendo utilizadas em propagandas (muitas vezes apelando para reforços da masculinidade inerente ao consumo de carne, por exemplo), em comentários e imagens 
compartilhadas em redes sociais, e nos comportamentos de recusa em participar da pesquisa, a representação social negativa e hostil contra o veganismo pode estar localizada na zona muda das representações sociais. Estudos posteriores que investigassem esse aspecto podem ser bastante elucidativos quanto às motivações por trás desse tipo de comportamento depreciativo.

Entretanto, cabe ressaltar que o processo de marginalização social e as consequências psicológicas da discriminação não necessariamente dependem da hostilidade advinda do exogrupo. A abordagem oferecida pela teoria das minorias ativas, apesar de ainda pouco utilizada, representa uma forma bastante atual de se interpretar a ação minoritária de grupos marginalizados. Buscar interpretar o comportamento do outro como uma tentativa de integração e inclusão, de ser corretamente compreendido e como um esforço para que não se estabeleçam contrastes e, consequentemente, dissonâncias, pode ser uma forma positiva de lidar com as diferenças interpessoais e intergrupais na atualidade. 


\section{REFERÊNCIAS}

Abric, J.-C. (1976). A structural approach to social representations. In K. Deaux \& G. Philog (Orgs.), Representations of the social: Bridging theoretical traditions (p. 42-47). Malden: Blackwell Publishing.

Abric, J.-C. (2005). A zona muda das representações sociais. In D. C. de Oliveira \& P. H. F. Campos (Orgs.), Representações sociais: uma teoria sem fronteiras (p. 251). Rio de Janeiro: Museu da República Editora.

Adams, C. J. (2015). Política sexual da carne: A relação entre o carnivorismo e a dominância masculina. Alaúde.

Adamson, M. W. (2004). Food in medieval times. Westport, Conn.: Greenwood Press.

Animal Liberation Front. (n.d.). Mission Statement. Recuperado 28 de outubro de 2016, de http://www.animalliberationfront.com/ALFront/mission_statement.htm

Argolo, T. C. (2008). Veganismo Como Desobediência Civil. Recuperado de http://www.abolicionismoanimal.org.br/artigos/veganismocomodesobedinciacivi 1.pdf

Asch, S. E. (1951). Effects of group pressure upon the modification and distortion of judgments. In Groups, leadership and men; research in human relations (p. 177-190). Oxford, England: Carnegie Press.

Backes, D. S., Colomé, J. S., Erdmann, R. H., \& Lunardi, V. L. (2011). Grupo focal como técnica de coleta e análise de dados em pesquisas qualitativas. $O$ mundo da saúde, 35(4), 438-442.

Bardin, L. (1977). Análise de conteúdo. Lisboa: Edições 70.

Barros, L. T. de. (2015). Representações sociais da homossexualidade no ambiente de trabalho : um estudo da zona muda (Dissertação (mestrado)). Recuperado de http://repositorio.unb.br/handle/10482/18063 
Berndsen, M., \& Pligt, J. van der. (2004). Ambivalence towards meat. Appetite, 42(1), 71-78. https://doi.org/10.1016/S0195-6663(03)00119-3

Boyd, M. J. (1936). Porphyry, De Abstinentia I 7-12. The Classical Quarterly, 30(3-4), 188. https://doi.org/10.1017/S0009838800013847

Branscombe, N. R., Ellemers, N., Spears, R., \& Doosje, B. (1999). The context and content of social identity threat. In N. Ellemers, R. Spears, \& B. Doosje (Orgs.), Social identity: Context, commitment, content (p. 35-58). Oxford, England: Blackwell Science.

Bratanova, B., Loughnan, S., \& Bastian, B. (2011). The effect of categorization as food on the perceived moral standing of animals. Appetite, 57(1), 193-196. https://doi.org/10.1016/j.appet.2011.04.020

Brügger, P. (2009). Nós e os outros animais: Especismo, Veganismo e Educação Ambiental. Linhas Críticas, 15(29), 197-214.

Buech, J. (2015). Veggie sweets go mainstream in Germany | Mintel.com. Recuperado 21 de novembro de 2016, de http://www.mintel.com/blog/food-marketnews/veggie-sweets-go-mainstream-in-germany

Camargo, B. V., \& Justo, A. M. (2013). Tutorial para uso do software de análise textual IRAMUTEQ.

Campbell, T. C., \& Campbell, T. M. (2006). The China study: the most comprehensive study of nutrition ever conducted and the startling implications for diet, weight loss and long-term health (1. paperback ed). Dallas, Tex: Benbella Books.

Cao, Y., \& Just, D. R. (2010). Cognitive Dissonance under Food-Borne Risk: A Lab Experiment. Agriculture and Agricultural Science Procedia, 1, 364-371. https://doi.org/10.1016/j.aaspro.2010.09.045 
Capotorti, F. (1991). Study on the rights of persons belonging to ethnic, religious, and linguistic minorities. New York: United Nations.

Carlin, M., \& Rosenthal, J. T. (Orgs.). (1998). Food and eating in medieval Europe. London ; Rio Grande, Ohio: Hambledon Press.

Carus, F. (2015, julho 23). UN urges global move to meat and dairy-free diet. Recuperado de http://www.theguardian.com/environment/2010/jun/02/unreport-meat-free-diet

Castro, A., Papaleo Koelzer, L., Vizeu Camargo, B., \& Barbará S. Bousfield, A. (2014). Representações sociais na internet sobre cotas para negros em universidades federais. Cadernos de Pesquisa Interdisciplinar em Ciências Humanas, 15(106), 202. https://doi.org/10.5007/1984-8951.2014v15n106p202

Chapagain, A. K., \& Hoekstra, A. Y. (2008). The global component of freshwater demand and supply: an assessment of virtual water flows between nations as a result of trade in agricultural and industrial products. Water International, 33(1), 19-32. https://doi.org/10.1080/02508060801927812

Chatterton, P., \& Pickerill, J. (2010). Everyday activism and transitions towards postcapitalist worlds. Transactions of the Institute of British Geographers, 35(4), 475-490. https://doi.org/10.1111/j.1475-5661.2010.00396.x

Chaves, L. (2012). Mapa Veg. Recuperado 10 de agosto de 2015, de http://www.mapaveg.com.br

Cheng, Z. (2007). Greens Are Good For You. Recuperado 21 de novembro de 2016, de http://taiwantoday.tw/ct.asp?xItem $=\&$ ctNode $=416 \& m p=9$

Cohen, T. (2015). In the land of milk and honey, Israelis turn vegan. Reuters. Recuperado de http://www.reuters.com/article/us-israel-food-veganidUSKCNOPV1H020150721 
Companhia Melhoramentos de São Paulo (Org.). (2015). Ativismo. Michaelis Dicionário Brasileiro da Língua Portuguesa. São Paulo: Editora Melhoramentos. Recuperado de http://michaelis.uol.com.br/busca? $\mathrm{r}=0 \& \mathrm{f}=0 \& \mathrm{t}=0 \&$ palavra=ativismo

Confederação da Agricultura e Pecuária do Brasil. (2016). Brasil pode se tornar o maior produtor de carne bovina do mundo. Recuperado 10 de janeiro de 2017 , de http://www.cnabrasil.org.br/noticias/brasil-pode-se-tornar-o-maior-produtor-decarne-bovina-do-mundo

Costa, A. A. A. (2005). O movimento feminista no Brasil: Dinâmicas de uma intervenção política. Revista Gênero, 5(2), 1-20.

Del Prette, A. (2012). Teoria das Minorias Ativas: Pressupostos, Conceitos e Desenvolvimento. Psicologia: Teoria e Pesquisa, 11(2), 145-153.

Desaulniers, E. (2015, janeiro 30). Le végétarisme et ses ennemis : entrevue avec Renan Larue. Recuperado de https://penseravantdouvrirlabouche.com/2015/01/30/levegetarisme-et-ses-ennemis-entrevue-avec-renan-larue/

Dreezens, E., Martijn, C., Tenbült, P., Kok, G., \& de Vries, N. K. (2005). Food and values: an examination of values underlying attitudes toward genetically modified- and organically grown food products. Appetite, 44(1), 115-122. https://doi.org/10.1016/j.appet.2004.07.003

Duberman, M. B. (1991). About time: exploring the gay past (Rev. and expanded ed). New York, N.Y., U.S.A: Meridian.

Dunn, S., \& Rowbotham, S. (1989). The Past Is before Us: Feminism in Action Since the 1960s. Feminist Review, (33), 93. https://doi.org/10.2307/1395216

Durkheim, E. (1898). Représentations Individuelles et Représentations Collectives. Revue de Métaphysique et de Morale, 6(3), 273-302. 
Esteves, L. O., \& Galinkin, A. L. (2017). “Amar independe de espécie”:

Autorrepresentações do movimento social vegano brasileiro. Unpublished manuscript, Universidade de Brasília, Brasília, DF.

Ferrigno, M. V. (2012). Veganismo e libertação animal : um estudo etnográfico

(Dissertação de mestrado). Unicamp, Campinas. Recuperado de http://unicamp.sibi.usp.br/xmlui/handle/SBURI/36575

Fiske, S. T., \& Taylor, S. E. (1984). Social cognition. Reading, Mass: Addison-Wesley Pub. Co.

Fiske, S. T., \& Taylor, S. E. (1991). Social cognition (2nd ed). New York: McGrawHill.

Flandrin, J.-L., Montanari, M., Machado, L. V., \& Teixeira, G. J. de F. (1998). História da alimentação. São Paulo: Estação Liberdade.

Fontenele-Mourão, T. M. (2006). Mulheres no topo de carreira: flexibilidade e persistência. Secretaria Especial de Políticas para as Mulheres.

Forsyth, D. R., \& Burnette, J. L. (2010). Group Processes. In R. F. Baumeister \& E. J. Finkel (Orgs.), Advanced social psychology: the state of the science (p. 495534). Oxford; New York: Oxford University Press.

Francione, G. L. (1996). Rain without thunder: the ideology of the animal rights movement. Philadelphia, Pa: Temple University Press.

Friedman, M. (1996). A positive approach to organized consumer action: The ?buycott? as an alternative to the boycott. Journal of Consumer Policy, 19(4), 439-451. https://doi.org/10.1007/BF00411502

Galinkin, A. L., \& Zauli, A. (2011). Identidade Social e Alteridade. In C. V. Torres \& E. R. Neiva (Orgs.), Psicologia social: principais temas e vertentes (p. 253262). Porto Alegre: Artmed. 
Gelfer, J. (2013). Meat and Masculinity in Men's Ministries. The Journal of Men's Studies, 21(1), 78-91. https://doi.org/10.3149/jms.2101.78

Goffman, E. (1988). Estigma: notas sobre a manipulação da identidade deteriorada. Rio de Janeiro, RJ: LTC.

Gohn, M. da G. M. (2003). Movimentos sociais no início do século XXI: antigos e novos atores sociais. Petrópolis, RJ: Editora Vozes.

Gomes, M. A. B., Silva, M. B. da, \& Carmo, Q. S. do. (2010). Vegetarianismo X Onivorismo: Uma Perspectiva Da Propaganda Ideológica. In Trabalhos aprovados Divisões Temáticas - Intercom Centro-Oeste 2010. Goiânia. Recuperado de http://www.intercom.org.br/papers/regionais/centrooeste2010/resumos/R210234-1.pdf

Greenpeace. (2010). Missão e Valores. Recuperado 28 de outubro de 2016, de http://www.greenpeace.org/brasil/pt/quemsomos/Missao-e-Valores-/

Haenfler, R., Johnson, B., \& Jones, E. (2012). Lifestyle Movements: Exploring the Intersection of Lifestyle and Social Movements. Social Movement Studies, 11(1), 1-20. https://doi.org/10.1080/14742837.2012.640535

Haines, H. H. (1984). Black Radicalization and the Funding of Civil Rights: 1957-1970. Social Problems, 32(1), 31-43. https://doi.org/10.2307/800260

Harris, M. (1999). Bueno para comer: enigmas de alimentación y cultura. Madrid: Alianza.

Hart, D., \& Sussman, R. W. (2005). Man the hunted: primates, predators, and human evolution. New York: Westview Press.

Hollander, E. P. (1965). Leaders, Groups and Influence. Oxford, UK: Oxford University Press. 
Homans, G. C. (1974). Social behavior; its elementary forms (Rev. ed). New York: Harcourt, Brace, Jovanovich.

Hornsey, M. J., \& Jetten, J. (2004). The individual within the group: balancing the need to belong with the need to be different. Personality and Social Psychology Review: An Official Journal of the Society for Personality and Social Psychology, Inc, 8(3), 248-264. https://doi.org/10.1207/s15327957pspr0803_2

IBOPE. (2012). Dia Mundial do Vegetarianismo: 8\% da população brasileira afirma ser adepta do estilo. Recuperado 23 de julho de 2015, de http://www.ibope.com.br/pt-br/noticias/paginas/dia-mundial-do-vegetarianismo8-da-populacao-brasileira-afirma-ser-adepta-ao-estilo.aspx

Instituto Brasileiro de Geografia e Estatística - IBGE. (2015a). Acesso à internet e à televisão e posse de telefone móvel celular para uso pessoal : 2013. Rio de Janeiro: IBGE. Recuperado de http://biblioteca.ibge.gov.br/visualizacao/livros/liv93373.pdf

Instituto Brasileiro de Geografia e Estatística - IBGE. (2015b). Pesquisa Nacional por Amostra de Domicílios : síntese de indicadores 2014. Rio de Janeiro: IBGE. Recuperado de http://biblioteca.ibge.gov.br/visualizacao/livros/liv94935.pdf

Jones, E. E., \& Gerard, H. B. (1967). Foundations of social psychology. New York: Wiley.

Joy, M. (2010). Why we love dogs, eat pigs, and wear cows: an introduction to carnism: the belief system that enables us to eat some animals and not others. San Francisco: Conari Press.

Kirjner, D., \& Kemmerer, L. (2015). Conflict and accord: A critical review of Theory and Methods for Earth and Animal Advocacy. In L. Kemmerer (Org.), Animals 
and the environment: advocacy, activism, and the quest for common ground (p. 15-37). London ; New York: Routledge, Taylor \& Francis Group.

Kronberger, N., \& Wagner, W. (2002). Palavras-chave em contexto: análise estatística de textos. In M. W. Bauer (Org.), Facebook Twitter Google Plus Pesquisa Qualitativa com Texto , Imagem e Som. Petrópolis, RJ: Vozes.

Kunst, J. R., \& Hohle, S. M. (2016). Meat eaters by dissociation: How we present, prepare and talk about meat increases willingness to eat meat by reducing empathy and disgust. Appetite, 105, 758-774. https://doi.org/10.1016/j.appet.2016.07.009

Le Bon, G. (1895). Psicologia das Multidões. Lisboa, 1980: Delraux.

Le Bon, G. (1897). The crowd: a study of the popular mind. Fischer.

Lopes, G. L. "Nassar”Gouvêa, \& Arruda, R. P. (2014). Veganismo abolicionista e práticas culturais. Revista Brasileira de Direito Animal, 9(17). https://doi.org/10.9771/rbda.v9i17.12996

Loughnan, S., Haslam, N., \& Bastian, B. (2010). The role of meat consumption in the denial of moral status and mind to meat animals. Appetite, 55(1), 156-159. https://doi.org/10.1016/j.appet.2010.05.043

Macrae, C. N., \& Bodenhausen, G. V. (2000). Social Cognition: Thinking Categorically about Others. Annual Review of Psychology, 51(1), 93-120. https://doi.org/10.1146/annurev.psych.51.1.93

Marková, I. (2003). Les focus groups. In S. Moscovici \& F. Buschini (Orgs.), Les méthodes des sciences humaines (p. 221-241). Paris: PUF.

Martins, S. S., Igreja, A. C. M., Bini, D. L. de C., Perez, L. H., \& Rocha, M. B. (2011). Poder de Compra do Salário-mínimo em Termos das Carnes Bovina, Suína e de Frango, no Período de 1970 a 2010. Análises e Indicadores do Agronegócio, 
6(6). Recuperado de

http://www.iea.sp.gov.br/out/LerTexto.php?codTexto=12150

Maxey, I. (1999). Beyond boundaries? Activism, academia, reflexivity and research. Area, 31(3), 199-208. https://doi.org/10.1111/j.1475-4762.1999.tb00084.x

Melucci, A. (1985). The Symbolic Challenge of Contemporary Movements. Social Research, 52(4), 789-816.

Ministério da Saúde. Secretaria de Atenção à Saúde. Departamento de Atenção Básica. (2014). Guia alimentar para a população brasileira (2ª). Brasília: Ministério da Saúde. Recuperado de http://189.28.128.100/dab/docs/portaldab/publicacoes/guia_alimentar_populacao _brasileira_impressao.pdf

Morgan, R. (2016). The slow but steady rise of vegetarianism in Australia. Recuperado 21 de novembro de 2016, de http://www.roymorgan.com/findings/vegetarianisms-slow-but-steady-rise-inaustralia-201608151105

Moscovici, S. (1961). La psychanalyse, son image et son public. Paris: Presses Univ. de France.

Moscovici, S. (1976). Social influence and social change. London; New York: published in cooperation with European Association of Experimental Social Psychology by Academic Press.

Moscovici, S. (1996). Psychologie des minorités actives. Paris: Presses universitaires de France.

Moscovici, S. (2003). Representações sociais: investigações em psicologia social. Petrópolis, RJ: Vozes. 
Moscovici, S., \& Néve, P. (1973). Studies on polarization of judgments: III. Majorities, minorities and social judgments. European Journal of Social Psychology, 3(4), 479-484. https://doi.org/10.1002/ejsp.2420030410

Mugny, G., \& Papastamou, S. (1982). The power of minorities. London ; New York: Published in cooperation with European Association of Experimental Social Psychology by Academic Press.

Nascimento, A. R. A. do, \& Menandro, P. R. M. (2006). Análise lexical e análise de conteúdo: uma proposta de utilização conjugada. Revista Estudos e Pesquisas em Psicologia, 6(2), 72-88.

Nascimento, J. B. do, \& Silva, V. G. da. (2012). Veganismo: defesa de uma ética na relação entre humanos e animais. Caos - Revista Eletrônica de Ciências Sociais/UFPB, (21), 73-90.

National Research Council, Committee on Diet, Nutrition, and Cancer, Commission on Life Sciences, \& Division on Earth and Life Studies. (1982). Diet, Nutrition, and Cancer. Washington, D.C.: National Academies Press. Recuperado de http://www.nap.edu/catalog/371

Nemeth, C., Swedlund, M., \& Kanki, B. (1974). Patterning of the minority's responses and their influence on the majority. European Journal of Social Psychology, 4(1), 53-64. https://doi.org/10.1002/ejsp.2420040104

Nunes, E. L. M. (2010). Vegetarianismo além da dieta: ativismo vegano em São Paulo (Dissertação de mestrado). PUC-SP, São Paulo. Recuperado de http://tede2.pucsp.br/tede/handle/handle/4199

Oliveira, L. (2013). Justificativas para o Vegetarianismo em Porfírio de Tiro. In Actas del XIII Encuentro Internacional de Estudios Clásicos (p. 39-52). Chile: Centro de Estudios Clásicos Giuseppina Grammatico Amari. Recuperado de 
http://s3.amazonaws.com/academia.edu.documents/37211228/Loraine-OliveiraJustificativas.pdf?AWSAccessKeyId=AKIAJ56TQJRTWSMTNPEA\&Expires= 1472539625\&Signature=3dgAngJFjo36u5qSZVCaD5yC6xQ\%3D\&responsecontentdisposition=inline \%3B\%20filename\%3DJustificativas_para_o_Vegetarianismo_ em.pdf

Park, B., \& Judd, C. M. (2005). Rethinking the Link Between Categorization and Prejudice Within the Social Cognition Perspective. Personality and Social Psychology Review, 9(2), 108-130. https://doi.org/10.1207/s15327957pspr0902_2

Pazzini, B. (2014). O veganismo como prática de justiça e igualdade: perspectivas descoloniais pela consagração de um novo direito. In Anais del Congreso de Estudios Poscoloniales. Buenos Aires. Recuperado de http://repositorio.furg.br/handle/1/5202

PETA. (n.d.). About PETA. Recuperado de http://www.peta.org/about-peta/

Phelps, N. (2007). The longest struggle: animal advocacy from Pythagoras to PETA. New York: Lantern Books.

Piazza, J., Ruby, M. B., Loughnan, S., Luong, M., Kulik, J., Watkins, H. M., \& Seigerman, M. (2015). Rationalizing meat consumption. The 4Ns. Appetite, 91, 114-128. https://doi.org/10.1016/j.appet.2015.04.011

Pomeranz, L. (1977). A demanda de produtos alimentícios industrializados no Brasil. Revista de Administração de Empresas, 17(6), 81-101. https://doi.org/10.1590/S0034-75901977000600006 
Radnitz, C., Beezhold, B., \& DiMatteo, J. (2015). Investigation of lifestyle choices of individuals following a vegan diet for health and ethical reasons. Appetite, 90, 31-36. https://doi.org/10.1016/j.appet.2015.02.026

Redaktion. (2013). “The vegetarian lifestyle is a long-term development”. Recuperado 21 de novembro de 2016, de http://organic-market.info/news-in-brief-andreports-article/vegetarian.html

Regan, T. (1988). The case for animal rights. London: Routledge.

Reinert, M. (1998). Alceste: Analyse de données textuelles. Manuel d'utilisteur. Recuperado de https://www.scienceopen.com/document?vid=1e4516b5-2a43486b-976a-894e9f851872

Román, D., \& Vilaplana, E. (2002). La diética ética: ética y diétetica del veganismo. Alicante: Román Molto, David.

Rothgerber, H. (2013). Real men don't eat (vegetable) quiche: Masculinity and the justification of meat consumption. Psychology of Men \& Masculinity, 14(4), 363-375. https://doi.org/10.1037/a0030379

Sá, C. P. de. (1998). A construção do objeto de pesquisa em representações Sociais. Rio de Janeiro: EDUERJ.

Sá, C. P. de, Vetere, R., Castro, R. V. de, Oliveira, D. C. de, \& Carvalho, R. V. C. de. (2009). A memória histórica do regime militar ao longo de três gerações no Rio de Janeiro: sua estrutura representacional. Estud. psicol. (Campinas), 26(2), $159-171$.

Santana, H. J. de, Santana, L. R., \& Trajano, T. (2015, julho 23). Veganismo como ação política. 
Santos, M. de F. de S., \& Almeida, L. M. de. (2005). Diálogos com a teoria da representação social. Recife [Brazil: Editora Universitária UFPE, Universidade Federal de Pernambuco : EDUFAL.

Schiavazzi, V. (2015). Addio carne e pesce: in aumento il popolo dei vegetariani e vegani in Italia. Recuperado 21 de novembro de 2016, de http://www.repubblica.it/salute/2015/10/02/news/e_tu_quanto_sei_vegano_$124177488 /$

Scott, J. C. (2000). Weapons of the weak: everyday forms of peasant resistance (Nachdr.). New Haven: Yale Univ. Press.

Secord, P. F., \& Backman, C. W. (1974). Social psychology (2d ed). New York: McGraw-Hill.

Singer, P. (1977). Animal liberation: [a new ethics for our treatment of animals. New York: Avon Books.

Sobal, J. (2005). Men, meat, and marriage: models of masculinity. Food and Foodways, 13(1-2), 135-158. https://doi.org/10.1080/07409710590915409

Souza, C. C. de. (2016). \#Govegan : veganismo, vegetarianismo e dever moral nos enquadramentos da mobilização pelos direitos animais no Brasil. Universidade Federal do Paraná, Curitiba. Recuperado de http://acervodigital.ufpr.br/handle/1884/44259

Spencer, C. (1996). The heretic's feast: a history of vegetarianism (1st pbk. ed). Hanover, NH: University Press of New England.

Tarde, G. de. (1890). Les lois de l'imitation. Chicoutimi: J.-M. Tremblay. Recuperado de http://www.uqac.ca/zone30/Classiques_des_sciences_sociales/classiques/tarde_ gabriel/lois_imitation/lois_imitation.html 
Tarde, G. de. (1901). L'opinion et la foule. Chicoutimi: J.-M. Tremblay. Recuperado de http://www.uqac.ca/zone30/Classiques_des_sciences_sociales/classiques/tarde_ gabriel/opinion_et_la_foule/opinion_et_foule.html

The Local/og. (2014). One in ten Swedes is vegetarian: survey. Recuperado 21 de novembro de 2016, de http://www.thelocal.se/20140321/one-in-ten-swedes-isvegetarian-survey

The Times of India. (2014). At 99\%, Telangana has maximum non-vegetarians in the country - Times of India. Recuperado 21 de novembro de 2016, de http://timesofindia.indiatimes.com/city/hyderabad/At-99-Telangana-hasmaximum-non-vegetarians-in-the-country/articleshow/52697572.cms

Tobin, J. (1999). A performance da masculinidade portenha no churrasco. Cadernos Pagu, O(12), 301-329.

Torres, C. V., \& Allen, M. W. (2006). Food Symbolism and Consumer Choice in Brazil. Latin American Advances in Consumer Research - Association for Consumer Research, 1, 180-185.

Trigueiro, A. (2013). Consumo, ética e natureza: o veganismo e as interfaces de uma política de vida. Revista Internacional Interdisciplinar INTERthesis, 10(1). https://doi.org/10.5007/1807-1384.2013v10n1p237

Twine, R. (2014). Vegan Killjoys at the Table_Contesting Happiness and Negotiating Relationships with Food Practices. Societies, 4(4), 623-639. https://doi.org/10.3390/soc4040623

Vegetarismus.ch. (2007). Wieviele Vegetarier gibt es in der Schweiz: Vegi-Info 2001/1. Recuperado 21 de novembro de 2016, de http://www.vegetarismus.ch/heft/20011/anzahl.htm 
Verein gegen tierfabriken. (2013). Verbreitung der vegetarischen Lebensweise.

Recuperado 21 de novembro de 2016, de http://archiv.veggieplanet.at/warumvegan/tierrechte/Veggie.pdf

Véron, O. (2016). (Extra)Ordinary Activism: Veganism and the Shaping of Hemeratopias. International Journal of Sociology and Social Policy. https://doi.org/10.1108/IJSSP-12-2015-0137

Watson, D. (1965). The Early History of the Vegan Movement. The Vegan, (Winter 1965-6). Recuperado de http://issuu.com/vegan_society/docs/the-vegan-winter1965

Weiszflog, W. (2008). Michaelis: dicionário escolar língua portuguesa (3. ed). São Paulo: Melhoramentos.

WWF Brasil. (n.d.). WWF Brasil - Temas. Recuperado 28 de outubro de 2016, de http://www.wwf.org.br/natureza_brasileira/reducao_de_impactos2/ 
ANEXOS 


\section{Anexo 1 - Termo de Consentimento Livre e Esclarecido}

Você está sendo convidado a participar de uma pesquisa, de responsabilidade de Luiz Otávio Bastos Esteves, aluno de mestrado da Universidade de Brasília - UnB, sob orientação da Prof ${ }^{\mathbf{a}}$ Dra Ana Lúcia Galinkin. O objetivo desta pesquisa é caracterizar a forma como é visto e compreendido o veganismo. Espera-se com esta pesquisa ampliar as discussões de relações sociais minoria-maioria. Assim, gostaria de consultá-lo(a) sobre seu interesse e disponibilidade de cooperar com a pesquisa.

Não existem respostas certas ou erradas. Seu nome não será divulgado, sendo mantido o mais rigoroso sigilo mediante a omissão total de informações que permitam identificálo(a). Os dados provenientes de sua participação na pesquisa ficarão sob a guarda do pesquisador responsável pela pesquisa.

A coleta de dados será realizada por meio de dois breves questionários. É para estes procedimentos que você está sendo convidado(a) a participar. Sua participação na pesquisa não implica em nenhum risco.

Sua participação é voluntária e livre de qualquer remuneração ou benefício. Você é livre para recusar-se a participar, retirar seu consentimento ou interromper sua participação a qualquer momento. A recusa em participar não acarretará em qualquer penalidade ou prejuízo.

Se você tiver qualquer dúvida em relação à pesquisa, você pode me contatar através do e-mail luizobe@gmail.com.

É garantido que os resultados do estudo serão devolvidos aos participantes por meio de feedback por e-mail caso solicitado por meio do endereço fornecido acima, podendo ser publicados posteriormente na comunidade científica.

Sua participação é voluntária e livre de qualquer remuneração ou benefício. Você é livre para recusar-se a participar, retirar seu consentimento ou interromper sua participação a qualquer momento. A recusa em participar não acarretará em qualquer penalidade ou prejuízo.

Ao prosseguir, você concorda com os termos acima e inicia sua participação nesta pesquisa.

Muito obrigado desde já!

Vamos começar? 


\section{Anexo 2 - Questionários}

\section{- QUESTIONÁRIO DE PERFIL SOCIODEMOGRÁFICO -}

Prezado participante,

Leia atentamente o questionário e responda assinalando com um $\mathbf{X}$ a opção dentro da qual você se encaixa, bem como preenchendo os campos cabíveis para cada uma das dez questões a seguir.

ATENÇÃO: Os dados fornecidos no presente questionário são sigilosos e confidenciais, tendo como único objetivo delinear o perfil sociodemográfico dos participantes como um todo.

1. Qual seu sexo biológico?

( ) Feminino

( ) Masculino

2. Com qual gênero você se identifica?

( ) Mulher

( ) Homem

( ) Outro. Qual?

( ) Prefiro não informar

3. Qual a sua faixa de idade?

( ) Menor de 18 anos

( ) Entre 18 e 23 anos

( ) Entre 23 e 28 anos

( ) Entre 28 e 33 anos

( ) Acima de 33 anos

\section{Cidade/UF de origem?}

5. Qual seu grau de escolaridade? (Assinale apenas uma opção, mas preencha todos os campos cabíveis)

( ) Ensino Fundamental incompleto

( ) Outro. Qual?

( ) Ensino Fundamental completo

( ) Ensino Médio incompleto

( ) Ensino Médio completo

( ) Ensino Superior incompleto

( ) Ensino Superior completo. Em qual área?

( ) Pós-graduação / Mestrado /

Doutorado incompleto. Em qual área?

( ) Pós-graduação / Mestrado /

Doutorado completo. Em qual área? 


\section{Qual sua ocupação atual?}

\section{Qual a sua renda pessoal?}

( ) Menos de 1 salário mínimo (Abaixo de $\mathrm{R} \$ 788,00$ )

( ) Entre 1 e 4 salários mínimos (Entre $R \$ 789,00$ e $R \$ 3151,00$ )

( ) Entre 4 e 6 salários mínimos (Entre $R \$ 3152,00$ e $R \$ 4728,00$ )

( ) Acima de 6 salários mínimos (Acima de $R \$ 4729,00$ )

( ) Não possuo renda pessoal. Qual a sua renda familiar?

( ) Menos de 10 salários mínimos (Abaixo de $\mathrm{R} \$ 7880,00$ )

( ) Acima de 10 salários mínimos (Acima de $\mathrm{R} \$ 7881,00$ )

\section{Há quanto tempo é vegan?}

( ) Menos de 6 meses

( ) Entre 6 meses e 1 ano

( ) Entre 1 e 2 anos

( ) Entre 2 e 3 anos

( ) Acima de 4 anos. Quantos anos?

9. Me considero um ativista vegan. (Marque com um $X$ a opção que mais se adequa à sua opinião)

\begin{tabular}{c|c|c|c}
$\begin{array}{c}\text { DISCORDO } \\
\text { PLENAMENTE }\end{array}$ & DISCORDO & CONCORDO & $\begin{array}{c}\text { CONCORDO } \\
\text { PLENAMENTE }\end{array}$ \\
\hline$($ ) & $($ ) & $($ ) & $($ )
\end{tabular}




\section{- QUESTIONÁRIO DE PERFIL SOCIODEMOGRÁFICO -}

Prezado participante,

Leia atentamente o questionário e responda assinalando com um $\mathbf{X}$ a opção dentro da qual você se encaixa, bem como preenchendo os campos cabíveis para cada uma das dez questões a seguir.

ATENÇÃO: Os dados fornecidos no presente questionário são sigilosos e confidenciais, tendo como único objetivo delinear o perfil sociodemográfico dos participantes como um todo.

1. Qual seu sexo biológico?

( ) Feminino

( ) Masculino

2. Com qual gênero você se identifica?

( ) Mulher

( ) Homem

( ) Outro. Qual?

( ) Prefiro não informar

3. Qual a sua faixa de idade?

( ) Menor de 18 anos

( ) Entre 18 e 23 anos

( ) Entre 23 e 28 anos

( ) Entre 28 e 33 anos

( ) Acima de 33 anos

4. Cidade/UF de origem?

5. Qual seu grau de escolaridade? (Assinale apenas uma opção, mas preencha todos os campos cabíveis)

( ) Ensino Fundamental incompleto

( ) Ensino Fundamental completo

( ) Ensino Médio incompleto

( ) Ensino Médio completo

( ) Ensino Superior incompleto

( ) Ensino Superior completo. Em qual área?

( ) Pós-graduação / Mestrado /

Doutorado incompleto. Em qual área?

( ) Pós-graduação / Mestrado /

Doutorado completo. Em qual área?

) Outro. Qual? 
6. Qual sua ocupação atual?

\section{Qual a sua renda pessoal?}

( ) Menos de 1 salário mínimo (Abaixo de $R \$ 788,00$ )

( ) Entre 1 e 4 salários mínimos (Entre $\mathrm{R} \$ 789,00$ e $\mathrm{R} \$ 3151,00$ )

( ) Entre 4 e 6 salários mínimos (Entre $R \$ 3152,00$ e $R \$ 4728,00$ )

( ) Acima de 6 salários mínimos (Acima de $\mathrm{R} \$ 4729,00$ )

( ) Não possuo renda pessoal. Qual a sua renda familiar?

( ) Menos de 10 salários mínimos (Abaixo de $R \$ 7880,00$ )

( ) Acima de 10 salários mínimos (Acima de $R \$ 7881,00$ )

8. Quanto à sua ideologia alimentar, você se considera:
( ) Onívoro
( ) Carnívoro
( ) Vegetariano
( ) Crudívoro
( ) Outro. Especifique: 


\section{- QUESTIONÁRIO DE EVOCAÇÃO DE PALAVRAS -}

Prezado participante,

Você está sendo convidado a participar de uma pesquisa sobre representações sociais acerca do veganismo. É um questionário rápido, levará apenas alguns minutos. Para participar, basta responder às questões a seguir.

1. Quais as primeiras palavras, ou ideias, que the veem à mente sobre ser vegan/veganismo.

1.

2.

3.

4.

5.

2. Entre as palavras ou ideias que você listou, qual (apenas uma) você acha que melhor define o que é ser vegan/veganismo (marcar o número da resposta com um círculo).

3. Explique porque esta palavra melhor define o que é ser vegan/veganismo.

Muito obrigado por sua participação! 
Anexo 3 - Material discriminatório coletado durante a pesquisa

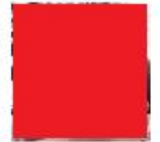

\section{Lucas}

morte aos vegans

Ontem às 10:10 PM · Curtir

Nicholas

morte aos vegans

Ontem às 10:10 PM • Curtir

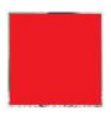

Marcio José

Ateu, evangélico, vegano e crossfiteiro competem pra ver quem enche mais o saco dos outros.

sáb às 4:03 PM • Curtir • It 10 • Responder

\section{Bárbara}

Ninguém aguenta mais vcs vegans

alice

Matheus

Isso só me faz querer comer mais e mais carne pelo reeeesto da vida.

sáb às 4:00 PM - Curtir • It 4 • Responder primeiro
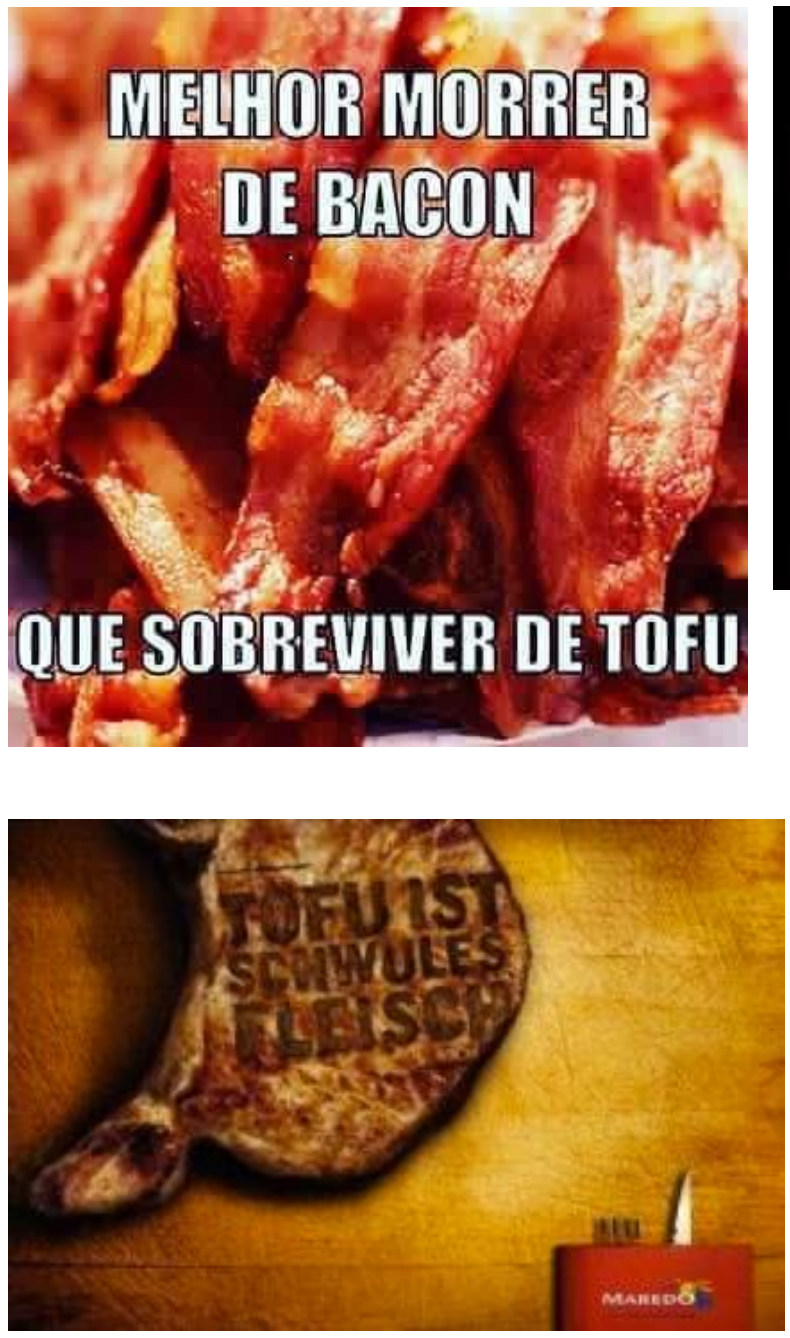

Legenda: Tofu é carne gay.
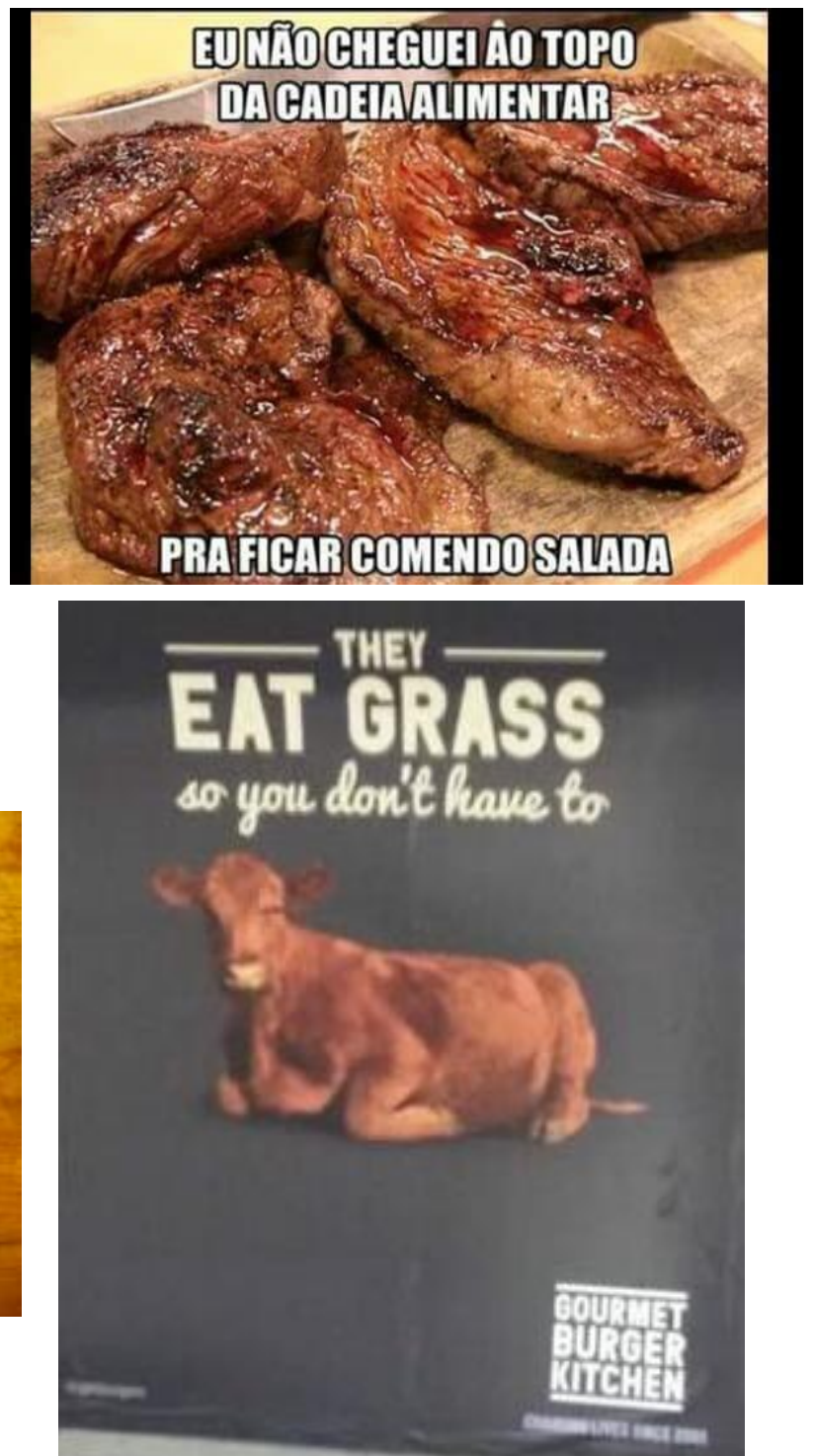

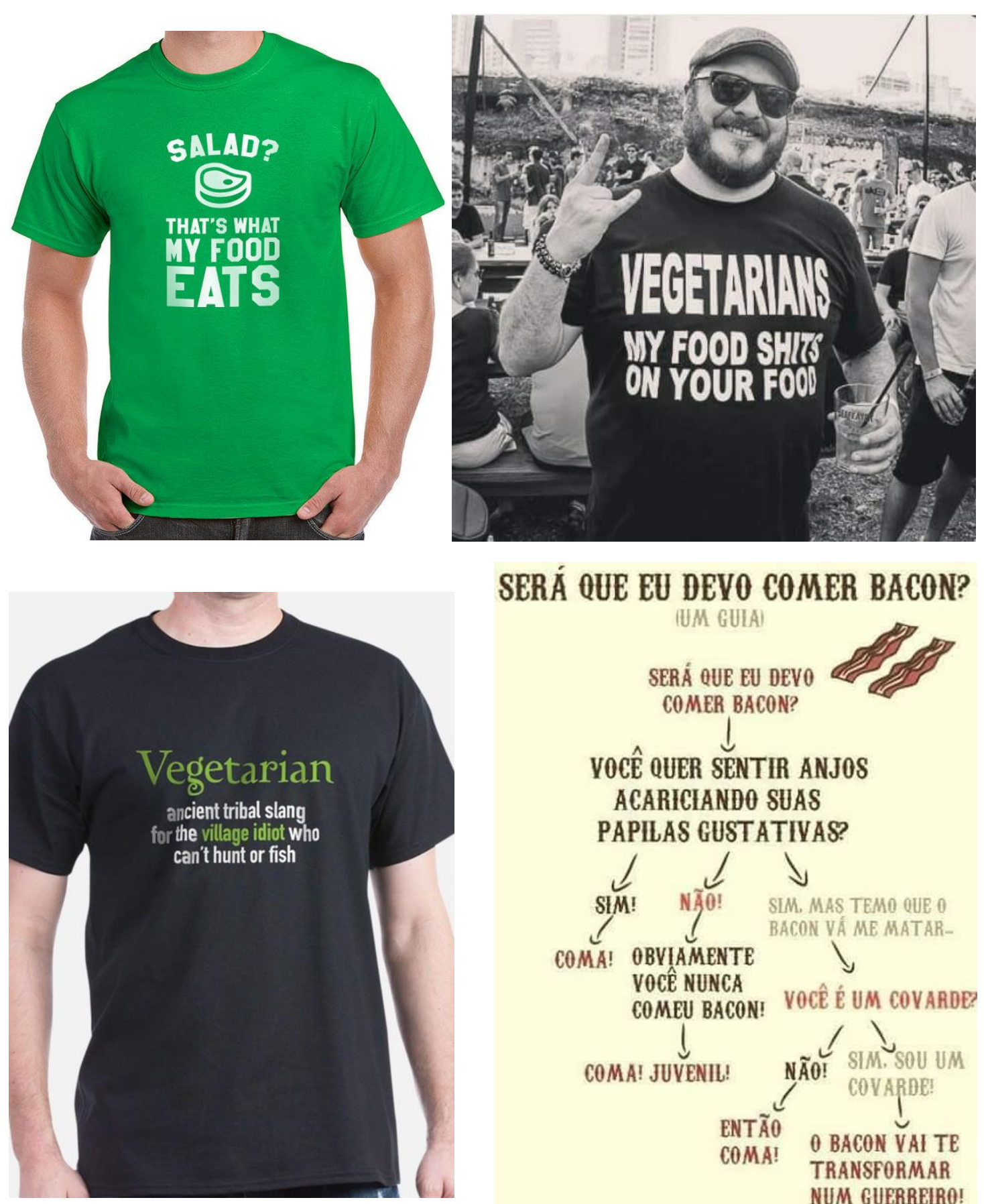

SERÁ QUE EU DEVO COMER BACON?
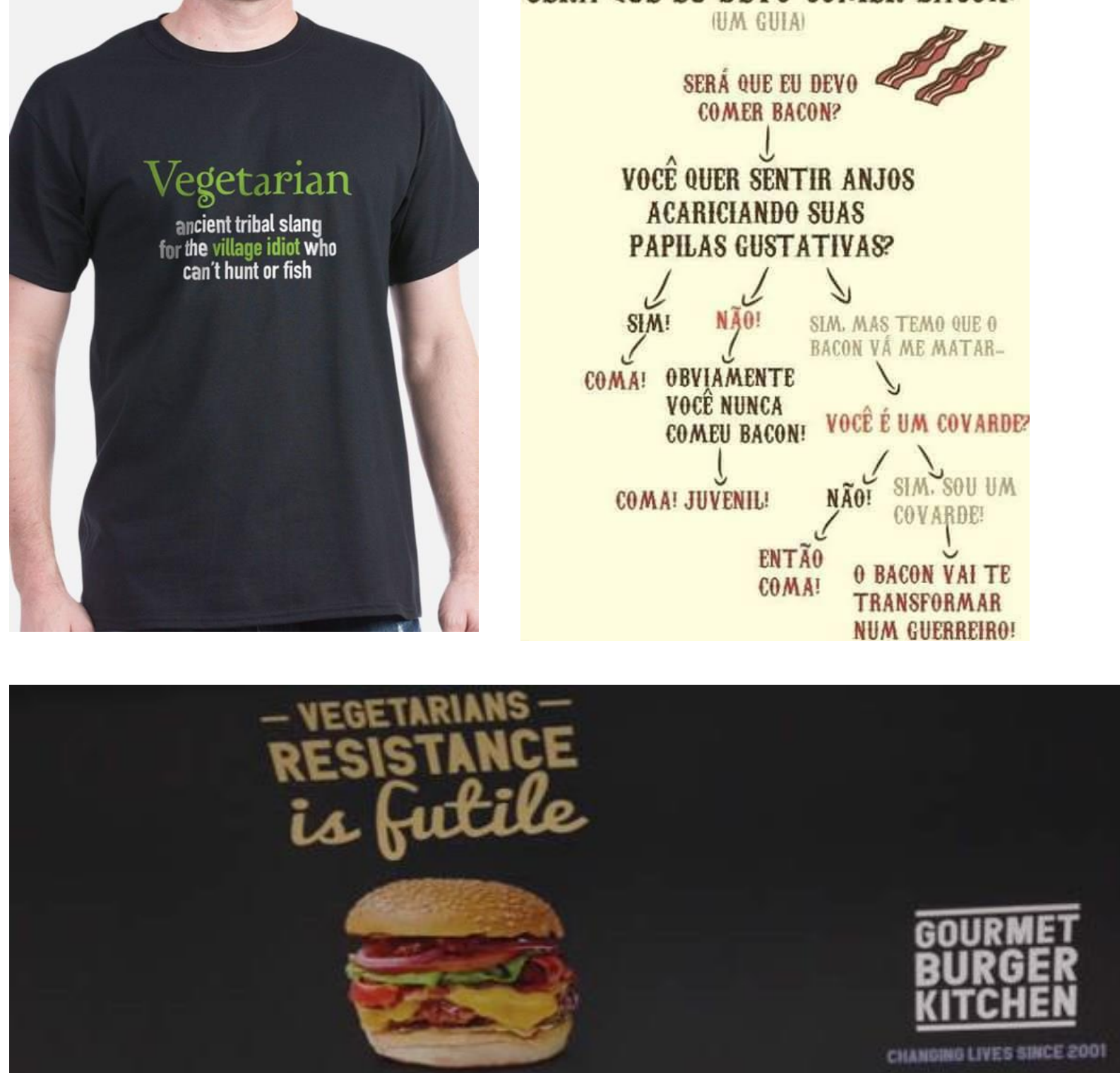